\title{
PARÂMETROS PRODUTIVOS E ATIVIDADE DE FOSFATASE ÁCIDA EM TRÊS GRAMÍNEAS FORRAGEIRAS CULTIVADAS COM DOSES DE FÓSFORO
}

\author{
JOSÉ EDUARDO PEREIRA DA SILVA \\ Engenheiro Agrônomo
}

Orientador: Prof. Dr. Francisco Antonio Monteiro

Dissertação apresentada à Escola Superior de Agricultura "Luiz de Queiroz", da Universidade de São Paulo, para obtenção do título de Mestre em Agronomia, Área de Concentração: Solos e Nutrição de Plantas.

P I RA C I C A B A

Estado de São Paulo - Brasil

Janeiro - 1996 
Dados Internacionais de Catalogação na Publicação (CIP)

DIVISÃO DE BIBLIOTECA E DOCUMENTAÇÂO - Campus "Luỉz de Queiroz"/USP

Silva, José Eduardo Pereira da

Paràmetros produtivos e atividade de fosfatase ácida em três gramineas

forrageiras cultivadas com doses de fósforo / José Eduardo Pereira da

Silva. - - Piracicaba, 1996.

$81 \mathrm{p}$. : il.

Dissertação (mestrado) - E Escola Superior de Agricultura Luiz de Queiroz, 1996.

Bibliografia.

1. Adubaçăo fosfatada 2. Fosfatase ácida em graminea forrageira - Aṭ̣ vidade 3. Fósforo em gramínea forrageira 4. Graminea forrageira - Nutrição 1. Titulo 


\section{PARÂMETROS PRODUTIVOS E ATIVIDADE DE FOSFATASE ÁCIDA EM TRÊS GRAMÍNEAS FORRAGEIRAS CULTIVADAS COM DOSES DE FÓSFORO}

\section{JOSÉ EDUARDO PEREIRA DA SILVA}

Aprovada em: 08.03.1996

Comissão julgadora:

Prof. Dr. FRANCISCO ANTONIO MONTEIRO ESALQ/USP

Dr. HERBERT BARBOSA DE MATTOS IZ/SAA

Prof. Dr. RONALDO IVAN SILVEIRA ESALQ/USP

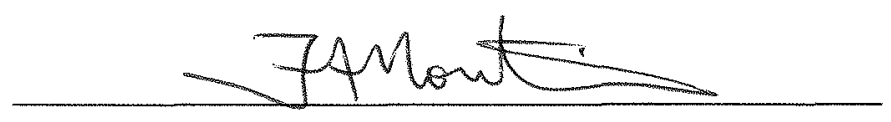

Prof. Dr. Francisco Antonio Monteiro Orientador 
Ao meu pai "in memorian"

A minha mãe e a minha irmã,

\section{OFEREÇO}

A minha esposa FÁTIMA e as

nossas filhas BIANCA e CARLA,

\section{DEDICO.}




\section{AGRADECIMENTOS}

Ao Prof. Dr. Francisco Antonio Monteiro, pela excelente orientação e amizade desenvolvida.

Ao Prof. Dr. Quirino Augusto de Camargo Carmelo, pela amizade e sugestões apresentadas ao trabalho.

Ao Prof. Dr. Antonio Roque Dechen, pela amizade e incentivo que manifestava.

Ao prof. Dr. Luiz Carlos Basso, pelo auxílio prestado para metodologia analítica da atividade de fosfatase ácida e pelas sugestões.

A todos professores do curso de Solos e Nutrição de Plantas pela dedicação e conhecimentos transmitidos.

À amiga Ana Carmelita, pela amizade e ajuda prestada pela realização deste trabalho.

Ao amigo Antonio CarlosVicentin, pelo auxílio na área de informática para a realização do trabalho.

Aos estagiários da área de Nutrição Mineral de Plantas, pela dedicação e amizade.

Aos funcionários do laboratório de Nutrição Mineral de Plantas, pela dedicação e apoio para a realização das análises químicas.

Aos funcionários do Departamento de Solos e Nutrição Plantas, pela dedicação e apoio para a realização do experimento.

A CAPES pelo apoio financeiro e institucional prestado para a realização deste trabalho. 


\section{SUMÁRIO}

RESUMO vii

SUMMARY.

$\mathrm{x}$

1. INTRODUÇÃO

2. REVISÃO DE LITERATURA 03

2.1. Fósforo no solo e na planta 03

2.2. O fósforo e a nutrição de gramíneas forrageiras 04

2.3. Atividade de fosfatase ácida. 07

3. MATERIAL E MÉTODOS 11

3.1. Câmara-de-crescimento 11

3.1.1. Primeiro experimento

3.1.1.1. Condições de instalação e condução do experimento... 11

3.1.1.2. Tratamentos e delineamento experimental.................. 12

3.1.1.3. Coleta do material vegetal......................................... 13

3.1.2. Segundo experimento ........................................................ 14

3.1.2.1. Condições de instalação e condução do experimento... 14

3.1.2.2. Tratamentos e delineamento experimental.................. 15

3.1.2.3. Coleta do material vegetal........................................ 15 


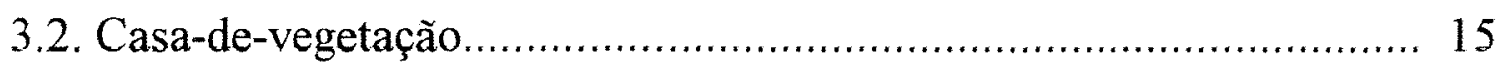

3.2.1. Condições de instalação e condução do experimento.............. 16

3.2.2. Tratamentos e delineamento experimental.............................. 16

3.2.3. Coleta do material vegetal.................................................. 17

3.3. Determinação no material vegetal................................................... 18

3.3.1. Produção de matéria seca da parte aérea................................. 18

3.3.2. Determinação do teor de fósforo no tecido vegetal................. 19

3.3.3. Atividade de fosfatase ácida no tecido foliar......................... 19

3.3.4. Conteúdo de fósforo da parte aérea........................................ 20

3.3.5. Número de perfilhos........................................................ 20

4. RESULTADOS E DISCUSSÃO....................................................... 21

4.1. Câmara-de-crescimento............................................................. 21

4.1.1. Primeiro experimento......................................................... 21

4.1.1.1. Número de perfilhos................................................. 21

4.1.1.2. Produção de matéria seca da parte aérea...................... 23

4.1.1.3. Teor de fósforo no tecido vegetal................................ 25

4.1.1.4. Conteúdo de fósforo da parte aérea............................ 26

4.1.1.5. Atividade de fosfatase ácida no tecido foliar............... 27

4.1.2. Segundo experimento.......................................................... 29

4.1.2.1. Número de perfilhos................................................ 29

4.1.2.2. Produção de matéria seca da parte aérea...................... 32

4.1.2.3. Teor de fósforo da parte aérea................................... 36 
4.1.2.4. Conteúdo de fósforo da parte aérea......................... 41

4.1.2.5. Atividade de fosfatase ácida no tecido foliar.............. 47

4.2. Casa-de-vegetação.............................................................. 53

4.2.1. Primeiro corte ............................................................ 53

4.2.1.1. Número de perfilhos.......................................... 53

4.2.1.2. Produção de matéria seca da parte aérea..................... 55

4.2.1.3. Teor de fósforo da parte aérea............................ 57

4.2.1.4. Conteúdo de fósforo da parte aérea........................ 58

4.2.1.5. Atividade de fosfatase ácida no tecido foliar............. 59

4.2.2. Segundo corte .......................................................... 61

4.2.2.1. Número de perfilhos...................................... 61

4.2.2.2. Produção de matéria seca da parte aérea e das raízes... 63

4.2.2.3. Teor de fósforo da parte aérea e das raízes............... 67

4.2.2.4. Conteúdo de fósforo da parte aérea e das raízes.......... 69

4.2.2.5. Atividade de fosfatase ácida em tecido foliar ............ 72

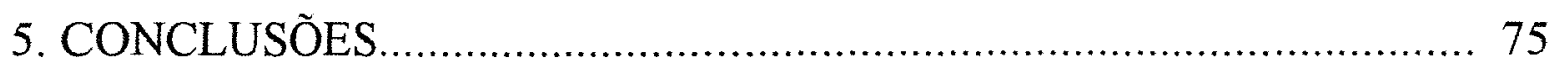

REFERÊNCIAS BIBLIOGRÁFICAS ........................................... 76 


\section{PARÂMETROS PRODUTIVOS E ATIVIDADE DE FOSFATASE ÁCIDA EM TRÊS GRAMÍNEAS FORRAGEIRAS CULTIVADAS COM DOSES DE FÓSFORO.}

\section{Autor: José Eduardo Pereira da Silva Orientador: Prof. Dr. Francisco Antonio Monteiro}

\section{RESUMO}

Foram realizados dois experimentos em câmara-de-crescimento e um em casa-de-vegetação, utilizando solução nutritiva e envolvendo as gramíneas forrageiras Panicum maximum cv. IZ-1, Brachiaria brizantha cv. Marandu e Brachiaria decumbens. O objetivo foi avaliar a atividade de fosfatase ácida em folhas e o desempenho das plantas quanto ao número de perfilhos, produção de matéria seca e teor e conteúdo de fósforo da parte aérea. $\mathrm{O}$ segundo experimento em câmara-de-crescimento objetivou avaliar os desempenhos produtivos durante três períodos de crescimento das plantas. No segundo corte do experimento em casa-de-vegetação foram avaliados também a produção de matéria seca das raízes e o teor e o conteúdo de fósforo das raízes. As doses de fósforo em condições de casade-vegetação, para os dois cortes, foram 3,$1 ; 15,5$ e $31,0 \mathrm{mg} / \mathrm{l}$ e para a 
câmara-de-crescimento de 0,$1 ; 1,0$ e $10,0 \mathrm{mg} / 1$, para o primeiro e o segundo experimento.

O experimento em casa-de-vegetação foi realizado nos meses de novembro e dezembro de 1993, para o primeiro corte e janeiro e fevereiro de 1994, para o segundo corte. Os da câmara-de-crescimento, em condições controladas de umidade, temperatura e luminosidade, foram realizados em fevereiro e março para o primeiro experimento e no segundo em outubro e novembro de 1994. Em cada um dos três experimentos foi utilizado o delineamento de blocos ao acaso, com quatro repetições. Para o primeiro experimento da câmara-de-crescimento a avaliação da atividade de fosfatase foi realizada nas folhas dos capins aos 25 dias após o início do uso da solução nutritiva, enquanto para o segundo foram feitas avaliações aos 14, 21 e 28 dias após o início da aplicação da solução nutritiva. Na casa-devegetação foram executados dois cortes: o primeiro aos 34 dias após o início do uso da solução nutritiva e o segundo 28 dias após o primeiro corte. Os parâmetros avaliados nas plantas foram determinados por ocasião de cada corte, em cada experimento.

Os resultados mostram aumentos significativos $(\mathrm{P}<0,05)$ das doses de fósforo sobre o número de perfilhos, produção de matéria seca da parte aérea e das raízes, e conteúdo de fósforo nas folhas e raízes e redução na atividade de fosfatase ácida das espécies forrageiras. Houve decréscimo na atividade de fosfatase ácida com a elevação das doses de fósforo na solução nutritiva, podendo essa atividade ser utilizada para avaliar o estado 
nutricional dos capins, em relação ao fósforo. Entre as espécies também foram observadas diferenças significativas para os parâmetros analisados. 


\title{
GROWTH PARAMETERS AND ACID PHOSPHATASE ACTIVITY \\ IN THREE FORAGE GRASSES GROWN WITH PHOSPHORUS \\ RATES.
}

\author{
Author: José Eduardo Pereira da Silva \\ Adviser: Prof. Dr. Francisco Antonio Monteiro
}

\section{SUMMARY}

Two experiments with nutrient solutions in a growth chamber and another in a greenhouse were carried out with the forage grasses Panicum maximum cv. IZ-1, Brachiaria brizantha cv. Marandu and Brachiaria decumbens. The objective was to evaluate the acid phosphatase activity and the dry matter yield, tiller number and phosphorus concentration and content in plants. The second experiment in the growth chamber also had the objective of evaluating those forage parameters during three growth periods. Roots dry weight and phosphorus concentrations and content in the roots were determined in the forage at the second harvest in the greenhouse. Phosphorus rates in the greenhouse experiment in the two harvests were 3.1 ; 
15.5 and $31.0 \mathrm{mg} /$ and in the growth chamber were $0.1 ; 1.0$ and $10.0 \mathrm{mg} / \mathrm{l}$, in the first and second experiment.

Greenhouse experiment was done during the months of November and December of 1993 and those in the growth chamber, under controlled condition of humidity, temperature and light incidence, during the months of February and March in the first experiment and in Octomber and November of 1994 in the second experiment. In each experiment it was used a randomized complete block design, with four replications. In the first growth chamber experiment the acid phosphatase activity was determined in plant leaves at 25 days after the beginning of the nutrient solution application, whereas in the second one such activity was determined at 14 , 21 and 28 days after starting the solution use. Two harvests were performed in the greenhouse experiment: the first one at 34 days after the first use of nutrient solution and the second at 28 days after tho first harvest. Several plant parameters were evaluated at each harvest in each experiment.

The results showed significant $(\mathrm{P}<0.05)$ effects of the phosphorus rates on tiller number, forage yield, roots dry weight, and on phosphorus concentration and content in plant top and roots dry weight, the acid phosphatase activity in the forage plants. Acid phosphatase activity decreased as phosphorus rates in the solutions increased, and this activity may be used in order to evaluate the phosphorus nutritional status of these species. Significant differences were observed among the species in terms of the plant parameters evaluated. 


\section{INTRODUÇÃO}

O estabelecimento das pastagens, na maioria dos casos, é feito em áreas onde os solos são originalmente pobres ou foram empobrecidos pela extração de nutrientes pelas plantas de outras culturas.

Os solos brasileiros apresentam níveis extremamente baixos de fósforo disponível. Essa baixa disponibilidade do elemento limita severamente a implantação das pastagens, já que o fósforo é o principal nutriente no estabelecimento da forrageira e apresenta grande influência no aparecimento de perfilhos e no crescimento inicial das raízes.

Com o emprego da adubação fosfatada $o$ aumento da produção forrageira torna-se evidente e também ocorre a melhoria expressiva na qualidade das forrageiras, com reflexos nos animais que utilizam essas pastagens.

Em vista dessa acentuada importância do fósforo nas pastagens, são importantes os estudos que venham a contribuir para melhor conhecimento da relação fósforo-forrageira.

O estudo das fosfatases ácidas, embora realizado com outras plantas, é uma raridade em forrageiras. Ele pode esclarecer importantes aspectos da nutrição dessas plantas quanto ao fósforo, especialmente quando conjugado à abordagem da relação entre níveis de fósforo no substrato e aspectos produtivos e teores do nutriente nas folhas. Também essas enzimas podem servir como critério para a detecção da carência de 
fósforo nessas plantas, mesmo antes do aparecimento de sintomas visuais de deficiência do elemento. 


\section{2 - REVISÃO DE LITERATURA}

\section{1 - Fósforo no solo e na planta}

O fósforo se apresenta, de forma generalizada, em baixo teor disponível nos solos brasileiros, sendo que sua extração pelas plantas é menor, quando comparada com o nitrogênio e potássio, (RAIJ, 1991).

A absorção desse elemento se dá principalmente na forma de $\mathrm{H}_{2} \mathrm{PO}_{4}^{-}$, cuja disponibilidade depende do $\mathrm{pH}$ do meio. $\mathrm{O}$ transporte é realizado na forma de $\mathrm{H}_{2} \mathrm{PO}_{4}^{-}$, através dos feixes vasculares do xilema (MALAVOLTA, 1980). A precipitação do fosfato orgânico nos vasos do xilema pode ocorrer em determinadas condições, como: em presença de altas concentrações de cálcio, cobre, ferro e zinco e também em condições ácidas. A redistribuição do fósforo pelas plantas é rápida e feita através dos vasos do floema. As formas em que o fósforo aparece nas plantas são orgânicas, como ésteres de carboidratos, fosfolipideos, nucleotídeos e ácido fítico (MALAVOLTA, 1980).

São várias as funções que o fósforo desempenha nas plantas. Participa dos processos metabólicos, da transferência de energia, da fase 
inicial das partes reprodutivas, do desenvolvimento radicular e da formação de frutos e sementes (RAIJ, 1991).

\subsection{O fósforo e a nutrição de gramíneas forrageiras}

A exigência pelas plantas quanto ao fósforo difere entre os gêneros, as espécies e os cultivares de forrageiras (SALINAS \& SANCHEZ, 1976).

A baixa disponibilidade de fósforo no solo não permite um bom perfilhamento, proporcionando um espaço livre no pasto para o aparecimento de plantas invasoras menos exigentes em nutrientes. As gramíneas forrageiras sofrendo deficiência de fósforo apresentam lento crescimento, pouco ou nenhum perfilhamento, secamento prematuro das folhas inferiores e pouco desenvolvimento do sistema radicular (WERNER, 1986).

MARTINEZ \& HAAG (1980) estudaram as respostas de sete gramíneas tropicais com doses de fósforo e concluíram que a Brachiaria humidicola (Rendle) Schweickerdt e Hyparrhenia rufa (Ness) Stapf, foram as espécies mais eficientes na absorção e utilização desse nutriente. As outras gramíneas seguiram-se nesta ordem Pennisetum purpureum, Panicum maximum Jacq., Digitaria decumbens Stent, Brachiaria decumbens Stapf e Melinis minutiflora Pal de Beauv. 
MONTEIRO et al. (1995) testaram a Brachiaria brizantha cv. Marandu em solução nutritiva com omissão de cada macronutriente. Aos cinquenta dias após o transplante avaliaram a produção de matéria seca, o número de perfilhos, a altura das plantas e a composição mineral da parte aérea e das raízes. Verificaram que as omissões de nitrogênio e fósforo foram os que mais limitaram o crescimento dessa forrageira, tanto em termos de parte aérea como de raízes. Para o número de perfilhos, o fósforo foi o mais limitante.

MORIKAWA (1993) estudou as limitações nutricionais para a Andropogon gayanus e Brachiaria brizantha em Latossolo da Região dos Campos Vertentes, no Estado de Minas Gerais, e verificou que o fóforo foi o principal nutriente limitante, seguido pelo nitrogênio, potássio e enxofre. $\mathrm{O}$ tratamento com omissão de fósforo limitou a produção de matéria seca da parte aérea, em três cortes, em $98 \%$ em relação ao completo. O perfilhamento das duas espécies foi afetado pela omissão de fósforo.

CORRÊA (1991) estudou doses de fósforo, para o estabelecimento das gramíneas Brachiaria decumbens Stapf, Brachiaria brizantha $\mathrm{cv}$. Marandu e Panicum maximum, em um Latossolo VermelhoAmarelo álico. Os teores críticos de fósforo nas plantas foram da ordem de 0,$11 ; 0,13$ e $0,12 \%$ para decumbens, brizantha e Panicum, respectivamente, no primeiro corte e $0,09,0,12$ e $0,10 \%$, no segundo corte, no experimento em vasos. No experimento de campo a Brachiaria decumbens destacou-se como a menos exigente em fósforo para o estabelecimento, seguindo em ordem crescente o Panicum maximum e Brachiaria brizantha. 
WERNER (1986) citou vários autores que trabalharam com adubação fosfatada, comprovando os beneficios deste nutriente na implantação das braquiárias.

WERNER (1971) trabalhou com doses de fósforo em capimcolonião e verificou significativos incrementos na produção de matéria seca, tanto na parte aérea como das raízes.

MONTEIRO \& WERNER (1977) compararam efeitos do fósforo na formação da pastagem e em pasto estabelecido de capimcolonião, num solo Podzólico Vermelho-Amarelo, com teor muito baixo de fósforo. Verificaram que o fósforo foi indispensável ao estabelecimento da gramínea e que a aplicação de superfosfato simples (500 kg/ha) resultou em aumento de cerca de $20 \%$ na produção de matéria seca do pasto formado.

MEIRELLES et al. (1988) estudaram doses de $\mathrm{P}_{2} \mathrm{O}_{5}$, de $0 ; 25$; $50 ; 75 ; 100 ; 200$ e $400 \mathrm{~kg} / \mathrm{ha}$ em Panicum maximum cv IZ-1 cultivado em dois solos do Estado de São Paulo. Constataram significativos aumentos no número de perfilhos por planta e na produção de matéria seca da parte aérea do capim. As produções máximas desssa gramínea foram obtidas entre as doses 249 e $267 \mathrm{~kg} / \mathrm{ha}$ de $\mathrm{P}_{2} \mathrm{O}_{5}$ para latossolo Vermelho-Escuro e entre 266 e $292 \mathrm{~kg} / \mathrm{ha}$ no Podzólico Vermelho-Amarelo. Observaram que o nível crítico de fósforo nas lâminas das três folhas mais jovens totalmente expandidas, esteve entre 0,16 a $0,19 \%$.

ARAGÃO et al.(1981) trabalharam em dois locais do Estado de Sergipe, (Carira e Aruá) com solos PVE sendo um com média e alta saturação por bases, baixa saturação por alumínio, baixa acidez e baixo teor de fósforo, e o outro com baixa saturação por bases, fortemente ácido e 
baixo teor de fósforo. Observaram que no primeiro local a Brachiaria decumbens respondeu melhor que a Brachiaria humidicola à aplicação do nutriente e o Panicum maximum cv. Gongyloides obteve resposta acentuadamente maior que as braquiárias. Em Aruá a resposta da Brachiaria brizantha foi melhor que as demais braquiárias sem adubação, enquanto a Brachiaria decumbens $\mathrm{cv}$. 910-13 respondeu acentuadamente melhor à aplicação de fósforo $(66,8 \%)$, mostrando uma exigência maior que as demais braquiárias. O número de cortes foi pequeno para uma avaliação, portanto os resultados mostram uma tendência do efeito do fósforo no estabelecimento da pastagem.

\subsection{Atividade de fosfatase ácida}

A Atividade de fosfatase ácida em folhas e raízes tem sido associada com o fósforo nas plantas. O maior grau de deficiência de fósforo normalmente acarreta um aumento na atividade dessas enzimas (BARRETLENNARD, 1982 ; CLARK \& BROWN, 1974; MCLACHLAN, 1976 e MCLACHAN \& DE MARCO, 1982). MCLACHLAN \& DE MARCO (1982) utilizaram a atividade de fosfatase ácida como critério para avaliar o estado nutricional e o grau de deficiência de fósforo nas plantas, antes do aparecimento dos sintomas visuais de deficiência desse nutriente.

EPSTEIN (1975) descreveu que os métodos para diagnosticar o estado nutricional consistem na avaliação de sintomas visuais e nas análises de tecidos foliares e de amostras de solos, podendo a correção ser tardia para poder remediar possíveis perdas na produção vegetal. 
Para a determinação da atividade de fosfatase ácida alguns fatores tem que ser levados em consideração. Esses fatores são: temperatura, pH do meio, substrato, espécies, presença de íons na solução e o tecido analisado.

BIELESKI (1973) descreveu que a função de fosfatase ácida das raízes na nutrição fosfatada das plantas não é bem conhecida. Julgava-se que a maior função delas seria a de hidrolisar o fósforo ligado às substâncias orgânicas não disponível no meio de crescimento, liberando-o para as plantas. Entretanto, resultados de pesquisas com plantas de sorgo em solução nutritiva, evidenciaram que a atividade dessas enzimas pode ser menor com o suprimento de substâncias fosfatadas orgânicas que com as inorgânicas e que a absorção de fósforo pode ser maior nas plantas supridas com fósforo orgânico (FURLANI et al., 1984). Isto pode indicar que outro grupo de fosfatases, que não as ácidas, entrem em ação quando a fonte de fósforo no meio de crescimento seja exclusivamente orgânico.

Outra evidência importante, refere-se ao fato de que genótipos de sorgo, arroz e trigo selecionados como mais eficientes na absorção de fósforo em condições de baixas concentrações do nutriente no meio de crescimento, mostraram mais baixas atividades de fosfatases ácidas nas raízes em relação à genótipos da mesma espécie selecionadas como ineficientes ou menos adaptadas a condições de baixo suprimento do fósforo (FURLANI et al., 1984; MCLACHLAN 1976 ; ZAINI \& MERCADO, 1985).

Em estudo com os genótipos de arroz IAC-3 e IR-45, respectivamente, tolerante e sensível a alumínio no substrato (ZAINI \& 
MERCADO, 1985) evidenciaram que o LAC-3 mostrou-se mais eficiente na absorção do fósforo, apresentando mais baixas atividades de fosfatases em todos os niveis de fósforo, mesmo em presença de alumínio no meio.

BASSO \& SILVA (1992) objetivaram avaliar a atividade das fosfatases ácidas "in vivo"em folha de cana-de-açúcar (Saccharum officinas variedade SP-70-1284), relacionada ao estado nutricional da planta em relação ao fósforo. Concluíram que a atividade de fosfatase ácida pode ser utilizada como parâmetro na avaliação do estado nutricional de fósforo nessa gramínea.

VETORAZZO (1989) estudou o efeito de fatores do solo e de genótipos no crescimento, nutrição e atividade de fosfatase ácida em clones de eucaliptos (Eucalyptus grandis). Avaliou o comportamento de oito classes cultivados em dois locais e em dois solos, usando amostras de folhas para determinar a concentração de nutriente e a atividade de fosfatase ácida. Verificou que a atividade de fosfatase ácida em relação à concentração de fósforo, ao nível de médias de clones, não mostrou significância no período de 54 a 57 meses de idade das plantas. Também constatou tendência à ocorrência de correlação negativa entre a atividade de fosfatase ácida e a cultura das plantas em experimento no solo, Areia Quartzosa.

PALMA et al. (1988) estudaram atividade de fosfatase ácida em um Latossolo Vermelho-Amarelo, textura média, tratada com vinhaça e doses acumuladas sobre a atividade de fosfatase ácida no solo. Concluíram que a adição da vinhaça em doses acumuladas inibiu parcialmente a atividade de fosfatase ácida e aumentou a imobilização dessas enzimas. 
Trabalhos de pesquisa tem sido realizados com solos, já que o fósforo orgânico constitui fração expressiva do fósforo total em muitos solos (APPICH, 1975) e sua mineralização importante para assimilação microbiana e vegetal, realiza-se com participação de fosfatase do solo (APPICH \& THOMAS, 1982) uma vez que essas enzimas catalisam a clivagem hidrolítica da ligação éster-fosfato. A medida das atividades dessas enzimas tem sido utilizada como critério para avaliar a fertilidade do solo (BURANGULOV \& KHAZIEV, 1965). 


\section{MATERIAL E MÉTODOS}

Foram realizados dois experimentos em câmara-de-crescimento e um em casa-de-vegetação na área de Nutrição Mineral de Plantas, do Departamento de Química, da Escola Superior de Agricultura "Luiz de Queiroz", em Piracicaba, Estado de São Paulo.

\subsection{Câmara-de-crescimento}

\subsubsection{Primeiro experimento}

Este experimento foi conduzido no período de 14 de fevereiro a 24 de março de 1994, e buscou avaliar a atividade de fosfatase ácida e desempenhos produtivos nas espécies forrageiras Brachiaria brizantha cv. Marandu, Brachiaria decumbens e Panicum maximum cv. IZ-1.

\subsubsection{Condições de instalação e condução do experimento}

As sementes foram colocadas para germinar em bandejas de alumínio , contendo areia que foi lavada com água corrente e posteriormente com água desionizada. 
O transplante das mudas foi realizado em 26 de fevereiro de1994, colocando-se quinze plântulas por caixa com capacidade de 15 litros. Utilizou-se inicialmente a solução de SARRUGE ( 1975 ), com uma concentração de $10 \%$ da solução completa e a dose de fósforo ajustada para $0,1 \mathrm{mg} / 1$, em todos os tratamentos, durante um periodo de sete dias. A partir de então passou-se a utilizar a solução completa, com três doses de fósforo, na forma de $\mathrm{KH}_{2} \mathrm{PO}_{4}$, mantendo-se constante a dose de potássio, pela adição de $\mathrm{KCl}$, em $\mathrm{pH}=5,0$ (ajustado com $\mathrm{HCl}$ diluído 1/10). Foram necessárias duas adições de Fe - EDTA ( $1,0 \mathrm{mg} / \mathrm{l})$ durante a conduçăo do trabalho, no décimo e vigésimo dias após o transplante, pelo fato de as plantas apresentarem sintomas de deficiência de ferro (clorose internerval em toda a lâmina foliar até a nervura).

Foram executados desbastes periódicos das plantas, até serem deixadas oito plantas de cada espécie por caixa. Na câmara-decrescimento a temperatura variou entre 28 e $34{ }^{\circ} \mathrm{C}$ sendo controlada através de aparelhos de ar condicionado, enquanto a umidade relativa estava ao redor de $60 \%$. As plantas tiveram quatorze horas de luz por dia.

\subsubsection{Tratamentos e delineamento experimental}

As caixas com solução, em número de doze, foram distribuídas segundo o delineamento experimental de blocos ao acaso, com quatro repetições. Os fatores estudados foram três doses de fósforo e três gramíneas forrageiras. Foram testadas as concentrações de fósforo de 0,1 ; 1,$0 ; 10,0 \mathrm{mg} / 1$ ( tabela 1 ) 
Tabela 1. Composição química da solução nutritiva $(\mathrm{ml} / \mathrm{l})$ no primeiro experimento na Câmara-de-crescimento.

\begin{tabular}{|c|c|c|}
\hline Sais utilizados & Concentração & $\begin{array}{c}\text { Volume de solução } \\
\text { estoque por caixa }\end{array}$ \\
\hline $\mathrm{KH}_{2} \mathrm{PO}_{4}$ & $\mathrm{M}$ & $\begin{array}{c}0,1=0,05 \mathrm{ml} / 15 \mathrm{l} \\
1,0=0,50 \mathrm{ml} / 151 \\
10,0=5,00 \mathrm{ml} / 151\end{array}$ \\
\hline $\mathrm{KNO}_{3}$ & $\mathrm{M}$ & $75 \mathrm{ml} / 151$ \\
\hline $\mathrm{Ca}\left(\mathrm{NO}_{3}\right)_{2}$ & $\mathrm{M}$ & $75 \mathrm{ml} / 151$ \\
\hline $\mathrm{Mg} \mathrm{S0}$ & $\mathrm{M}$ & $30 \mathrm{ml} / 151$ \\
\hline $\mathrm{Micro}(-\mathrm{Fe})$ & $-\cdots$ & $15 \mathrm{ml} / 15 \mathrm{l}$ \\
\hline $\mathrm{Fe}-\mathrm{EDTA}$ & ----- & $15 \mathrm{ml} / 151$ \\
\hline $\mathrm{KCl}$ & $\mathrm{M}$ & $\begin{array}{c}0,1=1,97 \mathrm{ml} / 151 \\
1,0=7,41 \mathrm{ml} / 151\end{array}$ \\
\hline
\end{tabular}

A solução de Micronutrientes tinha a seguinte composição ( $\mathrm{g} / \mathrm{l}) \mathrm{H}_{3} \mathrm{BO}_{3}=2,86$, $\mathrm{MnCl}_{2} \cdot 4 \mathrm{H}_{2} \mathrm{O}=1,81, \mathrm{ZnCl}_{2}=0,10, \mathrm{CuCl}_{2}=0,04, \mathrm{H}_{2} \mathrm{MoO} 4=0,02$.

\subsubsection{Coleta do material vegetal}

Aos vinte e cinco dias após o transplante e início do uso da solução nutritiva, foram determinados o número de perfilhos nas plantas e logo após foi coletada a segunda lâmina foliar de cada planta (do topo para a base da planta) para determinação da atividade de fosfatase ácida.

Também foram colhidas as partes aéreas das plantas, as quais foram postas a secar em estufa de circulação forçada de ar a $65^{\circ} \mathrm{C}$, até peso constante. A parte aérea foi pesada para avaliação da produção de matéria seca e logo após foi moída para ser levada ao laboratório, visando a determinação do teor de fósforo no tecido vegetal. $O$ conteúdo de fósforo foi 
obtido pela multiplicação da quantidade de matéria seca pela concentação de fósforo na parte aérea.

\subsubsection{Segundo experimento}

Buscou-se nesse experimento, em câmara-de-crescimento, avaliar o desempenho produtivo e a atividade de fosfatase ácida durante vários períodos do desenvolvimento das plantas.

\subsubsection{Condições de instalação e condução do experimento}

As condições de instalação para a germinação das sementes foram similares às do primeiro experimento em câmara-de-crescimento. A semeadura do Panicum foi efetuada em 04 de outubro de 1994, e das Brachiarias em 09 de outubro de 1994. Assim, o Panicum maximum foi transplantado com 17 dias e as Brachiarias com 12 dias após a semeadura. As soluções nutritivas e a metodologia de condução deste experimento também foram similares às do primeiro experimento.

Também neste experimento foram necessárias novas adições de Fe-EDTA, as quais se deram no décimo e vigésimo dias após transplante, devido aos sintomas de deficiência de ferro (clorose internerval atingindo toda a lâmina foliar até a nervura central). 


\subsubsection{Tratamentos e delineamento experimental}

A distribuição das doze caixas com solução nutritiva foi realizada segundo o delineamento experimental de blocos ao acaso, com quatro repetições. Os fatores testados foram as mesmas três doses de fósforo $(0,1 ; 1,0 ; 10,0 \mathrm{mg} / 1)$ e as mesmas três gramíneas forrageiras.

\subsubsection{Coleta do material vegetal}

Foram determinadas as atividades de fosfatase ácida durante 0 desenvolvimento das plantas, em três épocas, para as três espécies no mesmo período. A primeira avaliação ocorreu aos quatorze dias, a segunda aos vinte e um dias e a terceira e última aos vinte e oito dias após o transplante das mudas para as caixas .

Em cada coleta do material vegetal procedeu-se de forma similar à do primeiro experimento, seguindo-se também a forma para as determinações de número de perfilhos, produção de matéria seca da parte aérea e concentração e conteúdo de fósforo no tecido vegetal.

\subsection{Casa-de-vegetação}

Neste experimento buscou-se avaliar a atividade de fosfatase ácida, e o desempenho produtivo nas espécies de Brachiaria brizantha cv Marandu, Brachiaria decumbens e o Panicum maximum cv IZ-1, crescendo sob doses de fósforo, em casa-de-vegetação. 


\subsubsection{Condições de instalação e condução do experimento}

A germinação das sementes foi realizada em bandejas de alumínio contendo areia lavada inicialmente em água corrente e posteriormente em água desionizada.

O transplante das mudas para os vasos, contendo silica, foi realizado quatorze dias após a semeadura nas bandejas, com o emprego de oito plantas por vaso. Empregou-se um litro de solução de SARRUGE (1975), inicialmente com uma concentração de $10 \%$ da solução completa em todos os vasos, estando o fósforo na dose de $3,1 \mathrm{mg} / 1$. Utilizou-se como fonte de fósforo o $\mathrm{KH}_{2} \mathrm{PO}_{4}$. A troca da solução, para a concentração de cada tratamento ocorreu sete dias após o transplante, e a cada dez dias tratou-se de recompor a solução inicial do tratamento. Entre essas trocas as soluções foram completadas diariamente com água desionizada.

Os desbastes das plantas foram executados até deixar cinco plantas por vaso. As plantas foram cultivadas em dois períodos de crescimento.

\subsubsection{Tratamentos e delineamento experimental}

Os vasos foram distribuídos, em número de trinta e seis, seguindo o delineamento experimental de blocos ao acaso, com quatro repetições. Os fatores estudados foram três doses de fósforo, nas três 
espécies forrageiras. Foram avaliadas as doses de fósforo de 3,$1 ; 15,5 \mathrm{e}$ $31,0 \mathrm{mg} / 1$ ( tabela 2 ).

Tabela 2. Composição química da solução Nutritiva (ml/l) em casa-de- vegetação.

\begin{tabular}{|c|c|c|}
\hline Sais utilizados & Concentração & $\begin{array}{c}\text { Volume de solução estoque } \\
\text { por vaso }\end{array}$ \\
\hline & $\mathrm{M}$ & $\begin{array}{r}3,1=0,01 \mathrm{ml} / 1 \\
15,5=0,50 \mathrm{ml} / 1 \\
31,0=1,00 \mathrm{ml} / 1\end{array}$ \\
\hline $\mathrm{KH}_{2} \mathrm{PO}_{4}$ & $\mathrm{M}$ & $5 \mathrm{ml} / 1$ \\
\hline $\mathrm{KNO}_{3}$ & $\mathrm{M}$ & $5 \mathrm{ml} / 1$ \\
\hline $\mathrm{Ca}\left(\mathrm{NO}_{3}\right)_{2}$ & $\mathrm{M}$ & $1 \mathrm{ml} / 1$ \\
\hline $\mathrm{Mg} \mathrm{SO} 4$ & --- & $1 \mathrm{ml} / 1$ \\
\hline $\mathrm{Micro}(-\mathrm{Fe})$ & --- & $3,1=11,97 / 151$ \\
$\mathrm{Fe}-\mathrm{EDTA}$ & $\mathrm{M}$ & $15,5=7,41 / 151$ \\
\hline $\mathrm{KCl}$ & & \\
\hline
\end{tabular}

A solução de micronutrientes tinha a seguinte composição $(\mathrm{g} / \mathrm{l}) \mathrm{H}_{3} \mathrm{BO}_{3}=2,86$, $\mathrm{MnCl}_{2} .4 \mathrm{H} 2 \mathrm{O}=1,81, \mathrm{ZnCl}_{2}=0,10, \mathrm{CuCl}_{2}=0,04, \mathrm{H}_{2} \mathrm{MoO}_{4}=0,02$.

\subsubsection{Coleta do material vegetal}

Aos trinta e quatro dias após o início do uso das soluções nutritivas nos tratamentos foi determinado o número de perfilhos por vaso e cortada a segunda lâmina foliar a partir do ápice, para a determinação da atividade de fosfatase ácida. Para as determinações de produção de matéria seca utilizou-se a parte aérea das plantas, mais o material coletado para a determinação de fosfatase. Foi determinado o teor de fósforo na parte aérea e 
também foi calculado o conteúdo de fósforo nessa parte das plantas. Aos vinte e oito dias após o primeiro corte foi realizada a contagem do número de perfilhos por vaso e coletada a lâmina foliar para a determinação da atividade de fosfatase ácida. Para a avaliação da produção de matéria seca e as determinações da concentração e conteúdo de fósforo, a planta foi dividida em raizes e parte aérea. As raizes foram lavadas com jatos de água para a retirada da sílica, e em seguida tratou-se de lavar com água desionizada. Todo o material colhido foi posto a secar em estufa com circulação forçada de ar, a $65^{\circ} \mathrm{C}$, até peso constante.

\subsection{Determinações no material vegetal}

\subsubsection{Produção de matéria seca da parte aérea}

Nos experimentos em câmara-de-crescimento foi determinada a produção de matéria seca de toda a parte aérea. No primeiro corte, ao final do período experimental e no segundo a cada determinação da atividade de fosfatase ácida foram colhidas duas plantas para a avaliação de produção de matéria seca.

No experimento em casa-de-vegetação foi determinada a produção de matéria seca da parte aérea no primeiro corte. No segundo corte essa determinação foi realizada na parte aérea e nas raízes. 


\subsubsection{Determinação do teor de fósforo no tecido vegetal}

Após a pesagem do material vegetal colhido e secado, as plantas foram moídas para se determinar a concentração de fósforo, com o emprego da digestão nítrico-perclórica, conforme a metodologia descrita por SARRUGE \& HAAG (1974).

\subsubsection{Atividade de fosfatase ácida no tecido foliar}

Para a avaliação da atividade de fosfatase ácida foram utilizados $100 \mathrm{mg}$ de fragmentos de $3 \mathrm{~mm}$ de lâminas foliares. Estas ficaram incubadas com $8,0 \mathrm{ml}$ de p-nitrofenilfosfato $250 \mu \mathrm{M}$ em tampão de acetato de sódio ( $\mathrm{CH}_{3}-\mathrm{COONa}$ ) 0,1 $\mathrm{M}$ em $\mathrm{pH}=4,0$. Os fragmentos de tecido vegetal ficaram incubados por 20 minutos a $30^{\circ} \mathrm{C}$. Foram pipetados $5,0 \mathrm{ml}$ da reação, com $2,0 \mathrm{ml}$ de $\mathrm{NaOH} 2 \mathrm{~N}$.

Foram coletadas duas amostras por planta e determinada a atividade de fosfatase ácida com leituras realizadas com uma diferença de 20 minutos entre uma amostra e outra.

As leituras foram realizadas espectrofotometricamente, em comprimento de onda de $420 \mathrm{~nm}$ comparando-se os teores de p-nitrofenol formado na hidrólise e expressando-se a atividade de fosfatase em $\mu \mathrm{M}$ de substrato hidrolisado por hora por grama de matéria de tecido vegetal fresco. 


\subsubsection{Conteúdo de fósforo da parte aérea}

Para a determinação do conteúdo de fósforo foi utilizado o teor de fósforo multiplicado pela quantidade de matéria seca e por dez para se expressar os resultados em $\mathrm{mg} / \mathrm{vaso}$.

\subsubsection{Número de perfilhos}

Foi contado o número de perfilhos por caixa ou por vaso, conforme o caso, por ocasião de cada colheita em cada experimento. 


\section{RESULTADOS E DISCUSSÃO}

\subsection{Câmara-de-crescimento}

\subsubsection{Primeiro experimento}

\subsubsection{Número de perfilhos}

O número de perfilhos nas cinco plantas foi significativamente $(\mathrm{P}<0,05$ ) influenciado pela interação entre espécies e doses de fósforo. $\mathrm{O}$ desdobramento dessa interação é apresentado na tabela 3.

Tabela 3. Número de perfilhos, em cinco plantas, dos três capins submetidos a doses de fósforo.

\begin{tabular}{|c|c|c|c|}
\hline \multirow{2}{*}{$\begin{array}{c}\text { Fósforo } \\
\mathrm{mg} / \mathrm{l}\end{array}$} & \multicolumn{3}{|c|}{ Capins } \\
\cline { 2 - 4 } & $\mathrm{IZ}-1$ & brizantha & decumbens \\
\hline 0,1 & $6,75 \mathrm{bA}$ & $8,25 \mathrm{bA}$ & $7,00 \mathrm{bA}$ \\
\hline 1,0 & $10,50 \mathrm{bA}$ & $11,00 \mathrm{bA}$ & $9,50 \mathrm{bA}$ \\
\hline 10,0 & $22,75 \mathrm{aA}$ & $20,00 \mathrm{aAB}$ & $16,50 \mathrm{aB}$ \\
\hline
\end{tabular}

C.V. $=12,9 \%$

DMS - Tukey a $5 \%$ para média das espécies e das doses $=1,64$

Letras maiúsculas diferentes em cada linha e letras minúsculas diferentes em cada coluna indicam diferença significativa ao nivel de $5 \%$ de probabilidade. 
O número de perfilhos foi semelhante nas três espécies, exceto para a dose mais elevada de fósforo $(10,0 \mathrm{mg} / \mathrm{l})$, na qual a Brachiaria decumbens diferiu do Panicum maximum IZ - 1.

O número de perfilhos variou significativamente com as doses de fósforo e pode ser observado que o maior número ocorreu com a dose $10,0 \mathrm{mg} / \mathrm{l}$, nas três espécies. A dose mais baixa de fósforo $(0,1 \mathrm{mg} / \mathrm{l})$ apresentou plantas, em sua maioria, sem perfilhos laterais (apenas a haste da planta mãe prevaleceu na contagem dos perfilhos), como mostra a figura 1.

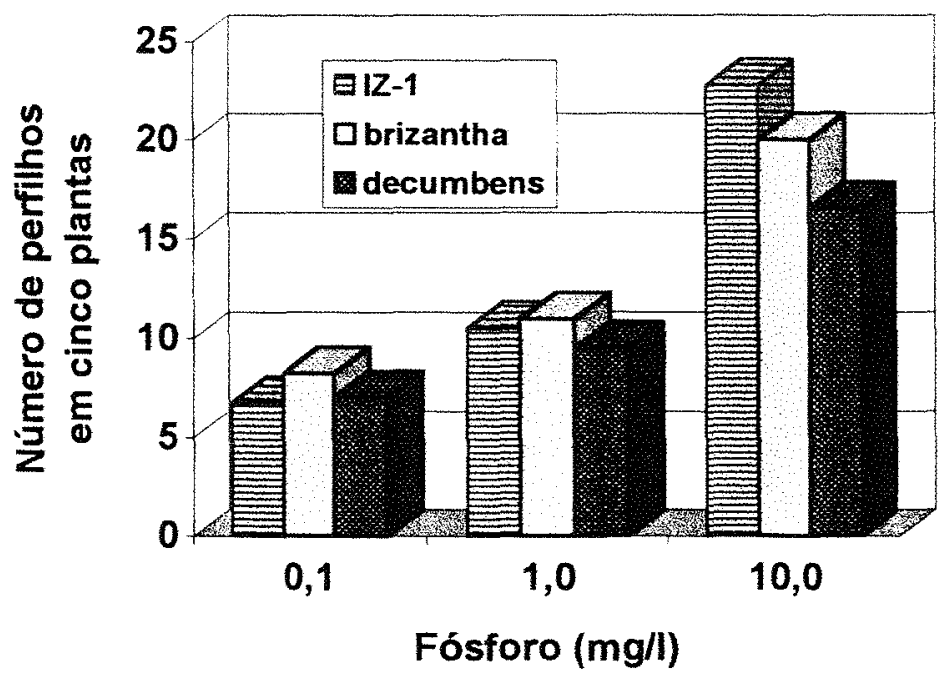

Figura 1. Número de perfilhos, em cinco plantas, submetidos a doses de fósforo, em três espécies de forrageiras estudadas.

Resultados semelhantes foram encontrados por WERNER et al. (1967) com Panicum maximum, SERRÃO \& SIMÃO NETO (1971) com Brachiaria decumbens e MONTEIRO et al. (1995) com Brachiaria brizantha cv Marandu. 
Estes resultados ilustram a importância que o fósforo desempenha no perfilhamento inicial das gramíneas forrageiras, como descrito por WERNER (1986).

\subsubsection{Produção de matéria seca da parte aérea}

A produção de matéria seca também mostrou significância para a interação entre as espécies e as doses de fósforo estudadas, como mostra a tabela 4.

A produção de matéria seca apresentou valores semelhantes nas três espécies estudadas, diferindo apenas na dose mais elevada de fósforo $(10,0 \mathrm{mg} / 1)$, onde o Panicum maximum $\mathrm{IZ}-1$ mostrou valor mais alto que a Brachiaria decumbens.

Ocorreu um aumento de rendimento da matéria seca da parte aérea pelas espécies, em função das doses de fósforo, como mostra a figura 2.

Tabela 4. Produção de matéria seca da parte aérea (g/caixa) nas três espécies forrageiras, submetidas a doses de fósforo, em três capins.

\begin{tabular}{|c|c|c|c|}
\hline \multirow{2}{*}{$\begin{array}{c}\text { Fósforo } \\
\mathrm{mg} / \mathrm{l}\end{array}$} & \multicolumn{3}{|c|}{ Capins } \\
\cline { 2 - 4 } & $\mathrm{IZ}-1$ & brizantha & decumbens \\
\hline 0,1 & $1,94 \mathrm{bA}$ & $2,25 \mathrm{bA}$ & $1,76 \mathrm{cA}$ \\
\hline 1,0 & $3,32 \mathrm{bA}$ & $2,89 \mathrm{bA}$ & $2,18 \mathrm{bA}$ \\
\hline 10,0 & $6,62 \mathrm{aA}$ & $4,26 \mathrm{aAB}$ & $4,01 \mathrm{aB}$ \\
\hline
\end{tabular}

C.V. $=22,9 \%$

DMS - Tukey a $5 \%$ para média das espécies e das doses $=0,75$

Letras maiúsculas diferentes em cada linha e letras minúsculas diferentes em cada coluna indicam diferença significativa ao nível de $5 \%$ de cada probabilidade. 


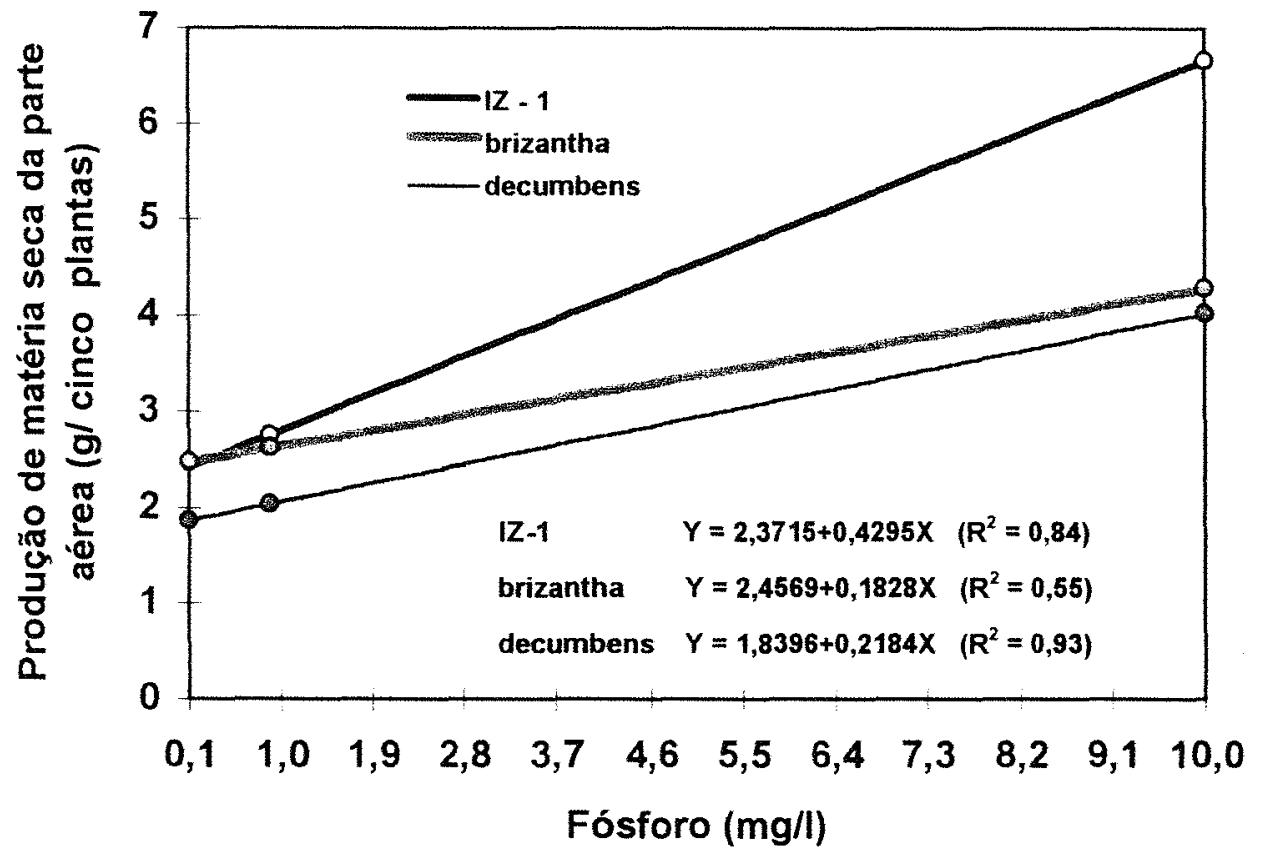

Figura 2. Produção de matéria seca da parte aérea ( $g /$ cinco plantas) nas três espécies forrageiras submetidas a doses de fósforo, na câmarade-crescimento.

As equações demonstram um ajuste para o modelo linear da produção de matéria seca em função das doses de fósforo, para cada uma das três forrageiras. Os valores dessa produção foram mais elevados no Panicum maximum IZ-1. As espécies apresentam um potencial para responder a doses mais elevadas de fósforo que os empregados no presente estudo. MONTEIRO et al. (1995), trabalhando com Brachiaria brizantha cv Marandu, em omissão de fósforo obtiveram baixo valor de produção de matéria seca. É sabido que o fósforo, desempenha importante papel no crescimento inicial e formação da planta, devido à baixa reserva em fósforo que as sementes dessas forrageiras possuem, em vista de seu tamanho diminuto (WERNER \& MATTOS, 1972). 


\subsubsection{Teor de fósforo no tecido vegetal}

O teor de fósforo nas plantas apresentou variação significativa $(\mathrm{P}<0,05)$ para as doses de fósforo estudadas. $\mathrm{O}$ aumento no teor de fósforo nas plantas (médias das espécies) foi linear conforme a elevação nas doses de fósforo na solução nutritiva, como mostra a figura 3 .

Os teores de fósforo observados na parte aérea situaram-se acima do observado por ARROYO-AGUILU \& COWARD-LORD (1974) e estiveram acima do nível crítico apontado por CORRÊA (1991). O teor médio de fósforo na parte aérea diferiu significativamente $(\mathrm{P}<0,05)$ entre as espécies de Panicum maximum IZ-1 (0,23\%) e Brachiaria decumbens $(0,19 \%)$ ficando a Brachiaria brizantha $(0,22 \%)$ como intermediária.

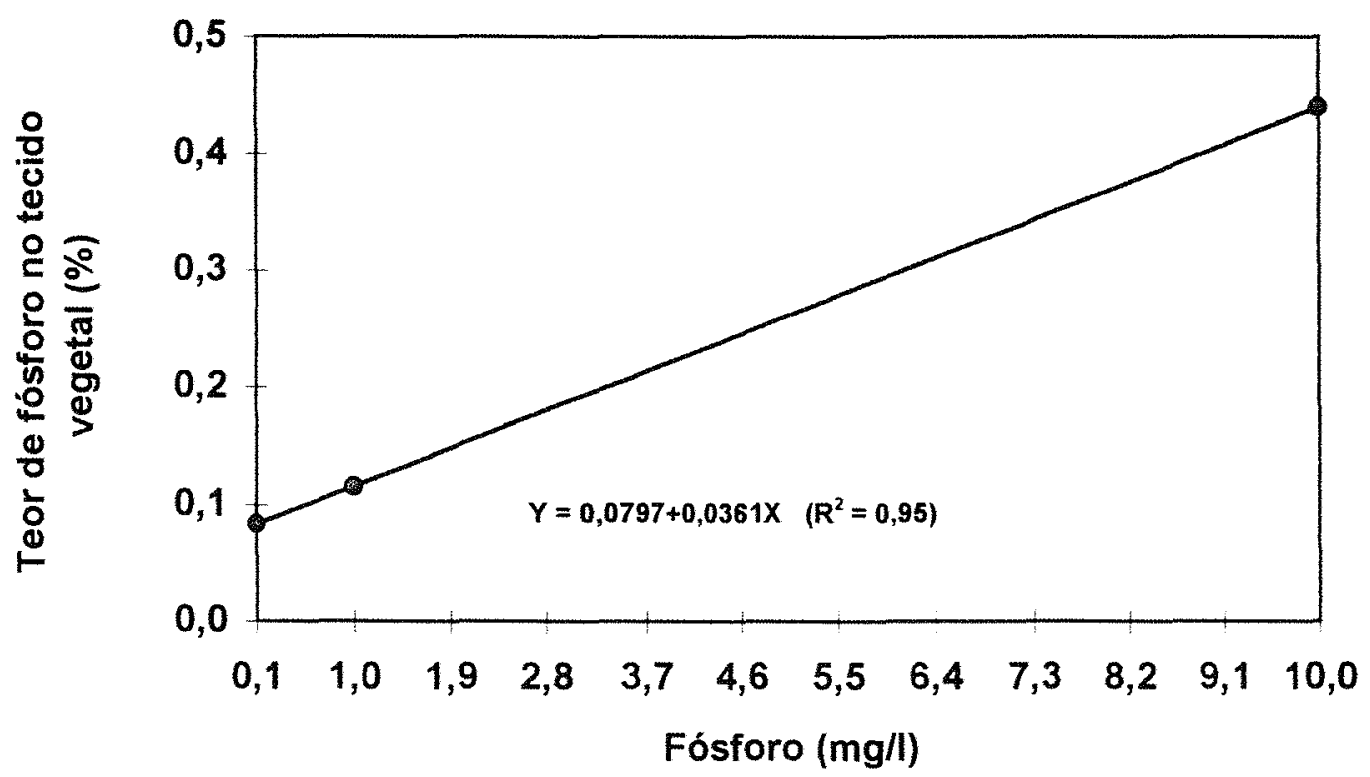

Figura 3. Teor de fósforo (\%), no tecido vegetal, de três capins submetidos a doses de fósforo, na câmara-de-crescimento. 


\subsubsection{Conteúdo de fósforo da parte aérea}

Houve significância $(\mathrm{P}<0,05)$ para a interação entre espécies e doses de fósforo para o conteúdo de fósforo nas plantas. O desdobramento dessa interação é mostrado na tabela 5 .

A espécie de Panicum maximum apresentou mais alto conteúdo de fósforo na parte aérea que a Brachiaria brizantha e esta que a Brachiaria decumbens, na dose de fósforo de $10,0 \mathrm{mg} / 1$. Para as outras doses de fósforo os valores foram semelhantes e isto se deve ao aumento de produção de matéria seca da parte aérea do IZ-1 para a dose mais elevada de fósforo e uma concentração maior de IZ-1 em relação às braquiárias.

Tabela 5. Conteúdo de fósforo (mg/cinco plantas) nos três capins submetidos a doses de fósforo, em câmara-de-crescimento.

\begin{tabular}{|c|r|r|r|}
\hline \multirow{2}{*}{$\begin{array}{c}\text { Fósforo } \\
\mathrm{mg} /\end{array}$} & \multicolumn{3}{|c|}{ Capins } \\
\cline { 2 - 4 } & IZ-1 & brizantha & decumbens \\
\hline 0,1 & $1,28 \mathrm{bA}$ & $1,13 \mathrm{bA}$ & $1,10 \mathrm{bA}$ \\
\hline 1,0 & $3,02 \mathrm{bA}$ & $3,05 \mathrm{bA}$ & $2,27 \mathrm{bA}$ \\
\hline 10,0 & $23,09 \mathrm{aA}$ & $20,20 \mathrm{aB}$ & $13,33 \mathrm{aC}$ \\
\hline
\end{tabular}

C.V. $=18,5 \%$

DMS - Tukey a $5 \%$ para média das espécies e das doses $=1,43$

Letras maiúsculas diferentes em cada linha e letras minúsculas diferentes em cada coluna indicam diferença significativa ao nível de $5 \%$ de probabilidade.

O conteúdo de fósforo nas forrageiras aumentou com a elevação das doses de fósforo, como mostra a figura 4. 


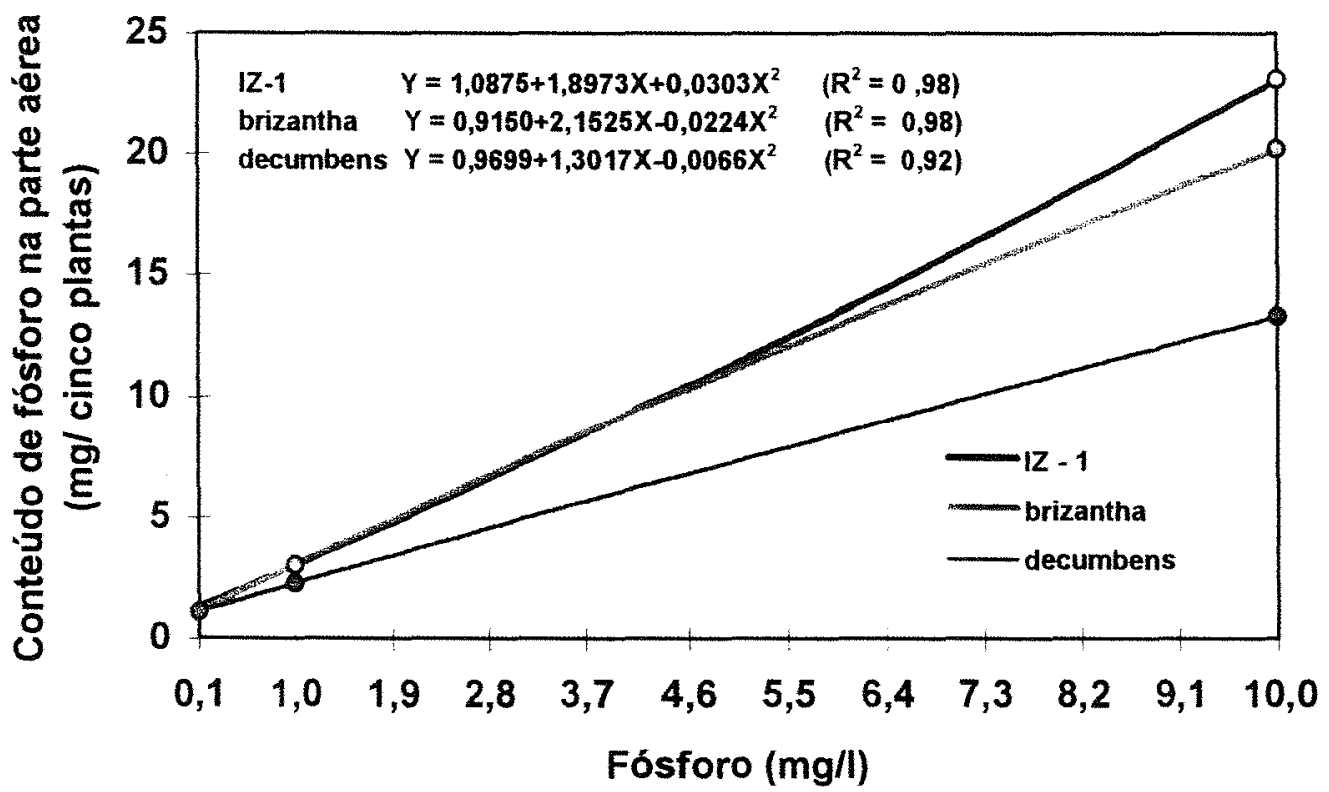

figura 4. Conteúdo de fósforo ( $\mathrm{mg} /$ cinco plantas) na parte aérea de três espécies forrageiras sob três doses de fósforo, em câmara-de-crescimento.

Com o aumento nas doses de fósforo na solução, houve uma elevação no conteúdo de fósforo como mostra a figura 4.

\subsubsection{Atividade de fosfatase ácida no tecido foliar}

A atividade de fosfatase ácida não variou significativamente $(\mathrm{P}>0,05)$ entre as espécies, as quais tiveram as seguintes médias de atividades: $\mathrm{IZ}-1=258,37$, brizantha $=235,29$ e decumbens $=240,44 \mu \mathrm{M}$ $\mathrm{pNPP} / \mathrm{h} / \mathrm{g}$ de tecido foliar fresco. 
A atividade de fosfatase ácida diferiu significativamente $(\mathrm{P}<0,05)$ para as doses de fósforo. Conforme as doses desse nutriente aumentaram na solução nutritiva, a atividade de fosfatase ácida resultou em decréscimo, o qual foi linear (figura 5). Estes resultados podem auxiliar na avaliação do grau de deficiência de fósforo das plantas, de acordo com MCLACHLAN \& DE MARCO (1982).

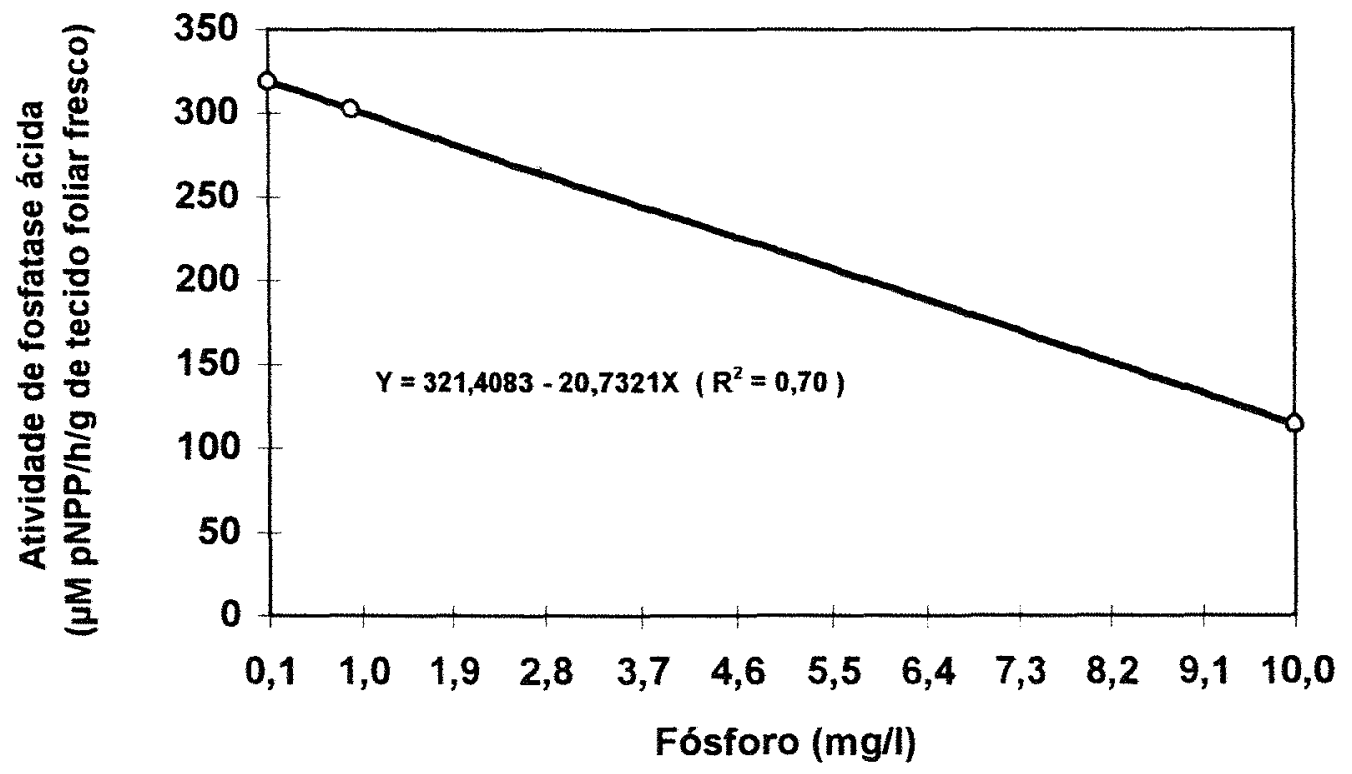

Figura 5. Atividade de fosfatase ácida $(\mu \mathrm{M} \mathrm{pNPP/h} / \mathrm{g}$ de tecido foliar fresco) em folhas de três forrageiras, submetidas a três doses de fósforo, em câmara-de-crescimento.

Quando considerada a correlação da produção de matéria seca da parte aérea com a atividade de fosfatase ácida, pode-se notar que a espécie IZ-1 mostrou o maior coeficiente de correlação $(r=-0,85)$ entre as espécies e foi seguido pela brizantha $(r=-0,78)$ e decumbens $(r=-0,72)$. 
As correlaçōes apresentaram coeficientes elevados quando se relacionou a concentração de fósforo com a atividade de fosfatase ácida, principalmente para a Brachiaria brizantha $(\mathrm{r}=-0,96)$. Em todas as espécies estudadas essa relação teve coeficiente negativo, caracterizando que há uma relação inversa entre atividade de fosfatase ácida e a concentração de fósforo no tecido dessas plantas.

\subsubsection{Segundo experimento}

Este experimento foi realizado com três épocas de colheita, ou seja, 14, 21 e 28 dias após o transplante.

\subsubsection{Número de perfilhos}

O número de perfilhos anotado à época de colheita das plantas variou significativamente $(\mathrm{P}<0,05)$ com doses de fósforo, por ocasião do $14^{\circ}$ dia após o transplante. Entre as espécies não ocorreu significância $(P>0,05)$ na variação do número de perfilhos, nessa colheita. O número de perfilhos alcançado com mais alta dose de fósforo na solução nutritiva $(10,0 \mathrm{mg} / 1)$ foi $57 \%$ mais elevada que o obtida na mais baixa dose de fósforo $(0,1 \mathrm{mg} /)$.

Nas outras duas colheitas (21 e 28 dias após o transplante) ocorreram significâncias $(\mathrm{P}<0,05)$ para a interação entre as doses de fósforo e as espécies, sendo isso ilustrado nas tabelas 6 e 7 . 
Tabela 6. Número de perfilhos em duas plantas de cada um dos três capins submetidos a doses de fósforo, por ocasião do $21^{0}$ dia após 0 transplante.

\begin{tabular}{|c|c|c|c|}
\hline \multirow{2}{*}{$\begin{array}{c}\text { Fósforo } \\
\mathrm{mg} / 1\end{array}$} & \multicolumn{3}{|c|}{ Capins } \\
\cline { 2 - 4 } & $\mathrm{IZ}-1$ & brizantha & decumbens \\
\hline 0,1 & $2,50 \mathrm{cA}$ & $3,25 \mathrm{bA}$ & $2,50 \mathrm{cA}$ \\
\hline 1,0 & $5,75 \mathrm{bA}$ & $6,25 \mathrm{aAB}$ & $3,75 \mathrm{bB}$ \\
\hline 10,0 & $9,00 \mathrm{aA}$ & $7,75 \mathrm{aA}$ & $6,25 \mathrm{aB}$ \\
\hline
\end{tabular}

C.V. $=14,0 \%$

DMS - Tukey a $5 \%$ para média das espécies e das doses $=0,75$

Letras maiúsculas diferentes em cada linha e letras minúsculas diferentes em cada coluna, indicam diferença significativa ao nivel de $5 \%$ de probabilidade.

Tabela 7. Número de perfilhos em duas plantas de cada um dos três capins submetidos a doses de fósforo, por ocasião do $28^{\circ}$ dia após o transplante.

\begin{tabular}{|c|c|c|c|}
\hline \multirow{2}{*}{$\begin{array}{c}\text { Fósforo } \\
\mathrm{mg} / 1\end{array}$} & \multicolumn{3}{|c|}{ Capins } \\
\cline { 2 - 4 } & IZ-1 & brizantha & decumbens \\
\hline 0,1 & $2,75 \mathrm{cA}$ & $3,50 \mathrm{cA}$ & $2,25 \mathrm{cA}$ \\
\hline 1,0 & $6,25 \mathrm{bA}$ & $6,75 \mathrm{bA}$ & $4,25 \mathrm{bB}$ \\
\hline 10,0 & $9,50 \mathrm{aA}$ & $8,25 \mathrm{aA}$ & $6,50 \mathrm{aB}$ \\
\hline
\end{tabular}

C.V. $=11,1 \%$

DMS - Tukey a 5\% para média das espécies e das doses $=0,66$

Letras msiúsculas diferentes em cada linha e letras minúsculas diferentes em cada coluna, indicam diferença significativa ao nível de $5 \%$ de probabilidade. 
Entre as espécies somente não foi significativa a variação no número de perfilhos na dose mais baixa de fósforo $(0,1 \mathrm{mg} / \mathrm{l})$, por ocasião do $21^{\circ}$ e $28^{\circ}$ dias após o transplante. Com o emprego das doses mais elevadas de fósforo, a Brachiaria decumbens mostrou perfilhamento significativamente inferior ao das outras duas espécies estudadas.

As espécies, nos dois períodos, apresentaram aumento significativo no número de perfilhos, em função da elevação das doses de fósforo, respondendo à adubação com fósforo e mostrando a importância que desempenha esse nutriente no perfilhamento inicial das gramíneas forrageiras (WERNER, 1986).

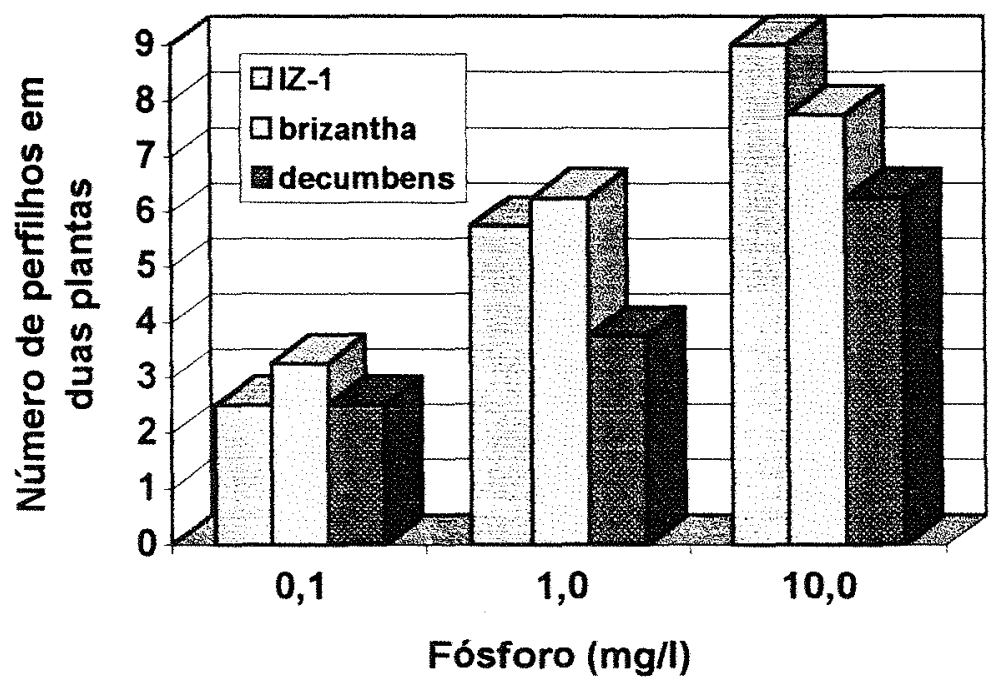

Figura 6. Número de perfilhos no $21^{\varrho}$ dia após o transplante, em duas plantas, com três espécies de forrageiras submetidas a doses de fósforo. 


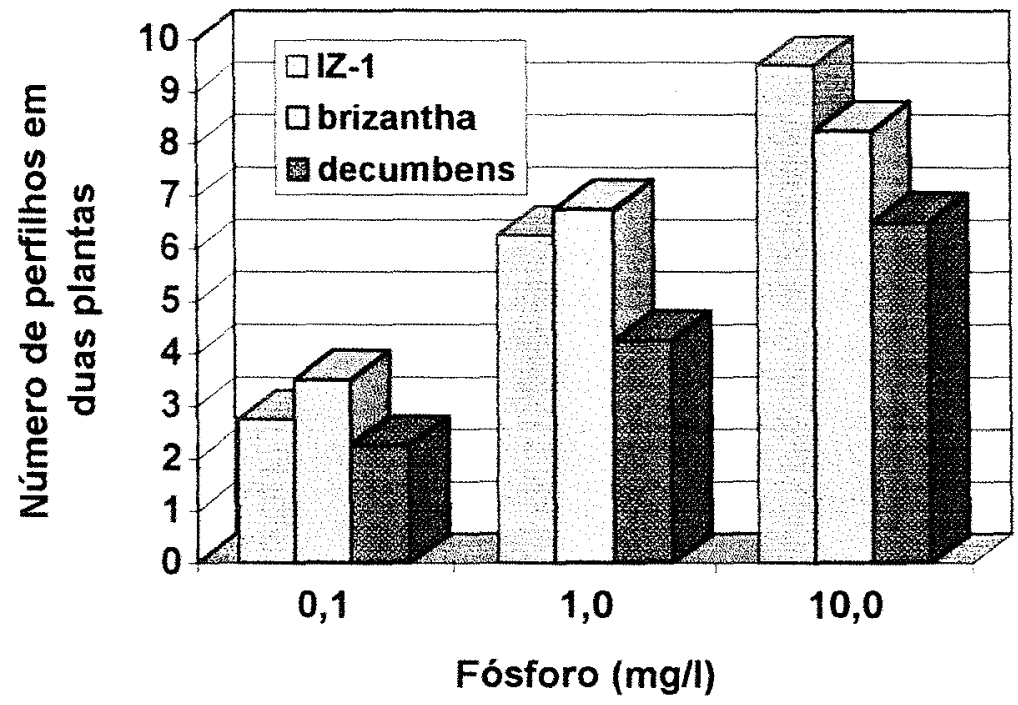

Figura 7. Número de perfilhos no $28^{\circ}$ dia após o transplante, em duas plantas, com três espécies de forrageiras submetidos a doses de fósforo.

\subsubsection{Produção de matéria seca da parte aérea}

A produção de matéria seca pelas plantas, aos 14 dias após o transplante, mostrou efeitos significativos $(\mathrm{P}<0,05)$ para as espécies e as doses de fósforo. O Panicum maximum apresentou uma produção de matéria seca mais elevada que a Brachiaria brizantha e a Brachiaria decumbens, de forma similar ao observado no primeiro experimento, embora neste caso tenha sido bem mais curto o período de crescimento.

A produção de matéria seca das forrageiras foi linear e positivamente incrementada com o aumento das doses de fósforo. A produção alcançada com a maior dose de fósforo na solução nutritiva $(10,0 \mathrm{mg} / \mathrm{l})$ foi 
$33 \%$ mais elevada que aquela obtida na mais baixa dose de fósforo $(0,1 \mathrm{mg} /)$. Nas outras duas épocas de colheita ( 21 e 28 dias após o transplante), verificou-se interação significativa entre as doses de fósforo e as espécies, para a produção de matéria seca. $\mathrm{Na}$ comparação entre as espécies somente se constatou variação significativa na dose $10,0 \mathrm{mg} / \mathrm{l}$, onde $\mathrm{o}$ IZ - 1 foi superior aos outros dois capins, no $21^{\underline{0}}$ dia após o transplante (tabela 8). No $28^{\circ}$ dia só não houve diferença significativa entre as espécies, para a dose $10,0 \mathrm{mg} / 1$. Na dose mais baixa de fósforo $(0,1 \mathrm{mg} / \mathrm{l})$ o capim IZ-1 apresentou a maior produção, seguido pela decumbens e pela brizantha. Para a dose $1,0 \mathrm{mg} / \mathrm{l}$ as braquiárias não apresentaram diferença significativa entre si, mas o fizeram em relação ao Panicum maximum (tabela 9).

Tabela 8. Produção de matéria seca ( $\mathrm{g} / \mathrm{caixa}$ ) da parte aérea dos três capins submetidas a doses de fósforo, no $21^{\circ}$ dia do transplante.

\begin{tabular}{|c|c|c|c|}
\hline \multirow{2}{*}{$\begin{array}{c}\text { Fósforo } \\
\mathrm{mg} / 1\end{array}$} & \multicolumn{3}{|c|}{ Capins } \\
\cline { 2 - 4 } & $\mathrm{IZ}-1$ & brizantha & decumbens \\
\hline 0,1 & $0,29 \mathrm{bA}$ & $0,27 \mathrm{bA}$ & $0,18 \mathrm{cA}$ \\
\hline 1,0 & $0,40 \mathrm{bA}$ & $0,35 \mathrm{abA}$ & $0,29 \mathrm{bA}$ \\
\hline 10,0 & $0,75 \mathrm{aA}$ & $0,43 \mathrm{aB}$ & $0,39 \mathrm{aB}$ \\
\hline
\end{tabular}

C.V. $=17,5 \%$

DMS - Tukey a $5 \%$ para média das espécies e das doses $=0,07$

Letras maiúsculas diferentes em cada linha e letras minúsculas diferentes em cada coluna indicam diferença significativa ao nivel de $5 \%$ de probabilidade. 
Tabela 9. Produção de matéria seca (g/caixa) da parte aérea dos três capins submetidos a doses de fósforo, no $28^{\circ}$ dia do transplante.

\begin{tabular}{|c|c|c|c|}
\hline \multirow{2}{*}{$\begin{array}{c}\text { Fósforo } \\
\mathrm{mg} / 1\end{array}$} & \multicolumn{3}{|c|}{ Capins } \\
\cline { 2 - 4 } & IZ-1 & brizantha & decumbens \\
\hline 0,1 & $0,71 \mathrm{cA}$ & $0,51 \mathrm{cC}$ & $0,59 \mathrm{cB}$ \\
\hline 1,0 & $1,29 \mathrm{bA}$ & $0,78 \mathrm{bB}$ & $0,90 \mathrm{bB}$ \\
\hline 10,0 & $1,60 \mathrm{aA}$ & $1,45 \mathrm{aA}$ & $1,59 \mathrm{aA}$ \\
\hline
\end{tabular}

C.V. $=7,7 \%$

DMS - Tukey a $5 \%$ para média das espécies e das doses $=0,08$

Letras maiúsculas diferentes em cada linha e letras minúsculas diferentes em cada coluna indicam diferença significativa ao nível de $5 \%$ de probabilidade.

No corte realizado aos 21 dias após o transplante as gramíneas responderam as doses de fósforo, aumentando suas produções de matéria seca da parte aérea (figura 8).

As equações demonstram efeito quadrático na produção de matéria seca, em função das doses de fósforo, para cada uma das forrageiras estudadas. O IZ-1 apresentou um ponto de máximo na dose de $7,8 \mathrm{mg} / \mathrm{l}$, diferenciando das braquiárias que tiveram esse ponto em $5,5 \mathrm{mg} / \mathrm{l}$. 
Para este período ( $28^{\circ}$ dia após o transplante) as espécies também apresentaram respostas às doses de fósforo na solução, com pontos de máximos de: $I Z-1=5,5 \mathrm{mg} / 1$ e as braquiárias $=7,8 \mathrm{mg} / 1$. Para o $21^{\circ}$ dia, 0 IZ-1 apresentou ponto de máximo com dose mais alta que as braquiárias, ocorrendo o inverso no $28^{\circ}$ dia após o transplante.

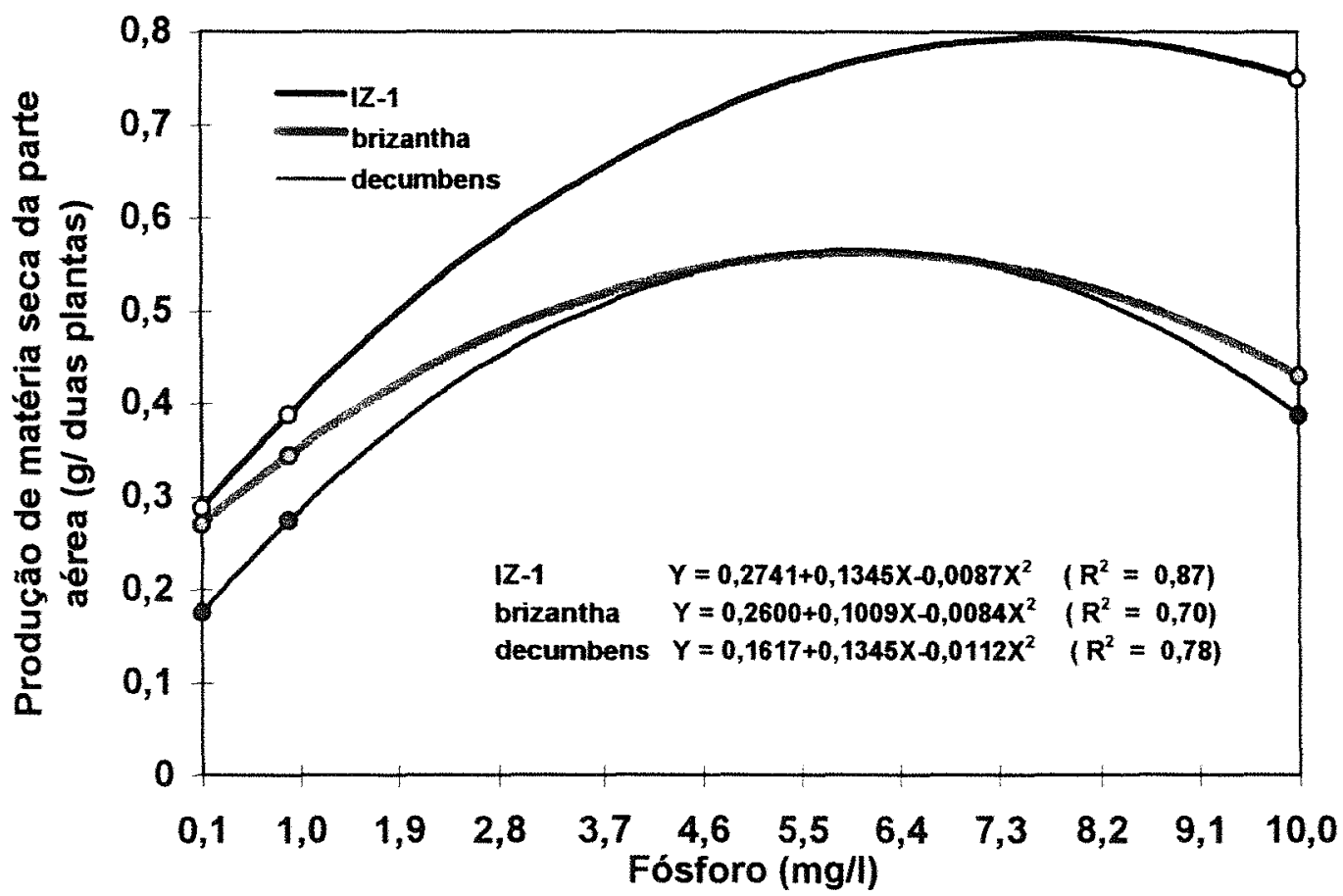

Figura 8. Produção de matéria seca da parte aérea no $21^{0}$ dia após o transplante, em duas plantas de três espécies forrageiras submetidas a doses de fósforo. 


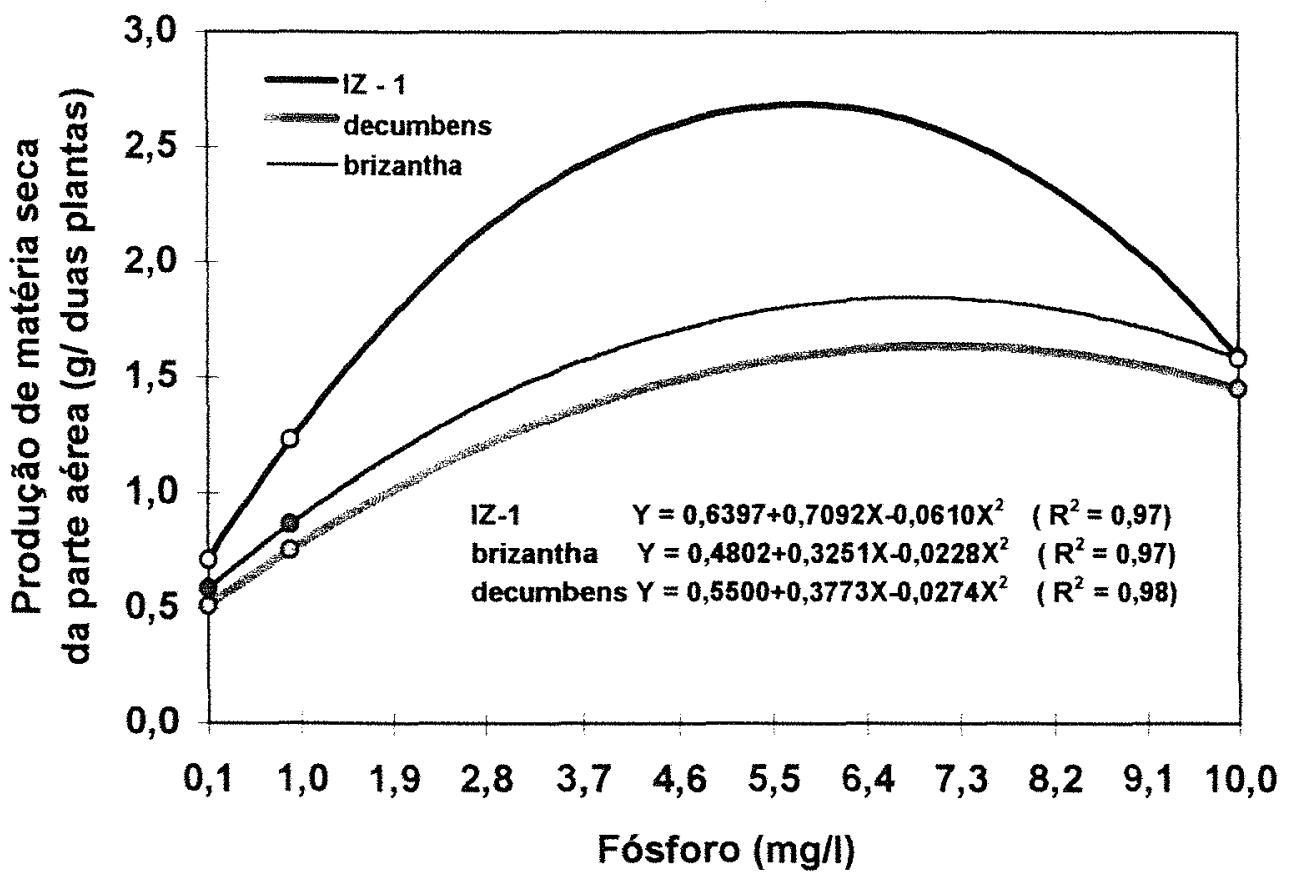

Figura 9. Produção de matéria seca da parte aérea no $28^{0}$ dia após o transplante, em duas plantas em três espécies forrageiras submetidas a doses de fósforo.

\subsubsection{Teor de fósforo da parte aérea}

A variação do teor de fósforo no tecido vegetal teve efeito significativo da interação entre espécies e doses de fósforo. O desdobramento dessas interações é mostrado nas tabelas 10,11 e 12 . 
Tabela 10. Teor de fósforo (\%), em duas plantas, na parte aérea dos três capins submetidas a doses de fósforo, por ocasião do $14^{0}$ dia após o transplante.

\begin{tabular}{|c|c|c|c|}
\hline \multirow{2}{*}{$\begin{array}{c}\text { Fósforo } \\
\mathrm{mg} / 1\end{array}$} & \multicolumn{3}{|c|}{ Capins } \\
\cline { 2 - 4 } & $\mathrm{IZ}-1$ & brizantha & decumbens \\
\hline 0,1 & $0,19 \mathrm{cA}$ & $0,22 \mathrm{cA}$ & $0,11 \mathrm{cB}$ \\
\hline 1,0 & $0,42 \mathrm{bAB}$ & $0,50 \mathrm{bA}$ & $0,35 \mathrm{bB}$ \\
\hline 10,0 & $0,77 \mathrm{aA}$ & $0,76 \mathrm{aA}$ & $0,50 \mathrm{aB}$ \\
\hline
\end{tabular}

C.V. $=13,7 \%$

DMS - Tukey a $5 \%$ para média das espécies e das doses $=0,06$

Letras maiúsculas diferentes em cada linha e letras minúsculas diferentes em cada coluna, indicam diferença significativa ao nível de $5 \%$ de probabilidade.

Ocorreram diferenças significativas $(\mathrm{P}<0,05)$ entre as espécies, por ocasião do $14^{\circ}$ dia após o transplante. A Brachiaria decumbens apresentou valor mais baixo que a Brachiaria brizantha, em qualquer das doses de fósforo na solução e que o Panicum maximum nas doses 0,1 e 10,0 $\mathrm{mg} / 1$.

Para as três doses de fósforo estudadas a Brachiaria decumbens apresentou o menor valor em comparação com as outras espécies. O Panicum maximum e a Brachiaria brizantha não diferiram entre si, para as três doses. 
Tabela 11. Teor de fósforo (\%), em duas plantas, na parte aérea dos três capins submetidas a doses de fósforo, por ocasião do $21^{\circ}$ dia do transplante.

\begin{tabular}{|c|c|c|c|}
\hline \multirow{2}{*}{$\begin{array}{c}\text { Fósforo } \\
\mathrm{mg} / 1\end{array}$} & \multicolumn{3}{|c|}{ Capins } \\
\cline { 2 - 4 } & $\mathrm{IZ}-1$ & brizantha & decumbens \\
\hline 0,1 & $0,09 \mathrm{bA}$ & $0,11 \mathrm{bA}$ & $0,10 \mathrm{bA}$ \\
\hline 1,0 & $0,15 \mathrm{bB}$ & $0,28 \mathrm{bA}$ & $0,19 \mathrm{bB}$ \\
\hline 10,0 & $0,80 \mathrm{cA}$ & $0,73 \mathrm{aA}$ & $0,45 \mathrm{aA}$ \\
\hline
\end{tabular}

C.V. $=34,6 \%$

DMS - Tukey a $5 \%$ para média das espécies e das doses $=0,11$

Letras maiúsculas diferentes em cada linha e letras minúsculas diferentes em cada coluna, indicam diferença significativa ao nível de $5 \%$ de probabilidade.

Tabela 12. Teor de fósforo (\%) da parte aérea dos três capins submetidas a doses de fósforo, por ocasião do $28^{\circ}$ dia após o transplante.

\begin{tabular}{|c|c|c|c|}
\hline \multirow{2}{*}{$\begin{array}{c}\text { Fósforo } \\
\mathrm{mg} / \mathrm{l}\end{array}$} & \multicolumn{3}{|c|}{ Capins } \\
\cline { 2 - 4 } & $\mathrm{IZ}-1$ & brizantha & decumbens \\
\hline 0,1 & $0,07 \mathrm{bA}$ & $0,06 \mathrm{bA}$ & $0,07 \mathrm{bA}$ \\
\hline 1,0 & $0,14 \mathrm{bA}$ & $0,13 \mathrm{bA}$ & $0,10 \mathrm{bA}$ \\
\hline 10,0 & $0,39 \mathrm{aB}$ & $0,72 \mathrm{aA}$ & $0,39 \mathrm{aB}$ \\
\hline
\end{tabular}

C.V. $=39,4 \%$

DMS - Tukey a $5 \%$ para média das espécies e das doses $=0,09$

Letras maiúsculas diferentes em cada linha e letras minúsculas diferentes em cada coluna, indicam diferença significativa ao nível de $5 \%$ de probabilidade. 
No material colhido aos $28^{\underline{0}}$ dias após o transplante houve diferença significativa no teor de fósforo na parte aérea das plantas apenas na dose mais alta de fósforo. Nessa condição, a Brachiaria brizantha foi superior às outras duas espécies estudadas.

As figuras 10, 11 e 12 ilustram as interações verificadas nos três períodos, para as espécies, nas doses de fósforo estudadas. As espécies responderam ao aumento nas doses de fósforo mostrando efeito linear, para cada uma das três forrageiras, nos três períodos, na concentração do nutriente no tecido da parte aérea.

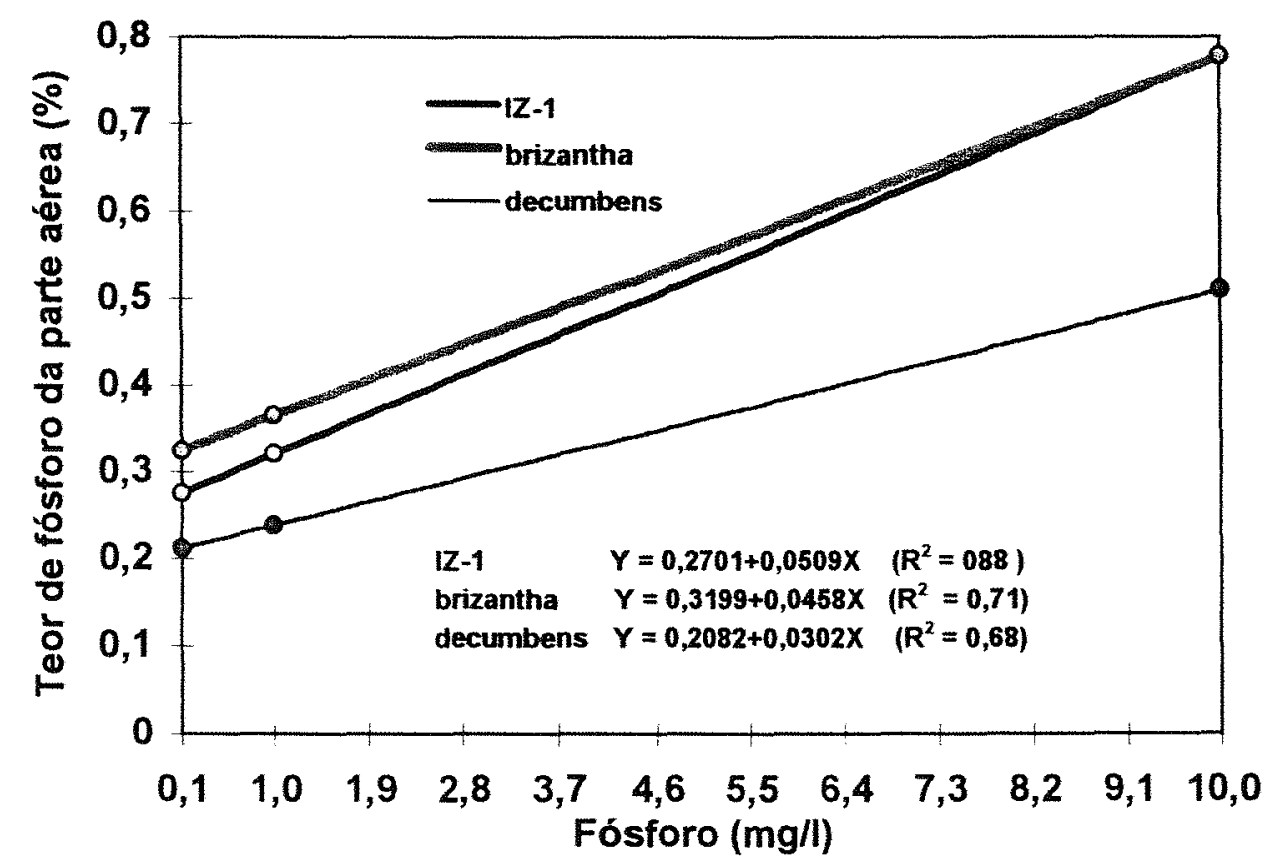

Figura 10. Teor de fósforo $(\%)$, em duas plantas, na parte aérea submetidas a doses de fósforo, em três espécies forrageiras no $14^{\circ}$ dia após o transplante. 
Os teores de fósforo observados na parte aérea situaram-se acima daqueles observados por ARROYO-AGUILU \& COWARD-LORD (1974) com braquiária e por MEIRELLES et al. (1988) e CORREAA (1991) com capim-colonião.

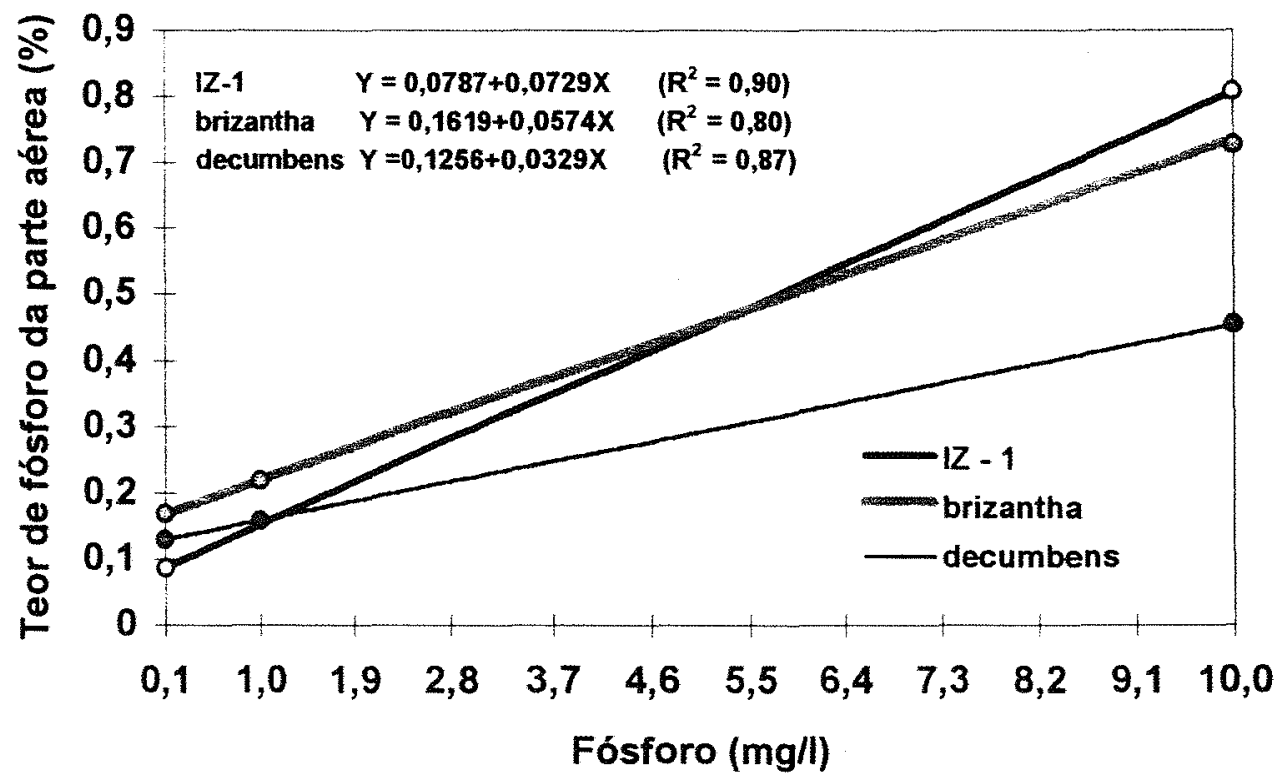

Figura 11. Teor de fósforo (\%), em duas plantas, na parte aérea submetidas a doses de fósforo, em três espécies forrageiras no $21^{0}$ dia após o transplante. 


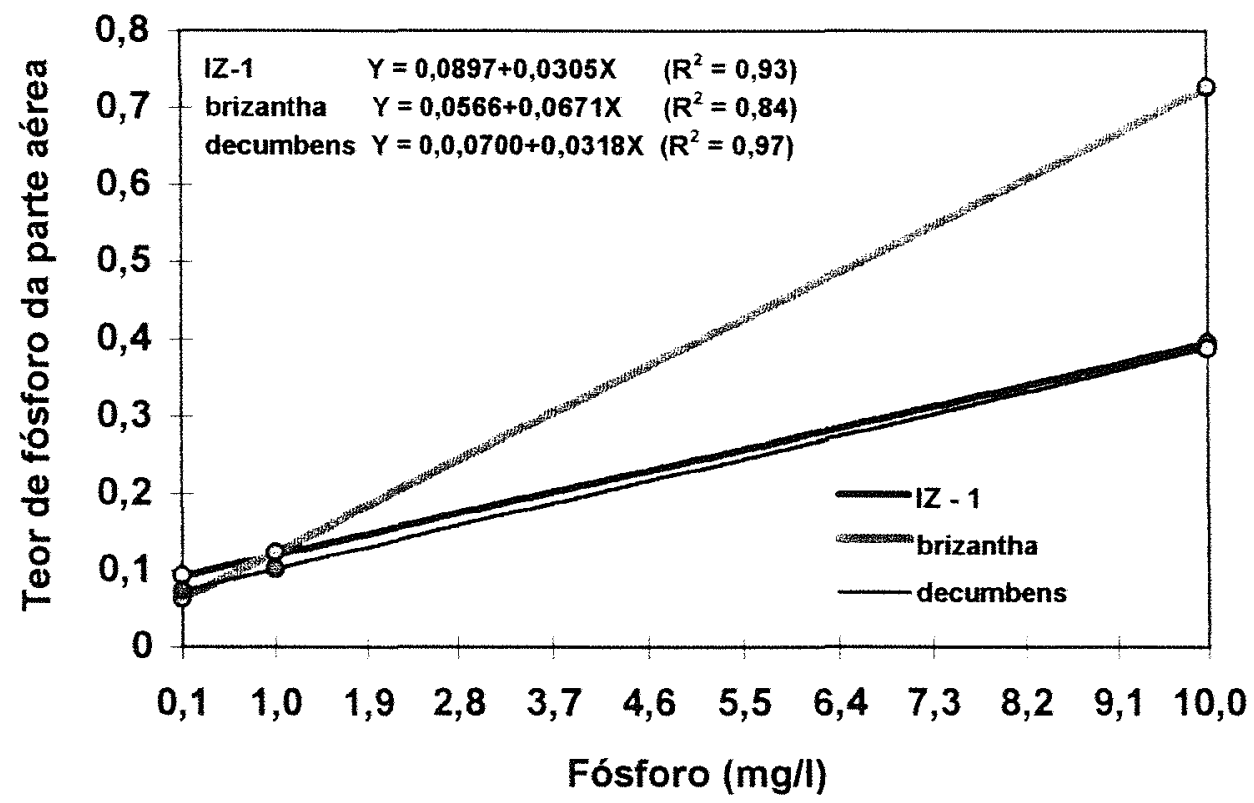

Figura 12. Teor de fósforo (\%), em duas plantas, na parte aérea submetidas a doses de fósforo, em três espécies forrageiras no $28^{0}$ dia após o transplante.

\subsubsection{4 - Conteúdo de fósforo da parte aérea}

A interação entre espécies e doses de fósforo foi significativa $(\mathrm{P}<0,05)$ para o conteúdo de fósforo na parte aérea dos capins, nas três épocas de colheitas estudadas (tabelas 13, 14 e 15). 
Tabela 13. Conteúdo de fósforo (mg/duas plantas) na parte aérea dos três capins submetidas a doses de fósforo, por ocasião do $14^{\underline{0}}$ dia após o transplante.

\begin{tabular}{|c|c|c|c|}
\hline \multirow{2}{*}{$\begin{array}{c}\text { Fósforo } \\
\mathrm{mg} / \mathrm{l}\end{array}$} & \multicolumn{3}{|c|}{ Capins } \\
\cline { 2 - 4 } & $\mathrm{IZ}-1$ & brizantha & decumbens \\
\hline 0,1 & $0,29 \mathrm{cA}$ & $0,22 \mathrm{cA}$ & $0,11 \mathrm{cB}$ \\
\hline 1,0 & $0,73 \mathrm{bA}$ & $0,61 \mathrm{bAB}$ & $0,43 \mathrm{bB}$ \\
\hline 10,0 & $1,67 \mathrm{aA}$ & $1,16 \mathrm{aB}$ & $0,37 \mathrm{aC}$ \\
\hline
\end{tabular}

C.V. $=20,3 \%$

DMS - Tukey a $5 \%$ para média das espécies e das doses $=0,13$

Letras maiúsculas diferentes em cada linha e letras minúsculas diferentes em cada coluna, indicam diferença significativa ao nível de $5 \%$ de probabilidade.

Tabela 14. Conteúdo de fósforo (mg/duas plantas) na parte aérea dos três capins submetidas a doses de fósforo, por ocasião do $21^{\circ}$ dia após o transplante.

\begin{tabular}{|c|c|c|c|}
\hline \multirow{2}{*}{$\begin{array}{c}\text { Fósforo } \\
\mathrm{mg} / \mathrm{l}\end{array}$} & \multicolumn{3}{|c|}{ Capins } \\
\cline { 2 - 4 } & $\mathrm{IZ}-1$ & brizantha & decumbens \\
\hline 0,1 & $0,25 \mathrm{bA}$ & $0,32 \mathrm{bA}$ & $0,18 \mathrm{cA}$ \\
\hline 1,0 & $0,59 \mathrm{bAB}$ & $0,99 \mathrm{bA}$ & $0,53 \mathrm{bB}$ \\
\hline 10,0 & $6,24 \mathrm{aA}$ & $3,09 \mathrm{aAB}$ & $1,72 \mathrm{aB}$ \\
\hline
\end{tabular}

C.V. $=56,7 \%$

DMS - Tukey a $5 \%$ para média das espécies das doses $=0,89$

Letras maiúsculas diferentes em cada linha e letras minúsculas diferentes em cada coluna, indicam diferença significativa ao nivel de $5 \%$ de probabilidade. 
Tabela 15. Conteúdo de fósforo $(\mathrm{mg} /$ duas plantas) na parte aérea dos três capins submetidas a doses de fósforo, por ocasião do $28^{\underline{0}}$ dia após o transplante.

\begin{tabular}{|c|c|c|c|}
\hline \multirow{2}{*}{$\begin{array}{c}\text { Fósforo } \\
\mathrm{mg} / 1\end{array}$} & \multicolumn{3}{|c|}{ Capins } \\
\cline { 2 - 4 } & $\mathrm{IZ}-1$ & brizantha & decumbens \\
\hline 0,1 & $0,51 \mathrm{cA}$ & $0,31 \mathrm{bC}$ & $0,43 \mathrm{bB}$ \\
\hline 1,0 & $1,84 \mathrm{bA}$ & $0,98 \mathrm{bB}$ & $0,93 \mathrm{bB}$ \\
\hline 10,0 & $6,24 \mathrm{aA}$ & $10,68 \mathrm{aA}$ & $6,13 \mathrm{aA}$ \\
\hline
\end{tabular}

C.V. $=49,5 \%$

DMS - Tukey a $5 \%$ para média das espécies e das doses $=1,57$

Letras maiúsculas diferentes em cada linha e letras minúsculas diferentes em cada coluna, indicam diferença significativa ao nível de $5 \%$ de probabilidade.

A tabela 13, mostra significância para a diferença entre as espécies na época de 14 dias do transplante, para o conteúdo de fósforo na parte aérea. A decumbens mostrou menor conteúdo de fósforo que o IZ-1 e a brizantha na dose mais baixa $(0,1 \mathrm{mg} / \mathrm{l})$ e mais alta $(10,0 \mathrm{mg} / \mathrm{l})$ de fósforo. Para a dose $1,0 \mathrm{mg} / \mathrm{l}$, a decumbens apresentou menor conteúdo de fósforo em relação ao IZ-1, não diferindo da brizantha. 


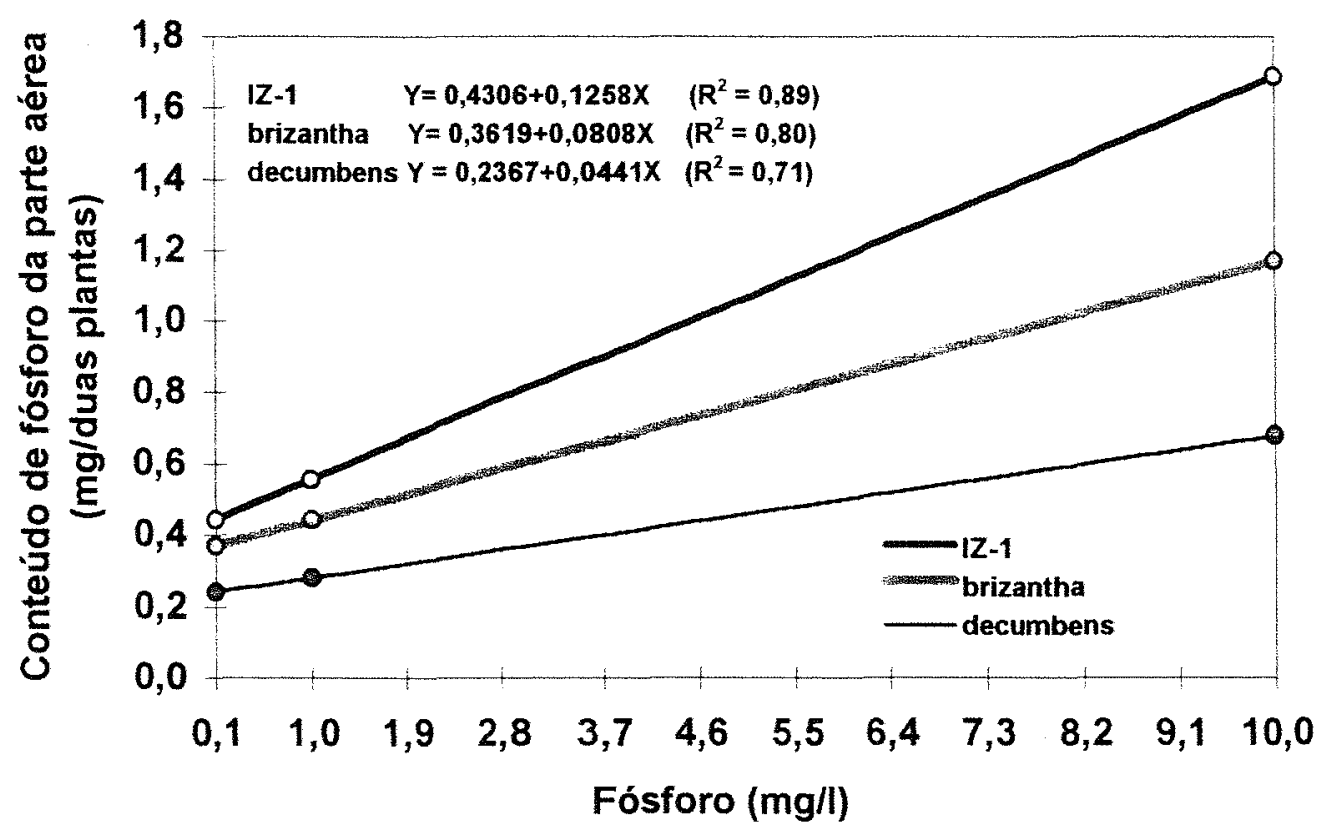

Figura 13. Conteúdo de fósforo ( $\mathrm{mg} /$ duas plantas) na parte aérea submetidas a doses de fósforo, em três espécies forrageiras no $14^{\circ}$ dia após o transplante.

Para o período de 21 dias do transplante a Brachiaria decumbens apresentou menor conteúdo na dose 1,0 mg/l quando comparada com a brizantha e no 10,0 mg/l quando comparada com o IZ - 1 (tabela 14). O IZ-1 e a brizantha não diferiram significativamente nessa época, em qualquer das doses de fósforo na solução. 
No $28^{\underline{0}}$ dia a espécie Panicum maximum apresentou conteúdo maior que as outras duas espécies nas doses 0,1 e $1,0 \mathrm{mg} / \mathrm{l}$, sendo que a brizantha diferiu da decumbens na dose mais baixa $(0,1 \mathrm{mg} / \mathrm{l})$ de fósforo. Para a dose mais alta não houve diferenças significativas entre as três espécies forrageiras (tabela 15).

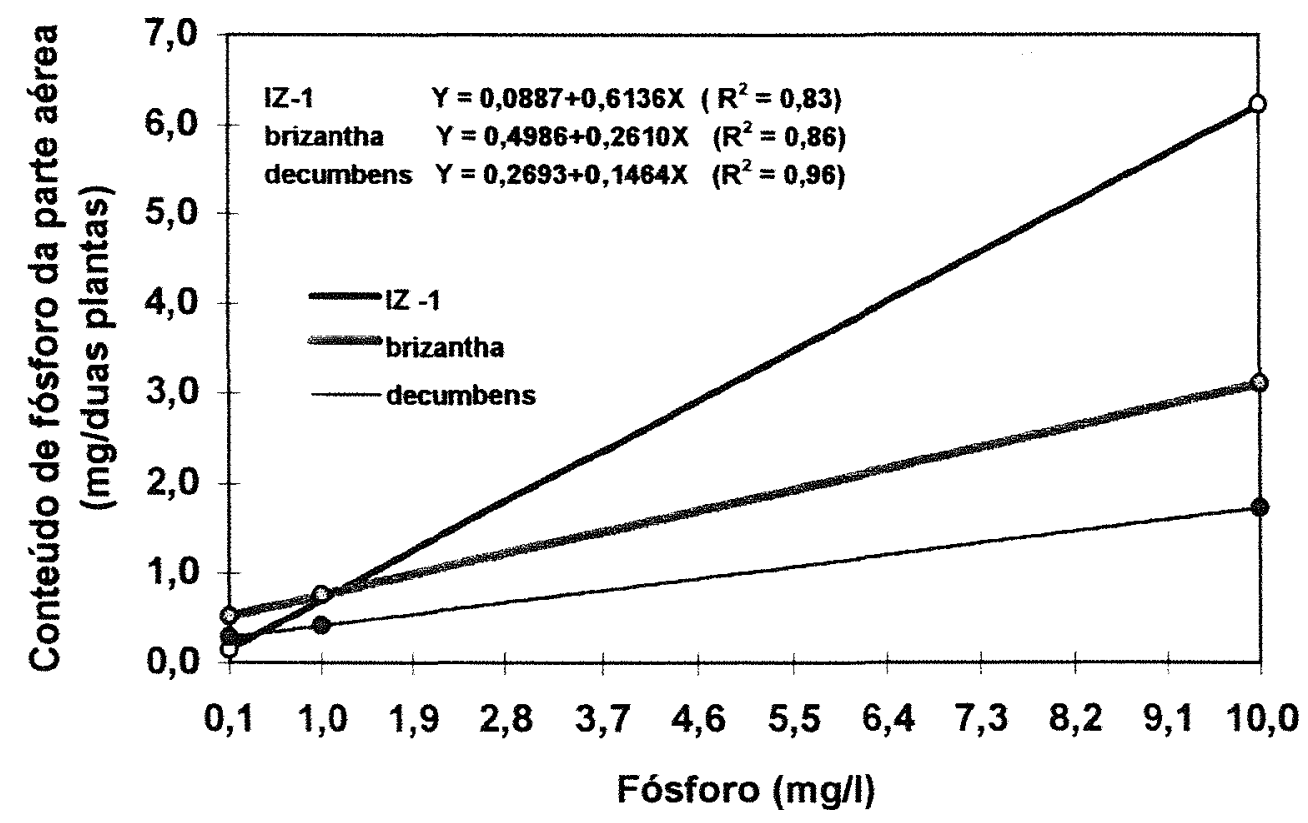

Figura 14. Conteúdo de fósforo (mg/duas plantas) na parte aérea submetidas a doses de fósforo, em três espécies forrageiras no $21^{\circ}$ dia após o transplante.

O conteúdo de fósforo nas forrageiras aumentou conforme ocorreu a elevação das doses de fósforo, estando isto ilustrado nas figuras 13 , 14 e 15 . 
As espécies apresentaram, no três períodos estudados, elevação no conteúdo de fósforo da parte aérea, segundo modelo linear, A Brachiaria decumbens sempre mostrou menor conteúdo de fósforo que as outras duas espécies estudadas e a diferença no valor dessa variável entre a decumbens e as outras gramíneas foi maior quanto mais elevada era a dose de fósforo na solução.

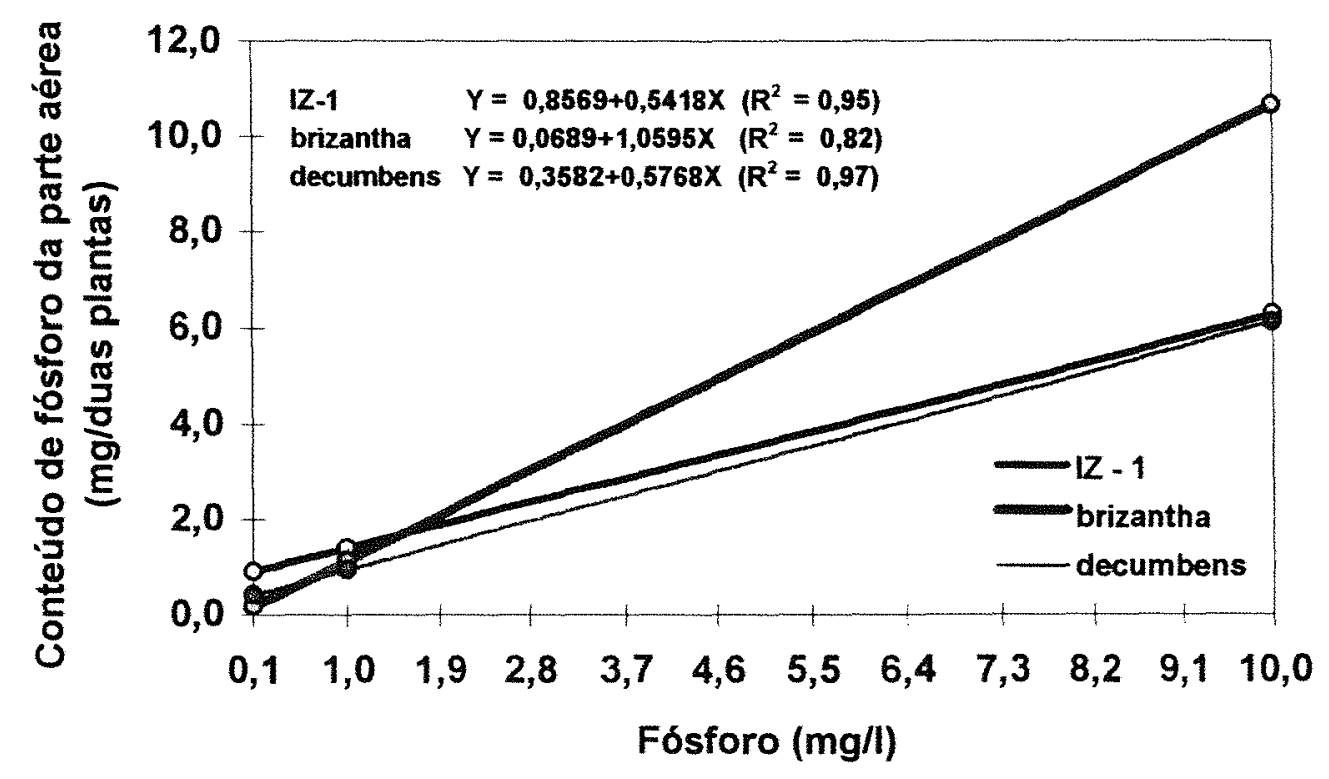

Figura 15. Conteúdo de fósforo (mg/duas plantas) na parte aérea submetidas a doses de fósforo, em três espécies forrageiras no $28^{\underline{0}}$ dia após o transplante. 


\subsubsection{5 - Atividade de fosfatase ácida no tecido foliar}

$\mathrm{Na}$ atividade de fosfatase ácida verificou-se interação significativa entre as espécies e as doses de fósforo, nos três períodos estudados, como mostram as tabelas 16,17 e 18 .

Tabela 16. Atividade de fosfatase ácida $(\mu \mathrm{M} \mathrm{pNPP} / \mathrm{h} / \mathrm{g}$ de tecido foliar fresco), em duas plantas, nos três capins submetidas a doses de fósforo, por ocasião do $14^{\circ}$ dia após o transplante.

\begin{tabular}{|c|c|c|c|}
\hline \multirow{2}{*}{$\begin{array}{c}\text { Fósforo } \\
\mathrm{mg} / 1\end{array}$} & \multicolumn{3}{|c|}{ Capins } \\
\cline { 2 - 4 } & $\mathrm{IZ}-1$ & brizantha & decumbens \\
\hline 0,1 & $79,46 \mathrm{aB}$ & $139,55 \mathrm{aA}$ & $119,62 \mathrm{aA}$ \\
\hline 1,0 & $61,83 \mathrm{bB}$ & $91,15 \mathrm{bA}$ & $52,83 \mathrm{bB}$ \\
\hline 10,0 & $28,21 \mathrm{cB}$ & $45,10 \mathrm{cA}$ & $39,44 \mathrm{bAB}$ \\
\hline
\end{tabular}

C.V. $=9,8 \%$

DMS - Tukey a $5 \%$ para média das espécies e das doses $=7,31$

Letras maiúsculas diferentes em cada linha e letras minúsculas diferentes em cada coluna indicam diferença significativa ao nível de $5 \%$ de probabilidade.

Para a atividade de fosfatase ácida, no período de 14 dias do transplante, as braquiárias apresentaram valores significativamente mais elevados que o Panicum maximum na dose mais baixa de fósforo na solução. Para as outras duas doses de fósforo, a brizantha diferiu do IZ-1 e da decumbens na dose $1,0 \mathrm{mg} / \mathrm{l}$ e na maior dose apenas do IZ-1, mostrando uma maior necessidade de fósforo nestes primeiros 14 dias após o transplante (tabela 16). 
Tabela 17. Atividade de fosfatase ácida $(\mu \mathrm{M} \mathrm{pNPP} / \mathrm{h} / \mathrm{g}$ de tecido foliar fresco), em duas plantas, nos três capins submetidas a doses de fósforo no $21^{\circ}$ dia após o transplante.

\begin{tabular}{|c|c|c|c|}
\hline \multirow{2}{*}{$\begin{array}{c}\text { Fósforo } \\
\mathrm{mg} / \mathrm{l}\end{array}$} & \multicolumn{3}{|c|}{ Capins } \\
\hline & IZ-1 & brizantha & decumbens \\
\hline 0,1 & 247,03 aA & $234,74 \mathrm{aA}$ & 277,37 aA \\
\hline 1,0 & $127,00 \mathrm{bA}$ & $125,73 \mathrm{bA}$ & $97,67 \mathrm{bB}$ \\
\hline 10,0 & $66,79 \mathrm{cB}$ & $85,20 \mathrm{cA}$ & $72,77 \mathrm{cAB}$ \\
\hline
\end{tabular}

C.V. $=8,5 \%$

DMS - Tukey a $5 \%$ para média das espécies e das doses $=12,87$

Letras maiúsculas diferentes em cada linha e letras minúsculas diferentes em cada coluna indicam diferença significativa ao nível de $5 \%$ de probabilidade.

Tabela 18. Atividade de fosfatases ácida $(\mu \mathrm{M} \mathrm{pNPP} / \mathrm{h} / \mathrm{g}$ de tecido foliar fresco), em duas plantas, nos três capins submetidas a doses de fósforo por ocasião do $28^{\underline{0}}$ dia do transplante.

\begin{tabular}{|c|r|c|c|}
\hline \multirow{2}{*}{$\begin{array}{c}\text { Fósforo } \\
\mathrm{mg} / 1\end{array}$} & \multicolumn{3}{|c|}{ Capins } \\
\cline { 2 - 4 } & $\mathrm{IZ}-1$ & brizantha & decumbens \\
\hline 0,1 & $396,04 \mathrm{aA}$ & $309,22 \mathrm{aB}$ & $371,42 \mathrm{aA}$ \\
\hline 1,0 & $197,67 \mathrm{bA}$ & $202,75 \mathrm{bA}$ & $152,02 \mathrm{bB}$ \\
\hline 10,0 & $84,28 \mathrm{cB}$ & $151,58 \mathrm{cA}$ & $58,53 \mathrm{cC}$ \\
\hline
\end{tabular}

C.V. $=7,3 \%$

DMS - Tukey a $5 \%$ para média das espécies e das doses $=15,96$

Letras maiúsculas diferentes em cada linha e letras minúsculas diferentes em cada coluna indicam diferença significativa ao nível de $5 \%$ de probabilidade.

No $21^{\circ}$ dia após o transplante, a Brachiaria brizantha e o Panicum maximum apresentaram valores mais elevados na atividade dessas 
enzimas que a Brachiaria decumbens, somente na dose $1,0 \mathrm{mg} / \mathrm{l}$. Para a dose $10,0 \mathrm{mg} / 1$ a brizantha diferiu apenas do IZ - 1, apresentando valores semelhantes à decumbens (tabela 17).

No $28^{\mathrm{o}}$ dia após o transplante detectaram-se diferenças significativas entre espécies, nas três doses de fósforo estudadas. Para a dose $0,1 \mathrm{mg} / 1$ a brizantha apresentou menor valor na atividade, em relação às outras duas espécies. $\mathrm{Na}$ dose $1,0 \mathrm{mg} / \mathrm{l}$ foi a decumbens que apresentou o menor valor, enquanto na dose de $10,0 \mathrm{mg} / 1$ as três espécies diferiram entre si, sendo o maior valor para a brizantha, seguida pelo IZ - 1 e por último a decumbens.

A Brachiaria decumbens, para os três períodos de colheita, sempre se situou entre os mais elevados valores para a atividade de fosfatase ácida, na dose mais baixa de fósforo. Quando se incrementou a dose de fósforo na solução a atividade enzimática diminuiu acentuadamente. PEREIRA (1986) afirmou que a braquiárias são capazes de vegetar com baixos teores de fósforo disponível, o que não ocorreu com a Brachiaria brizantha.

Em termos de doses de fósforo não se encontrou diferença significativa somente no período de 14 dias após o transplante para a Brachiaria decumbens nas doses de 1,0 para 10,0 mg/1. Existe uma queda da atividade de fosfatase ácida com o aumento nas doses de fósforo na solução, o que permite visualizar o seu uso como critério para avaliar o estado nutricional e o grau de deficiência de fósforo nessas forrageiras, como verificado em outras plantas ( McLACHLAN \& DE MARCO, 1982). 
Quando considerada a correlação da produção de matéria seca da parte aérea com a atividade de fosfatase ácida nota-se que a mesma sempre foi negativa e teve elevados coeficientes. O IZ-1 mostrou maior coeficiente de correlação $(r=-0,97)$, seguido pela decumbens $(r=-0,89)$ e pela brizantha $(\mathrm{r}=-0,87)$.

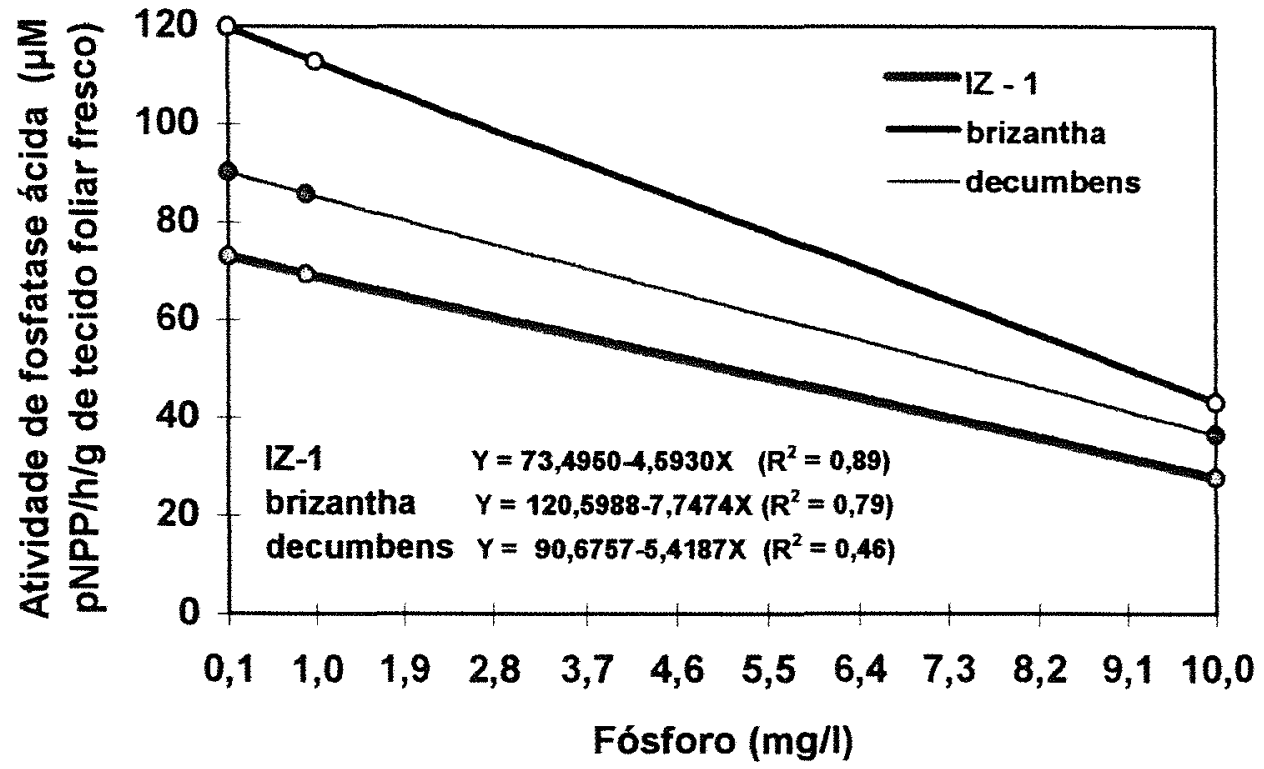

Figura 16. Atividade de fosfatase ácida ( $\mu \mathrm{M} \mathrm{pNPP/h} / \mathrm{g}$ tecido foliar fresco), em duas plantas, nas três forrageiras submetidas a três doses de fósforo, por ocasião do $14^{\circ}$ dia após o transplante.

A correlação para teor de fósforo e essa atividade enzimática mostrou que o IZ-1 também teve o maior coeficiente $(r=-0,86)$ e foi seguido também pela decumbens $(\mathrm{r}=-0,72)$. A relação dessa atividade com os teores de fósforo revelou que o IZ-1 apresentou maior correlação $(r=-0,82)$ que a brizantha $(r=-0,79)$ e a decumbens $(r=-0,78)$. Para perfilhos as correlações 
apresentaram elevados coeficientes e corresponderam a $r=-0,97$ no IZ-1, a $r=-0,95$ na brizantha e a $r=-0,92$ na decumbens.

Pelos resultados obtidos na correlação o Panicum maximum mostrou ser a melhor espécie das três estudadas, para avaliar o estado nutricional da planta em termos de fósforo.

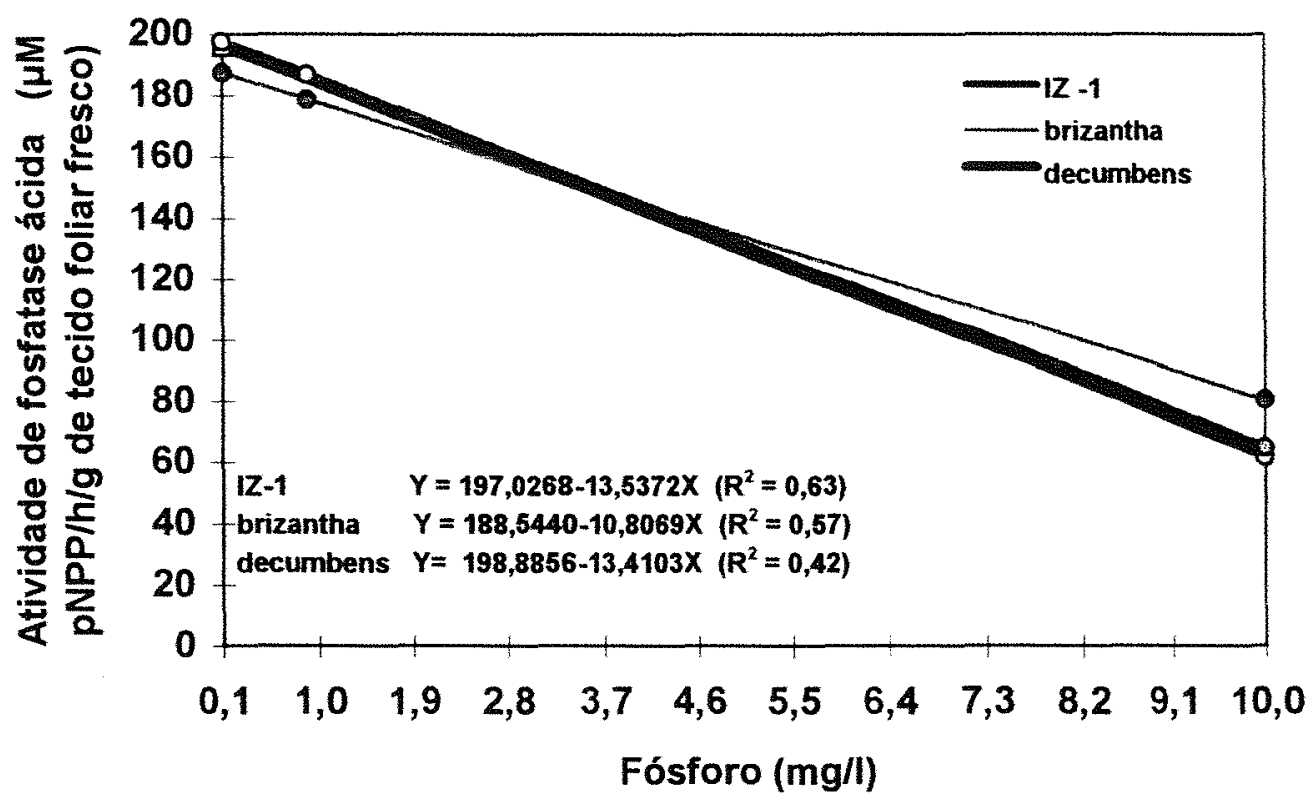

Figura 17. Atividade de fosfatase ácida $(\mu \mathrm{M} \mathrm{pNPP} / \mathrm{h} / \mathrm{g}$ tecido foliar fresco), em duas plantas, nas três forrageiras submetidas a três doses de fósforo, por ocasião do $21^{\circ}$ dia após o transplante. 
Pelos resultados obtidos na correlação, o Panicum maximum mostrou-se uma promissora (espécie das três estudadas) para avaliar o estado nutricional da planta, em termos de fósforo.

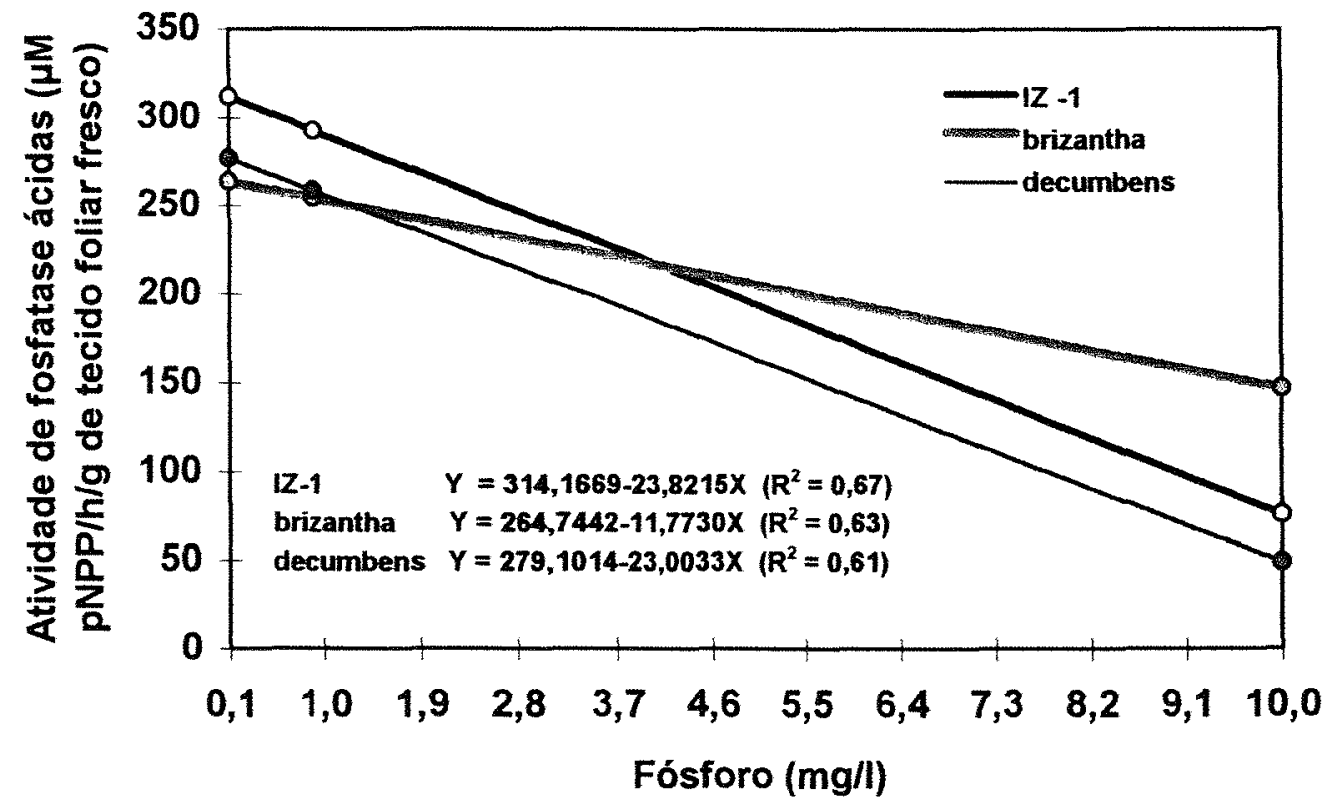

Figura 18. Atividade de fosfatase ácida $(\mu \mathrm{M} \mathrm{pNPP} / \mathrm{h} / \mathrm{g}$ tecido foliar fresco), em duas plantas, submetidos a três doses de fósforo com três forrageiras no $28^{\circ}$ dia após o transplante. 


\subsection{Casa-de-Vegetação}

\subsubsection{Primeiro corte}

\subsubsection{Número de perfilhos}

O número de perfilhos contados na época da colheita foi influenciado significativamente pela interação entre as doses de fósforo e as espécies estudadas, como mostra a tabela 19.

Tabela 19. Número de perfilhos por vaso, em cinco plantas, nos três capins submetidos a doses de fósforo na solução nutritiva, por ocasião do primeiro corte das plantas.

\begin{tabular}{|c|r|c|c|}
\hline \multirow{2}{*}{$\begin{array}{c}\text { Fósforo } \\
\mathrm{mg} / 1\end{array}$} & \multicolumn{3}{|c|}{ Capins } \\
\cline { 2 - 4 } & $\mathrm{IZ}-1$ & brizantha & decumbens \\
\hline 3,1 & $5,50 \mathrm{cB}$ & $10,25 \mathrm{cA}$ & $11,50 \mathrm{cA}$ \\
\hline 15,5 & $9,50 \mathrm{bB}$ & $21,00 \mathrm{bA}$ & $20,50 \mathrm{bA}$ \\
\hline 31,0 & $14,00 \mathrm{aB}$ & $24,00 \mathrm{aA}$ & $25,00 \mathrm{aA}$ \\
\hline
\end{tabular}

C.V. $=8,8 \%$

DMS - Tukey a $5 \%$ para média das espécies e das doses $=1,40$

Letras maiúsculas diferentes em cada linha e letras minúsculas diferentes em cada coluna indicam diferença significativa ao nivel de $5 \%$ de probabilidade.

A brizantha e a decumbens obtiveram maior número de perfilhos que o IZ-1, nas três doses estudadas. Possivelmente em condições de 
temperatura e umidade controladas o Panicum maximum perfilha mais ou utiliza melhor o fósforo, já que este nutriente desempenha, segundo WERNER (1986), importante papel no perfilhamento inicial das gramíneas forrageiras.

Para as doses de fósforo, as três espécies responderam ao aumento no suprimento de fósforo, como mostra a figura 19.

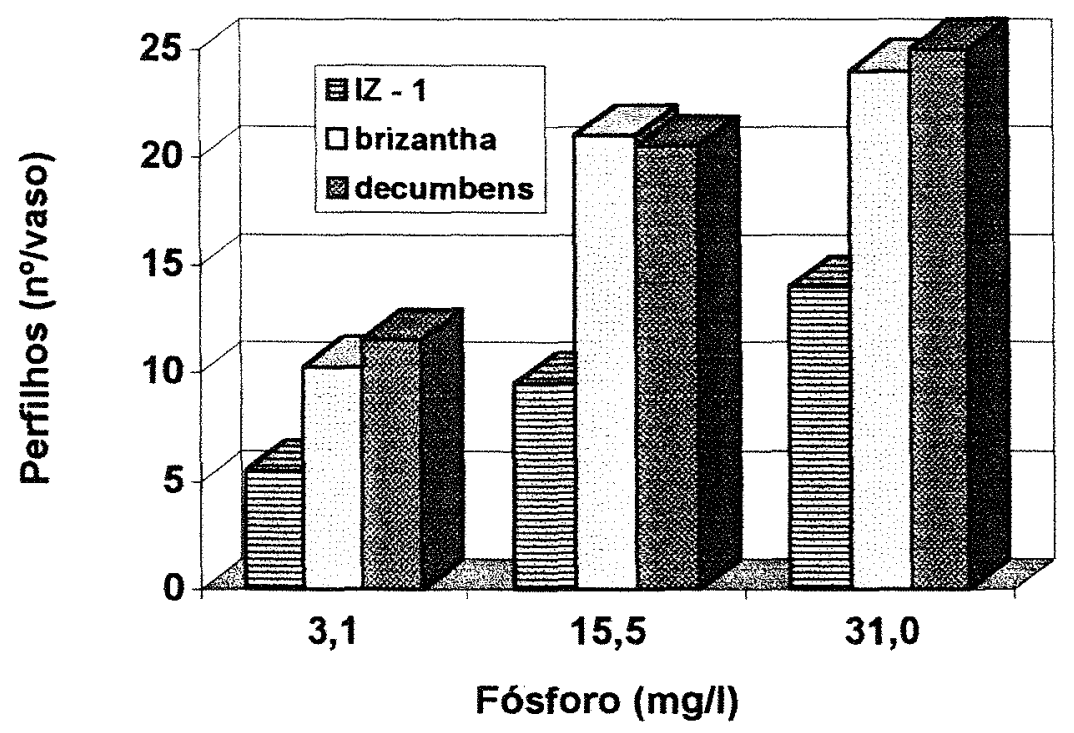

Figura 19. Número de perfilhos por vaso, cinco plantas, em três espécies de forrageiras submetidas a doses de fósforo, por ocasião do primeiro corte das plantas. 


\subsubsection{Produção de matéria seca da parte aérea}

A produção de matéria seca da parte aérea foi influenciada significativamente pela interação entre as doses de fósforo e as espécies estudadas, conforme ilustra a tabela 20 .

Tabela 20. Produção de matéria seca da parte aérea ( $\mathrm{g} / \mathrm{vaso}$ ), média de quatro repetições, em três capins submetidos a doses de fósforo na solução nutritiva, por ocasião do primeiro corte das plantas.

\begin{tabular}{|c|c|c|c|}
\hline \multirow{2}{*}{$\begin{array}{c}\text { Fósforo } \\
\mathrm{mg} / 1\end{array}$} & \multicolumn{3}{|c|}{ Capins } \\
\cline { 2 - 4 } & $\mathrm{IZ}-1$ & brizantha & decumbens \\
\hline 3,1 & $4,79 \mathrm{bA}$ & $2,34 \mathrm{bB}$ & $1,73 \mathrm{bB}$ \\
\hline 15,5 & $12,58 \mathrm{aA}$ & $7,05 \mathrm{aB}$ & $6,42 \mathrm{aB}$ \\
\hline 31,0 & $16,34 \mathrm{aA}$ & $8,29 \mathrm{aA}$ & $9,52 \mathrm{aB}$ \\
\hline
\end{tabular}

C.V. $=20,2 \%$

DMS - Tukey a $5 \%$ para média das espécies e das doses $=15,8$

Letras maiúsculas diferentes em cada linha e letras minúsculas em cada coluna indicam diferença significativa ao nível de $5 \%$ de probabilidade.

Os valores mostram diferenças significativas do Panicum maximum em relação às duas braquiárias, nas três doses estudadas. ARAGÃO et al.(1981) observaram, em solo Podzólico Vermelho - Escuro, maior resposta na produção de matéria seca com o Panicum maximum, quando comparados com a Brachiaria brizantha e a Brachiaria decumbens.

Para as doses de fósforo na solução verificou-se um aumento significativo da produção de matéria seca da parte aérea, como mostra a figura 20 . 


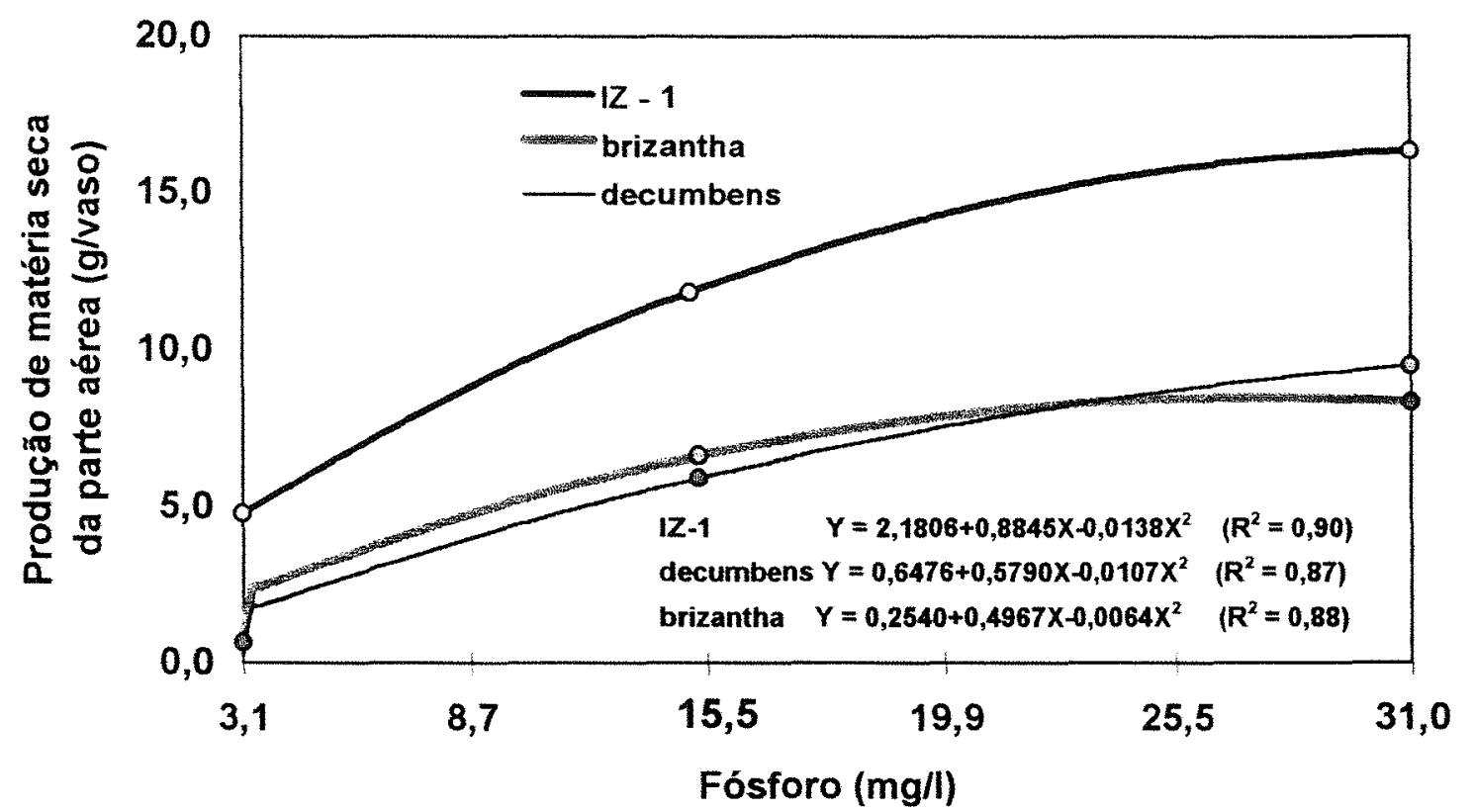

Figura 20. Produção de matéria seca da parte aérea (g/vaso), média de quatro repetições, em três espécies forrageiras submetidas a doses de fósforo, por ocasião do primeiro corte das plantas.

As três espécies responderam às doses de fósforo estudadas. No entanto, a brizantha apresentou ponto de máximo próximo da dose $25,0 \mathrm{mg} /$, enquanto as outras duas espécies responderam até a dose mais alta do fósforo estudado. Vários autores, como MARTINEZ \& HAAG (1980) e FURLANI \& USBERTI FILHO (1990), observaram aumento na produção de matéria seca em capim-colonião, com o aumento nas doses de fósforo. CORRÊA (1991), constatou também respostas expressivas na produção de matéria seca do capim Panicum maximum à adubação fosfatada, em experimentos em casa-de-vegetação. 


\subsubsection{Teor de fósforo da parte aérea}

O teor de fósforo variou significativamente $(\mathrm{P}<0,05)$ entre as espécies, mostrando valores mais altos para a brizantha $(0,13 \%)$, em relação ao IZ-1 $(0,09 \%)$ e à decumbens $(0,10 \%)$. O Panicum maximum e a Brachiaria decumbens não diferiram significativamente entre si.

Para as doses de fósforo na solução verificou-se resposta significativa $(\mathrm{P}<0,05)$ em termos de teor de fósforo no tecido das forrageiras, sendo lineares com a elevação nas doses de fósforo,como mostra a figura 21.

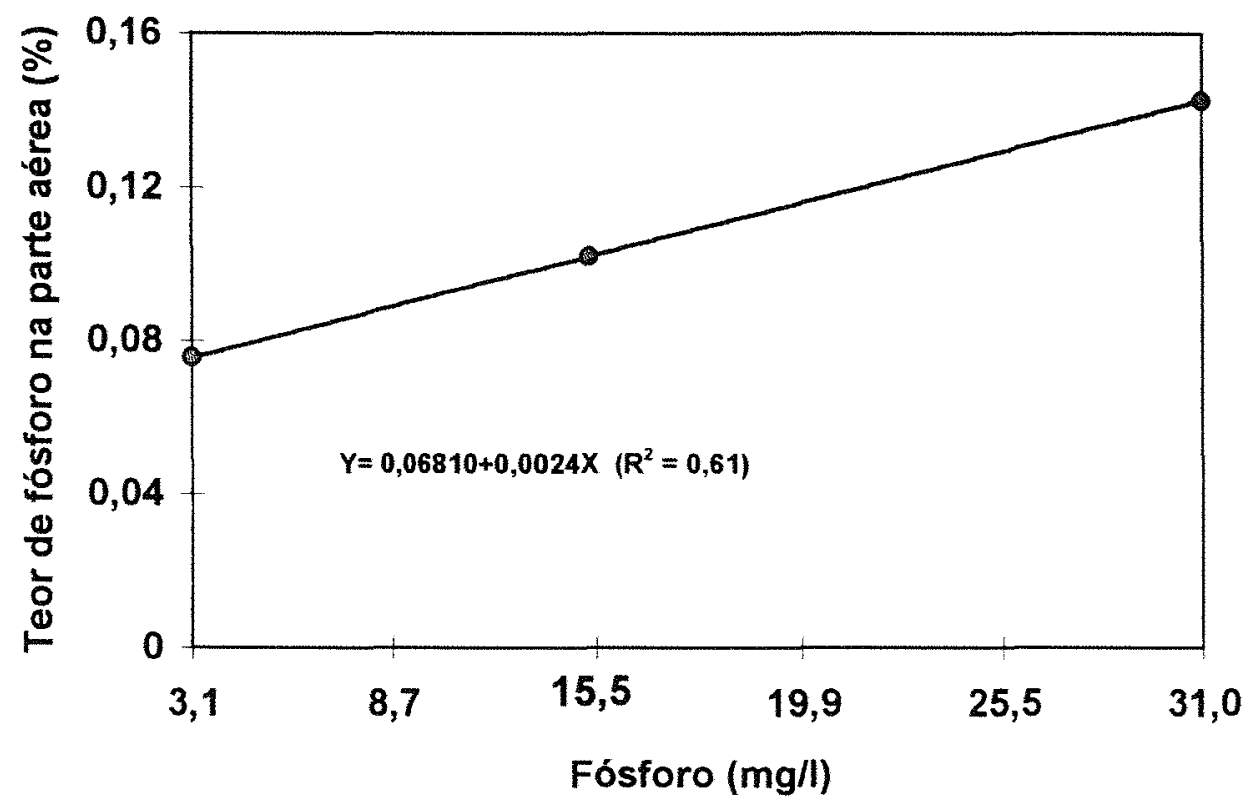

Figura 21. Teor de fósforo na parte aérea (\%), média de quatro repetições, em três espécies forrageiras submetidas a doses de fósforo, por ocasião do primeiro corte das plantas. 
GONÇALVES \& OLIVEIRA (1982), mostraram resultados semelhantes aos encontrados nesse estudo, onde as concentrações de fósforo aumentaram com níveis mais altos de fósforo nas braquiárias. MARTINEZ \& HAAG (1980) mostraram aumentos lineares na concentração de fósforo com a elevação dos níveis de fósforo no substrato, onde cultivaram Panicum maximum.

\subsubsection{Conteúdo de fósforo da parte aérea}

Foram observadas diferenças significativas $(P<0,05)$ entre as espécies para o conteúdo de fósforo na parte aérea . O IZ-1 mostrou o maior valor $(12,23 \mathrm{mg}$ de $\mathrm{P} /$ vaso $)$ em relação à brizantha $(8,29 \mathrm{mg}$ de $\mathrm{p} / \mathrm{vaso}) \mathrm{e}$ decumbens ( $6,96 \mathrm{mg}$ de $\mathrm{P} / \mathrm{vaso})$. As braquiárias não diferiram entre si.

Para as doses de fósforo ocorreram aumentos significativos $(\mathrm{P}<0,05)$ no conteúdo de fósforo nas plantas, conforme o aumento nas doses de fósforo na solução nutritiva, como mostra a figura 22.

FURLANI \& USBERTI FILHO (1990) observaram aumentos significativos no conteúdo de fósforo com o aumento nos níveis de fósforo em onze genótipos de Panicum maximum. 


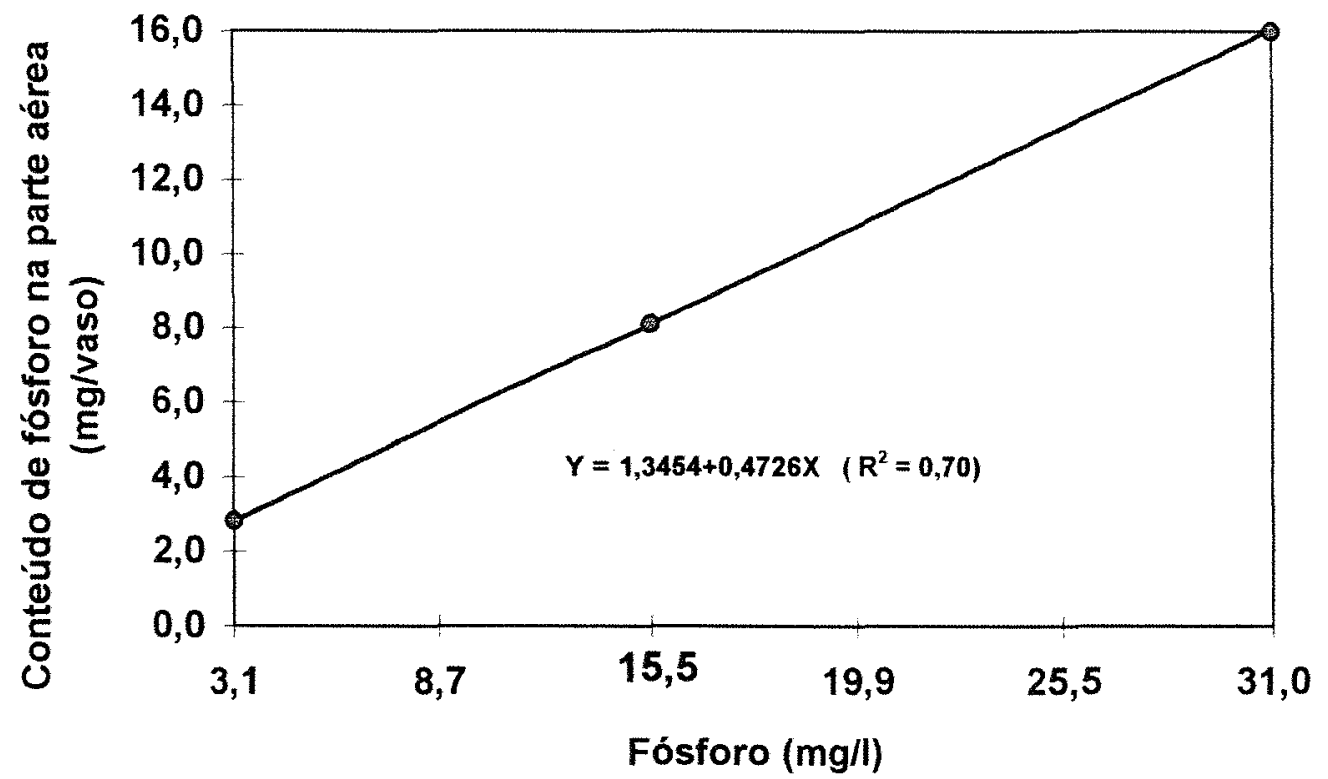

Figura 22. Conteúdo de fósforo na parte aérea ( $\mathrm{mg} /$ cinco plantas), média de quatro repetições, submetidas a doses de fósforo, por ocasião do primeiro corte das plantas.

\subsubsection{Atividade de fosfatase ácida no tecido foliar}

A atividade de fosfatase ácida apresentou diferenças significativas entre as espécies, mostrando valores mais elevados para a brizantha, seguida da decumbens e do IZ-1 como mostra a tabela 21 . 
Tabela 21. Concentração de fósforo (\%), conteúdo de fósforo (mg/vaso) e atividade de fosfatase ácida $(\mu \mathrm{M} \mathrm{pNPP} / \mathrm{h} / \mathrm{g}$ de tecido vegetal fresco), média de quatro repetições, nos três capins submetidos a doses de fósforo na solução nutritiva, por ocasião do primeiro corte.

\begin{tabular}{|c|c|c|c|}
\hline Capins & $\begin{array}{c}\text { Teor de } \\
\mathrm{P}(\%)\end{array}$ & $\begin{array}{c}\text { Coteúdo de } \mathrm{P} \\
(\mathrm{mg} / \text { vaso })\end{array}$ & $\begin{array}{c}\text { Atividade de fosfatase ácida } \\
(\mu \mathrm{g} \mathrm{pNPP} / \mathrm{h} / \mathrm{g} \text { de matéria } \\
\text { fresca })\end{array}$ \\
\hline $\mathrm{IZ}-1$ & $0,09 \mathrm{~B}$ & $12,23 \mathrm{~A}$ & $64,57 \mathrm{C}$ \\
\hline brizantha & $0,13 \mathrm{~A}$ & $8,29 \mathrm{~B}$ & $222,91 \mathrm{~A}$ \\
\hline decumbens & $0,10 \mathrm{~B}$ & $6,96 \mathrm{~B}$ & $172,52 \mathrm{~B}$ \\
\hline C.V. $(\%)$ & 18,7 & 38,4 & 48,2 \\
\hline
\end{tabular}

DMS - Tukey a $5 \%$ média de espécies e doses para teor de fósforo, conteúdo de fósforo e atividade de fosfatase ácida, respectivamente $=0,02 ; 2,57$ e 23,03

Letras diferentes em cada coluna indicam diferença significativa ao nível de $5 \%$ de probabilidade

A atividade de fosfatase ácida diferiu significativamente $(\mathrm{P}<0,05)$ entre as doses de fósforo estudadas. Quanto mais elevada a dose de fósforo na solução mais baixa foi a atividade enzimática na folha da forrageira, podendo estes resultados, apontar como critério para avaliar o estado nutricional e o grau de deficiência de fósforo (MCLACHLAN \& DE MARCO,1982).

Quando considerada a correlação da produção de matéria seca da parte aérea coma atividade de fosfatase ácida, o IZ-1 apresentou o maior coeficiente de correlação $(r=-0,89)$ seguidos pela decumbens $(r=-0,77)$ e finalmente pela brizantha $(r=-0,74)$. A correlação entre teor de fósforo na parte aérea dos capins e essa atividade enzimática mostrou o IZ-1 com 
coeficiente bem maior $(\mathrm{r}=-0,89)$ e $(\mathrm{r}=-0,53$ e $-0,52)$ para brizantha e decumbens respectivamente. Para dose de fósforo na solução, a correlação com a atividade enzimática revelou que o IZ-1 também apresentou maior correlação $(r=-0,84)$ que a brizantha $(r=-0,77)$ e a decumbens $(r=-0,72)$. Para a correlação de atividade de fosfatase ácida com o número de perfilhos os coeficientes foram: $(\mathrm{r}=-0,81)$ para o IZ-1, $(\mathrm{r}=-0,72)$ para a brizantha $\mathrm{e}$ $(\mathrm{r}=-0,66)$ para a decumbens.

As correlações envolvendo atividade de fosfatase ácida apresentaram coeficientes negativos caracterizando uma relação inversa dessa atividade enzimática com aprodução de matéria seca, o teor de fósforo, o número de perfilhos e a dose de fósforo na solução nutritiva.

\subsubsection{Segundo Corte}

\subsubsection{Número de perfilhos}

$\mathrm{O}$ número de perfilhos nas cinco plantas de cada vaso foi influenciado significativamente pela interação entre as doses de fósforo e espécies, como mostra a tabela 22.

A Brachiaria brizantha apresentou maior número de perfilhos que o Panicum maximum somente na dose $15,5 \mathrm{mg} / 1$. Na dose $31,0 \mathrm{mg} / \mathrm{l} \mathrm{a}$ Brachiaria decumbens mostrou mais elevado número de perfilhos que o Panicum maximum. Na dose mais baixa de fósforo ( $3,1 \mathrm{mg} / \mathrm{l})$ não houve 
diferença significativa entre as espécies. Neste corte, as braquiárias obtiveram número de perfilhos maior que o Panicum, nas doses 15,5 e $31,0 \mathrm{mg} / 1$.

Para as doses de fósforo na solução as três espécies responderam ao aumento no suprimento de fósforo, como mostra a figura 23.

Tabela 22. Número de perfilhos por vaso, média de cinco plantas, nos três capins submetidos a doses de fósforo, por ocasião do segundo corte.

\begin{tabular}{|c|c|c|c|}
\hline \multirow{2}{*}{$\begin{array}{c}\text { Fósforo } \\
\mathrm{mg} / 1\end{array}$} & \multicolumn{3}{|c|}{ Capins } \\
\cline { 2 - 4 } & IZ-1 & brizantha & decumbens \\
\hline 3,1 & $14,00 \mathrm{cA}$ & $13,00 \mathrm{bA}$ & $14,50 \mathrm{cA}$ \\
\hline 15,5 & $24,00 \mathrm{bB}$ & $33,00 \mathrm{aA}$ & $30,50 \mathrm{bAB}$ \\
\hline 31,0 & $30,00 \mathrm{aB}$ & $36,75 \mathrm{aAB}$ & $40,00 \mathrm{aA}$ \\
\hline
\end{tabular}

C.V. $=10,6 \%$

DMS - Tukey a $5 \%$ para média das espécies e das doses $=2,84$

Letras maísuculas diferentes em cada linha e letras minúsculas diferentes em cada coluna, indicam diferença significativa ao nível de $5 \%$ de probabilidade.

$\mathrm{O}$ número de perfilhos aumentou com a elevação das doses crescentes de fósforo, exceto para a brizantha da dose 15,5 para a dose 31,0 $\mathrm{mg} / \mathrm{l}$. Também, em geral, o número de perfilhos foi maior no segundo crescimento das forrageiras. Segundo WERNER ( 1986), o fósforo apresenta grande influência no perfilhamento das plantas. 


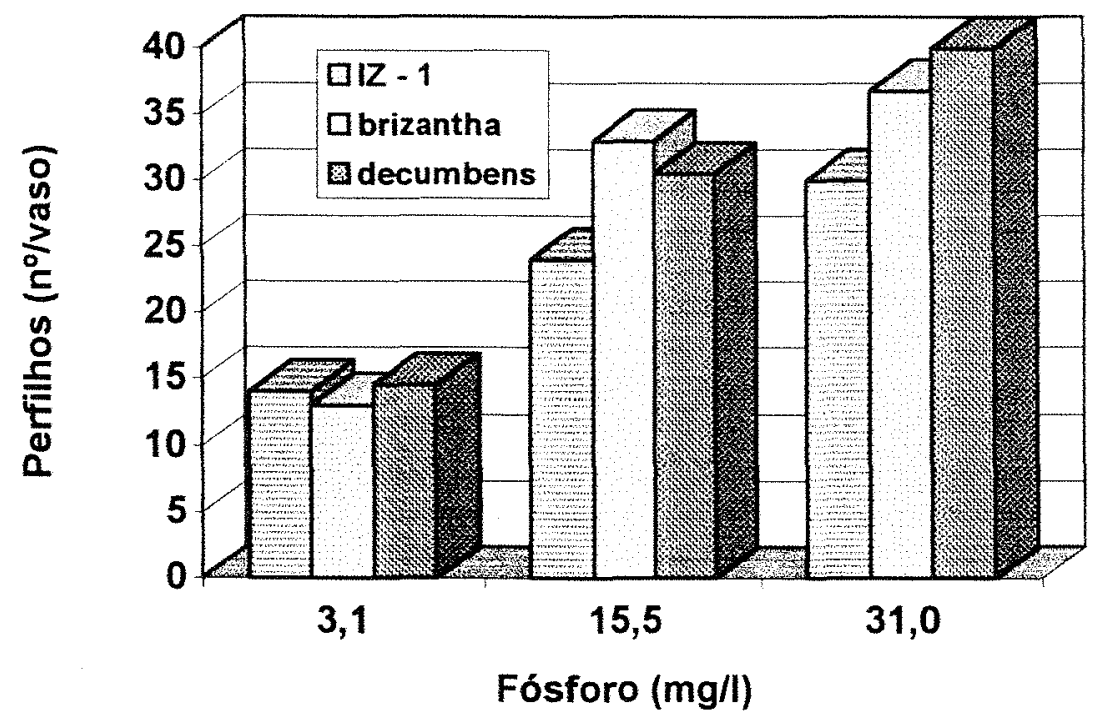

Figura 23. Número de perfilhos por vaso, em cinco plantas, com três espécies forrageiras submetidas a dose de fósforo, por ocasião do segundo corte.

\subsubsection{Produção de matéria seca da parte aérea e das raízes}

A produção de matéria seca da parte aérea das espécies estudadas sofreu incrementos significativos $(\mathrm{P}<0,05)$ como mostra a tabela 23.

O Panicum maximum apresentou produção de matéria seca da parte aérea maior que o da Brachiaria decumbens, não diferindo, entretanto, da Brachiaria brizantha. ARAGÃO et al. (1981) observaram, em solo Podzólico Vermelho - Escuro, melhor resposta na produção de matéria seca 
para o Panicum maximum quando comparado com as braquiárias brizantha e decumbens.

Tabela 23. Produção de matéria seca (g/vaso) e concentração de fósforo na parte aérea ( \%), em cinco plantas, nos três capins, submetidas a doses de fósforo na solução nutritiva, por ocasião do segundo corte.

\begin{tabular}{|c|c|c|}
\hline Capins & $\begin{array}{c}\text { Matéria seca da parte } \\
\text { aérea } \\
(\mathrm{g} / \mathrm{vaso})\end{array}$ & $\begin{array}{c}\text { Teor de fósforo da parte } \\
\text { aérea }(\%)\end{array}$ \\
\hline $\mathrm{IZ}-1$ & $14,22 \mathrm{~A}$ & $0,12 \mathrm{~A}$ \\
\hline brizantha & $13,73 \mathrm{AB}$ & $0,11 \mathrm{~A}$ \\
\hline decumbens & $12,84 \mathrm{~B}$ & $0,10 \mathrm{~A}$ \\
\hline C.V. $(\%)$ & 12,7 & 16,6 \\
\hline
\end{tabular}

DMS - Tukey a $5 \%$ média de espécies e doses para matéria seca e concentração da parte aérea, respectivamente $=1,42 \mathrm{e} 0,02$

Letras diferentes dentro de cada coluna indicam diferenças significativas ao nível de $5 \%$ de probabilidade.

Para as doses de fósforo na solução houve aumento significativo na produção de matéria seca com as doses estudadas, e esse aumento ficou evidente na linearidade da resposta, como mostra a figura 24.

Os resultados evidenciaram que as espécies podem responder a doses mais altas de fósforo na solução, que as estudadas no presente trabalho. MARTINEZ \& HAAG (1980) e FURLANI \& USBERTI FILHO (1990), trabalhando com capim-colonião, constataram respostas expressivas na 
produção de matéria seca com o aumento nas doses de fósforo. ARAGÃO et al. (1981) evidenciou estas respostas para as braquiárias.

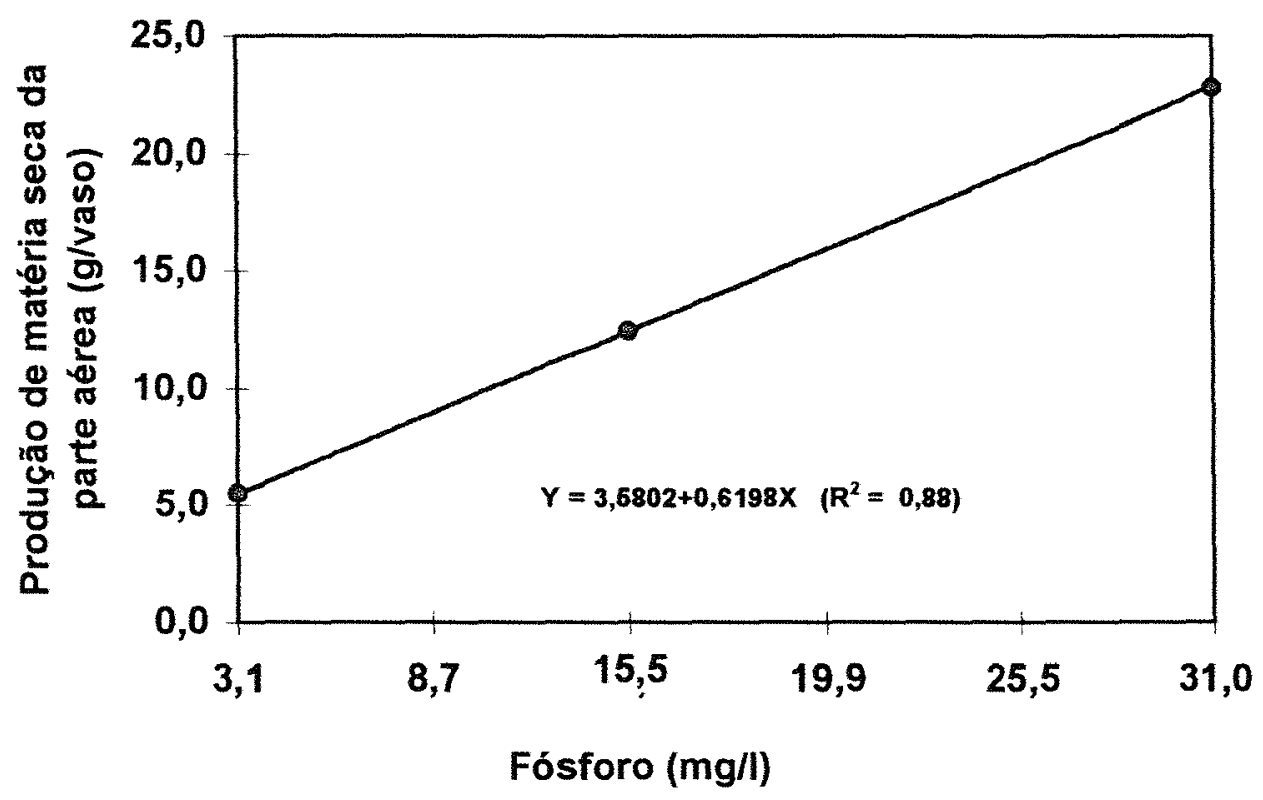

Figura 24. Produção de matéria seca da parte aérea (g/vaso) em cinco plantas, das três espécies forrageiras submetidas a doses de fósforo, por ocasião do segundo corte das plantas.

Para a produção de matéria seca das raizes verificou-se interação significativa entre as epécies e as doses de fósforo aplicadas, como mostra a tabela 24 .

O IZ-1 obteve maior produção de matéria seca das raízes, quando comparado com a decumbens nas duas maiores doses de fósforo $(15,5$ e $31,0 \mathrm{mg} / 1)$. As braquiárias diferiram apenas na dose mais alta 
(31,0 mg/1 ), sendo que a brizantha apresentou maior produção que a decumbens.

Houve um aumento na produção de matéria seca das raizes, conforme o aumento nas doses de fósforo na solução para o IZ-1 e a brizantha, conforme mostra a figura 25 .

Tabela 24. Produção de matéria seca das raizes (g/vaso), média de cinco plantas, em três capins submetidos a doses de fósforo na solução nutritiva, por ocasião do segundo corte.

\begin{tabular}{|c|c|c|c|}
\hline \multirow{2}{*}{$\begin{array}{c}\text { Fósforo } \\
\mathrm{mg} / 1\end{array}$} & \multicolumn{3}{|c|}{ Capins } \\
\cline { 2 - 4 } & $\mathrm{IZ}-1$ & brizantha & decumbens \\
\hline 3,1 & $1,99 \mathrm{cA}$ & $1,89 \mathrm{cA}$ & $1,94 \mathrm{bA}$ \\
\hline 15,5 & $9,81 \mathrm{bA}$ & $8,10 \mathrm{bAB}$ & $6,10 \mathrm{aB}$ \\
\hline 31,0 & $12,26 \mathrm{aA}$ & $10,89 \mathrm{aA}$ & $7,09 \mathrm{aB}$ \\
\hline
\end{tabular}

C.V. $=15,8 \%$

DMS - Tukey a $5 \%$ para média das espécies e das doses $=1,08$

Letras maiúsculas diferentes em cada linha e letras minúsculas diferentes, em cada coluna indicam diferença significativa ao nível de $5 \%$ de probabilidade.

As equações demonstram um efeito quadrático das respostas com as espécies para as doses de fósforo, apresentando respostas as doses estudadas. 


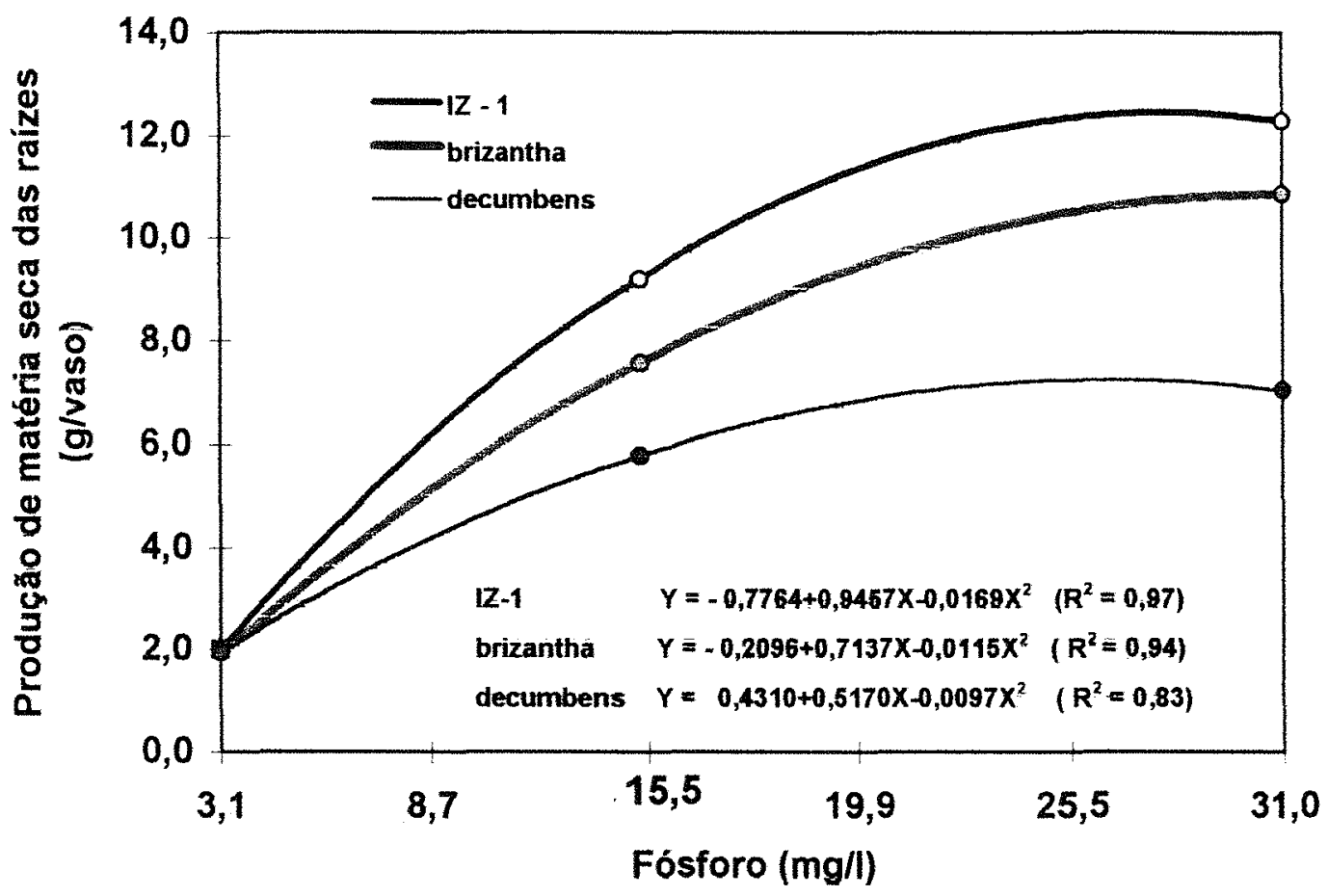

Figura 25. Produção de matéria seca das raízes ( $g$ /vaso), em cinco plantas, de três espécies forrageiras submetidas às doses de fósforo, por ocasião do segundo corte.

\subsubsection{Teor de fósforo da parte aérea e das raízes}

Os teores de fósforo tanto da parte aérea quanto das raizes não mostraram significância para as espécies, como mostra a tabela 25 .

Os teores de fósforo da parte aérea apresentaram valores absolutos mais elevados que das raízes, caracterizando o transporte de fósforo dentro das plantas. FURLANI \& USBERTI FILHO (1990) relataram acentuado transporte de fósforo, das raizes para a parte aérea, em trabalho com vários genótipos de Panicum maximum. 
Tabela 25. Teor de fósforo ( $\%$ ) da parte aérea e das raízes, em cinco plantas, de três capins submetidas a doses de fósforo, por ocasião do segundo corte.

\begin{tabular}{|c|c|c|}
\hline \multirow{2}{*}{ Capins } & \multicolumn{2}{|c|}{ Concentração de Fósforo (\%) } \\
\cline { 2 - 3 } & parte aérea & raízes \\
\hline IZ -1 & $0,10 \mathrm{~A}$ & $0,08 \mathrm{~A}$ \\
\hline brizantha & $0,12 \mathrm{~A}$ & $0,08 \mathrm{~A}$ \\
\hline decumbens & $0,11 \mathrm{~A}$ & $0,08 \mathrm{~A}$ \\
\hline C.V. $(\%)$ & 16,6 & 13,9 \\
\hline
\end{tabular}

DMS - Tukey a $5 \%$ média das espécies e das doses para teor de fósforo da parte aérea e das raizes, respectivamente $=0,02$ e 0,01

Letras maiúsculas iguais dentro de cada coluna, indicam que não há diferença significativa ao nivel de $5 \%$ de probabilidade.

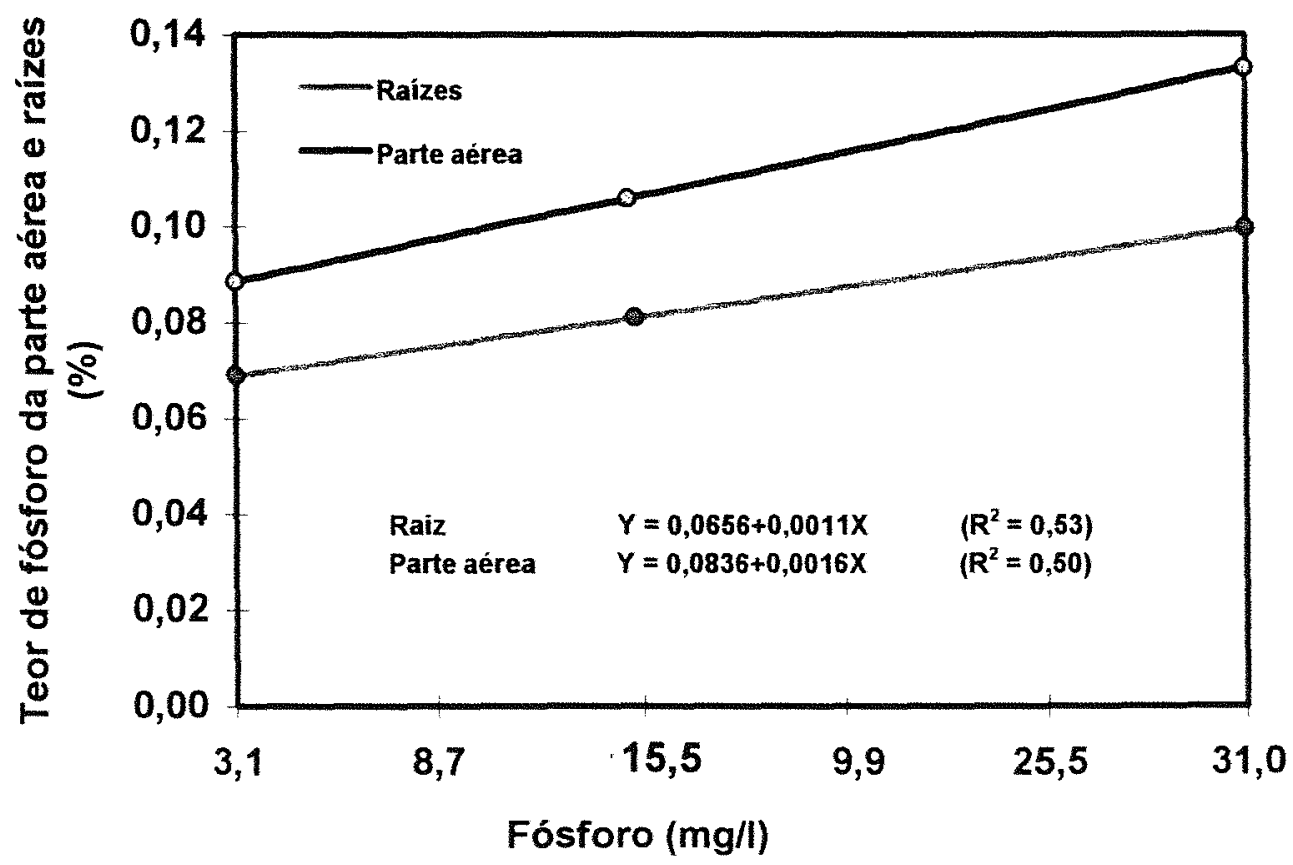

Figura 26. Teor de fósforo ( $\%$ ) da parte aérea, em cinco plantas das três espécies forrageiras submetidas a doses de fósforo, por ocasião do segundo corte. 
A Figura 26 mostra aumentos lineares para a concentração de fósforo na parte aérea e nas raízes, mostrando resposta à absorção para as doses de fósforo estudadas.

\subsubsection{Conteúdo de fósforo da parte aérea e das raízes}

O conteúdo de fósforo da parte aérea apresentou diferença significativa entre as espécies estudadas. Os valores estiveram muito próximos entre si, ou seja $16,97 \mathrm{mg} /$ vaso para o IZ-1, 16,63 mg/vaso para a brizantha e $15,32 \mathrm{mg} /$ vaso para a decumbens.

Para doses de fósforo na solução, a variação no conteúdo de fósforo na parte aérea foi significativa $(\mathrm{P}<0,05)$ como mostra a figura 27. A equação representa um efeito linear, como resposta no conteúdo de fósforo nas forrageiras, em relação às doses de fósforo estudadas.

A interação entre as espécies e as doses de fósforo foi significativa para o conteúdo de fósforo das raízes, como mostra a tabela 26. Os capins não diferiram entre si, para o conteúdo de fósforo, quando as plantas cresceram nas duas doses mais baixas de fósforo na solução. Entretanto, houve uma superioridade no conteúdo de fósforo na parte aérea do IZ-1 em relação à decumbens na dose mais alta do fósforo na solução.

Os valores mostram aumento de conteúdo de fósforo das raízes, conforme o aumento nas doses do nutriente na solução, para as espécies IZ-1, brizantha e decumbens, como ilustrado na figura 28. 
FURLANI \& USBERTI FILHO (1990) destacaram a eficiência de absorção e utilização do fósforo pelo Panicum maximum, quando testaram onze genótipos sob quatro níveis de fósforo, com aumento no conteúdo de fósforo nas folhas e das raizes das plantas.

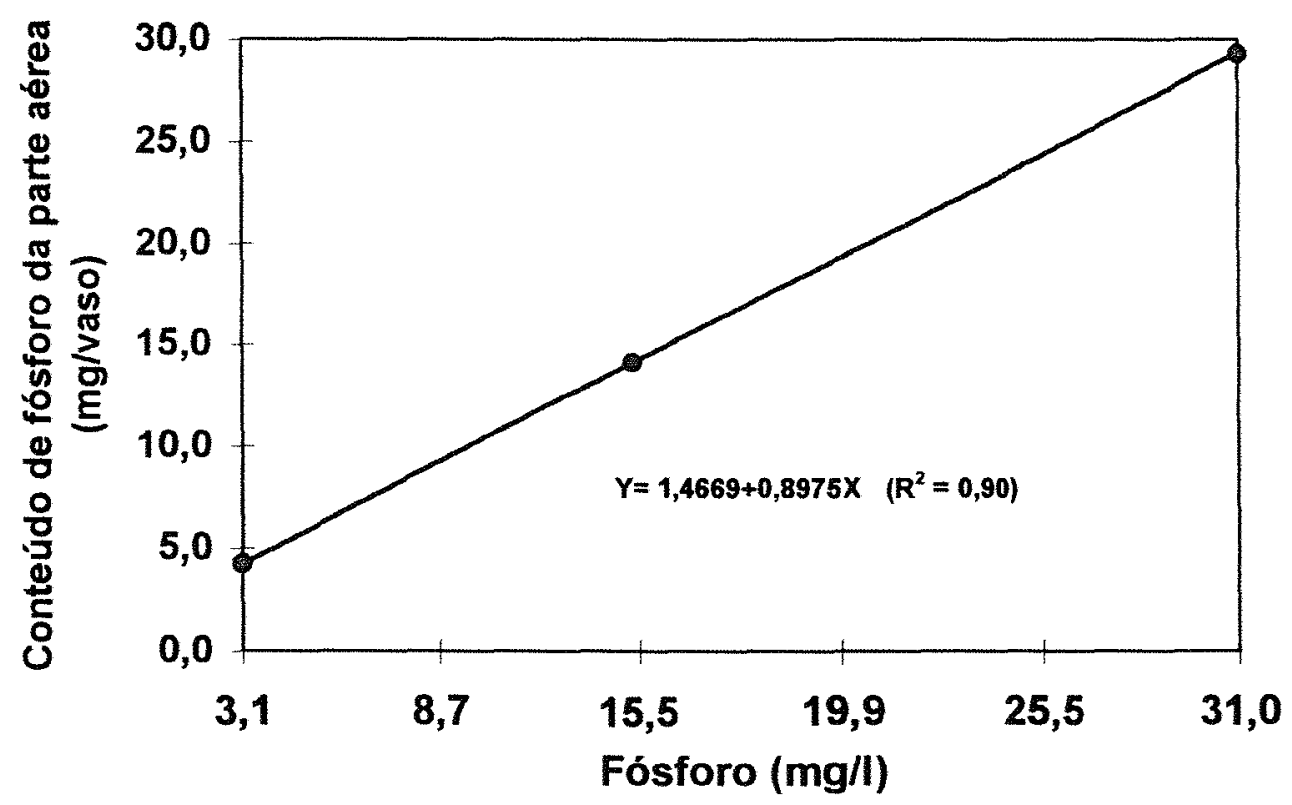

Figura 27. Conteúdo de fósforo da parte aérea( $\mathrm{mg} / \mathrm{vaso}$ ), em cinco plantas, três forrageiras submetidas às doses de fósforo, por ocasião do segundo corte. 
Tabela 26. Conteúdo de fósforo ( $\mathrm{mg} /$ vaso ) das raizes, média de cinco plantas, dos três capins submetidas a doses de fósforo na solução nutritiva, por ocasião do segundo corte.

\begin{tabular}{|c|c|c|c|}
\hline $\begin{array}{c}\text { Fósforo } \\
\mathrm{mg} / 1\end{array}$ & \multicolumn{3}{|c|}{ Capins } \\
\hline & IZ-1 & brizantha & decumbens \\
\hline 3,1 & $1,35 \mathrm{cA}$ & $1,36 \mathrm{cA}$ & $1,27 \mathrm{bA}$ \\
\hline 15,5 & $7,38 \mathrm{bA}$ & $6,08 \mathrm{bA}$ & $5,35 \mathrm{aA}$ \\
\hline 31,0 & $12,29 \mathrm{aA}$ & $10,71 \mathrm{aAB}$ & $7,08 \mathrm{aB}$ \\
\hline
\end{tabular}

C.V. $=23,6 \%$

DMS - Tukey a $5 \%$ para média das espécies e das doses $=1,41$

Letras maiúsculas diferentes em cada linha e letras minúsculas diferentes em cada coluna indicam diferença significativa ao nível de $5 \%$ de probabilidade.

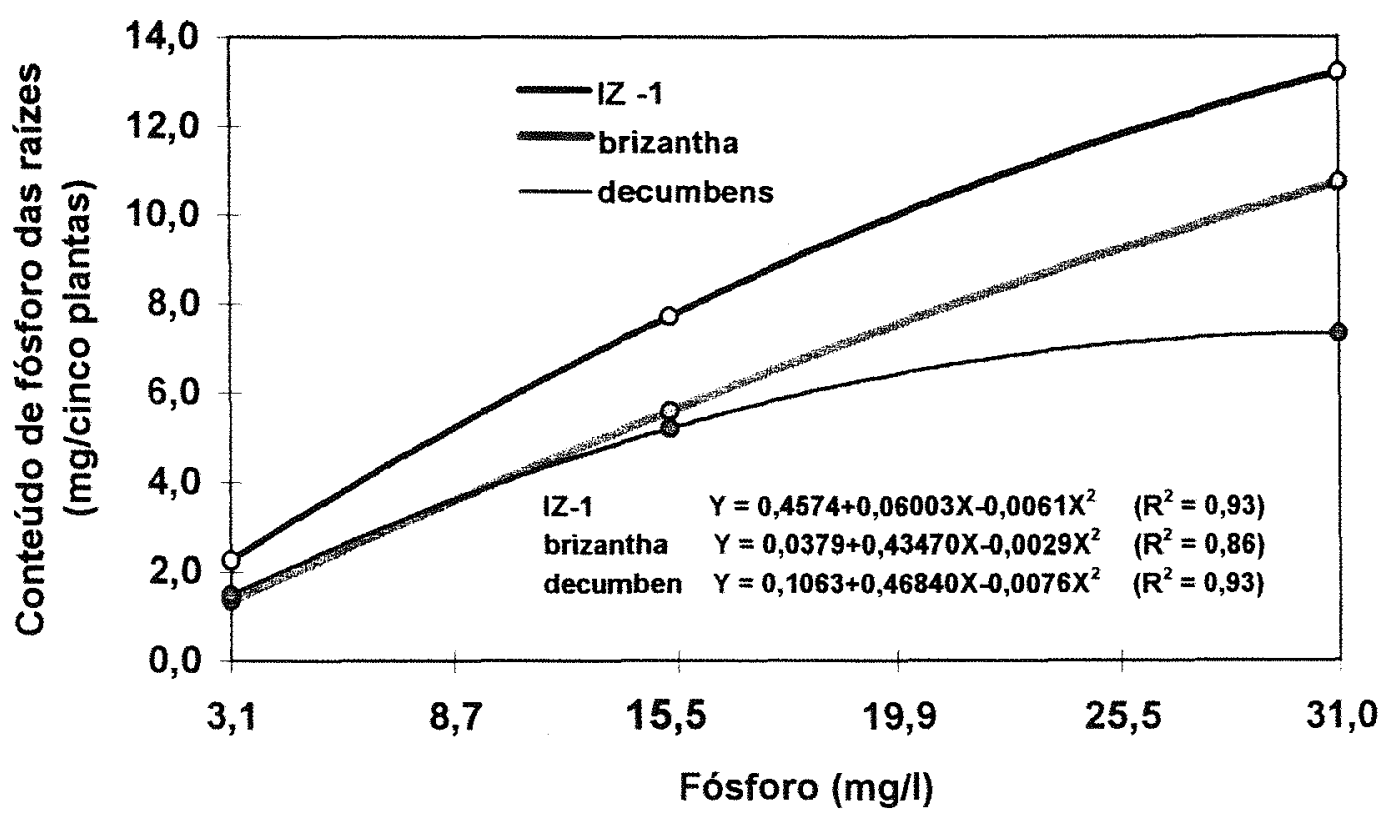

Figura 28. Conteúdo de fósforo nas raízes ( $\mathrm{mg} / \mathrm{vaso}$ ), em cinco plantas, de três gramíneas forrageiras submetidas a doses de fósforo, por ocasião do segundo corte. 


\subsubsection{Atividade de fosfatase ácida em tecido foliar}

A interação entre as espécies e as doses de fósforo estudadas foi significativa para a atividade de fosfatase ácida, como mostra a tabela 27.

Os resultados da atividade de fosfatase ácida foram estatisticamente similares entre as espécies, dentro de cada dose de fósforo na solução nutritiva. Provavelmente o intervalo de tempo em que as plantas foram submetidas à solução nutritiva, durante o período de rebrota, conduziu a esse resultado.

O experimento mostrou significância para a variação entre as doses de fósforo realçando a hidrólise do fósforo, ligado a substâncias orgânicas, não disponível no meio de crescimento, sendo liberado para as plantas conforme descrito por BIELESKI (1973) e BASSO \& SILVA (1992).

Tabela 27. Atividade de fosfatase ácida ( $\mu \mathrm{M} \mathrm{pNPP/h} / \mathrm{g}$ de matéria fresca), em cinco plantas, de três capins submetidas a doses de fósforo, por ocasião do segundo corte.

\begin{tabular}{|c|c|c|c|}
\hline \multirow{2}{*}{$\begin{array}{c}\text { Fósforo } \\
\mathrm{mg} / 1\end{array}$} & \multicolumn{3}{|c|}{ Capins } \\
\cline { 2 - 4 } & IZ-1 & brizantha & decumbens \\
\hline 3,1 & $72,42 \mathrm{aA}$ & $129,44 \mathrm{aA}$ & $122,92 \mathrm{aA}$ \\
\hline 15,5 & $38,15 \mathrm{bA}$ & $36,45 \mathrm{bA}$ & $42,05 \mathrm{bA}$ \\
\hline 31,0 & $32,59 \mathrm{bA}$ & $32,03 \mathrm{bA}$ & $32,76 \mathrm{bA}$ \\
\hline
\end{tabular}

C.V. $=25,1 \%$

DMS - Tukey a $5 \%$ para média das espécies e das doses $=15,29$

Letras maiúsculas diferentes em cada linha e letras minúsculas diferentes em cada coluna, indicam diferença significativa ao nível de $5 \%$ de probabilidade. 


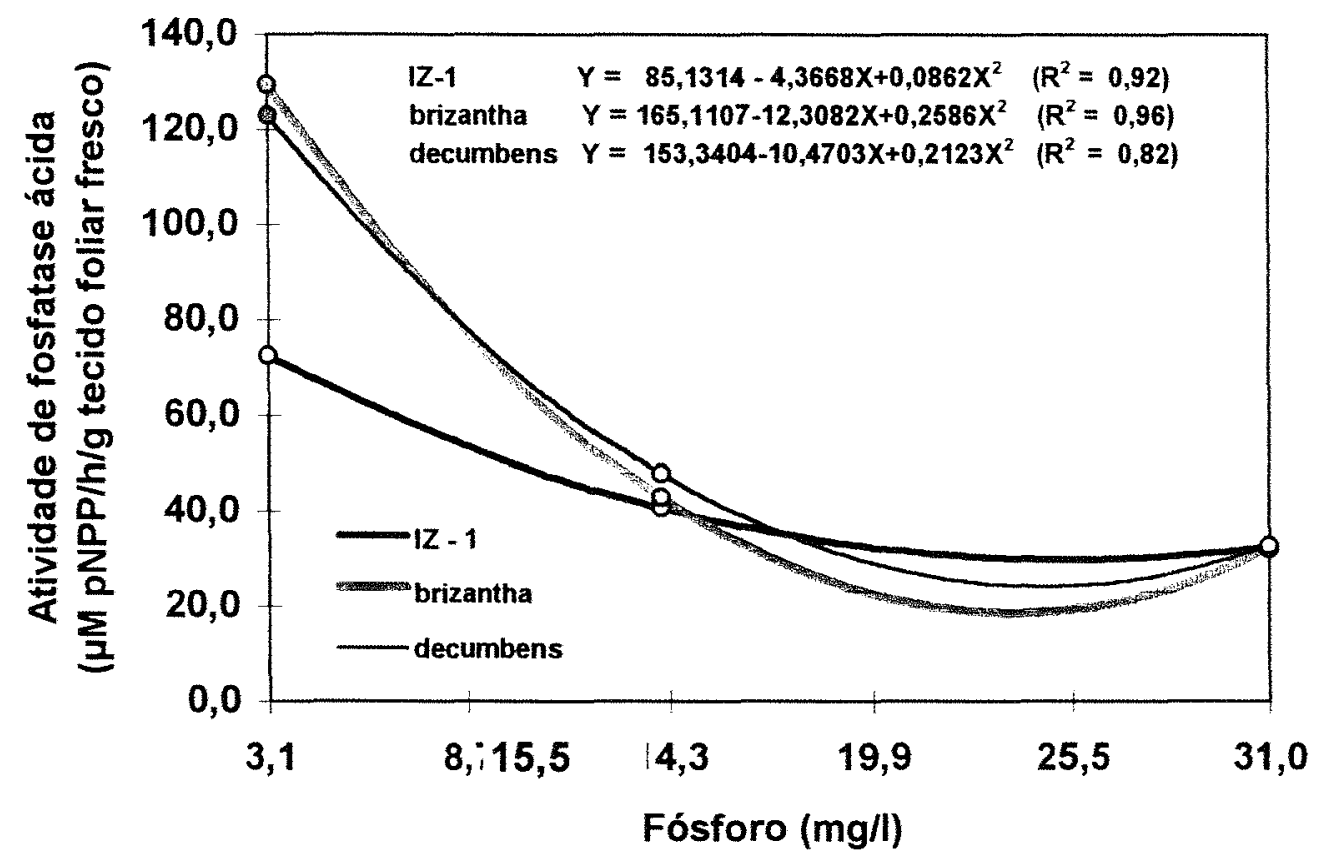

Figura 29. Atividade de fosfatase ácida $(\mu \mathrm{M} \mathrm{pNPP} / \mathrm{h} / \mathrm{g}$ de tecido foliar fresco), em cinco plantas, de três espécies forrageiras submetidas a doses de fósforo na solução nutritiva por ocasião do segundo corte.

Para as doses de fósforo na solução observou-se uma diminuição na atividade de fosfatase com o aumento nas doses de fósforo.

Quando considerada a correlação da produção de matéria seca da parte aérea com a atividade de fosfatase ácida, o IZ-1 apresentou o maior coeficiente de correlação $(r=-0,97)$ seguido pela decumbens $(r=-0,89)$ e finalmente pela brizantha $(r=-0,87)$. Para a correlação do teor de fósforo com essa atividade enzimática o Panicum maximum também apresentou o maior coeficiente $(r=-0,86)$, sendo seguido pelas braquiárias decumbens e brizantha $(r=-0,77)$ e $(r=-0,72)$ respectivamente. Para os teores de fósforo na solução 
nutritiva os coeficientes de correlação com a atividade enzimática foram $r=-0,82$ para o IZ-1, $r=-0,79$ para a brizantha $\mathrm{r}=-0,78$ para a decumbens. A correlaçào da atividade dessas enzimas com o número de perfilhos também mostrou elevados coeficientes, sendo que o IZ-1 apresentou o maior valor $(r=-0,97)$ e foi seguido pela brizantha $(r=-0,95)$ e pela decumbens $(\mathrm{r}=-0,92)$.

As correlacões apresentaram coeficientes negativos, caracterizando uma relação inversa da atividade de fosfatase ácida para os parâmetros produção de matéria seca, de teor de fósforo no tecido vegetal e do número de perfilhos e das doses de fósforo na solução nutritiva.

O Panicum maximum mostrou melhores correlações com os parâmetros avaliados, demonstrando boas respostas em termos de fósforo nas plantas. 


\section{CONCLUSÕES}

Nas condições em que foi desenvolvido o presente trabalho, os resultados obtidos permitem apresentar as seguintes conclusões:

- A atividade enzimática da fosfatase ácida da folha pode ser utilizada como um parâmetro para avaliar o estado nutricional das espécies forrageiras de Panicum maximum cv. IZ-1, Brachiaria brizantha cv. Marandu e Brachiaria decumbens, em relação ao fósforo.

- Os valores obtidos entre a atividade de fosfatase ácida mostraram relações inversas quanto ao número de perfilhos, produção de matéria seca e teor e conteúdo de fósforo nas plantas.

- A atividade de fosfatase ácida nas folhas das forrageiras decresceu com o incremento da dose de fósforo na solução nutritiva.

- O aumento nas doses de fósforo nas soluções nutritivas proporcionam aumentos em todos os parâmetros produtivos das forrageiras. 


\section{REFERÊNCIAS BIBLIOGRÁFICAS}

APPIAH, M. R. ; THOMAS, R. L. Inositol phosphatase and organic phosphorus contents and phosphatase activity of some Canadian and Ghanaian soils. Canadian Journal Soil Science, v.62, p.31-38, 1982.

APPIAH, M. R. Organic phosphorus and phosphatase activity in cocoa soils in Ghana. Journal of Agriculture Science Accra, v.8, p.45-50, 1975.

ARAGÃO, W.M.; ALMEIDA, S. A; SOBRAL, C. F.; BARRETO, A. C. Introdução e avaliação agronômica de gramíneas forrageiras no Estado de Sergipe. Aracaju: EMBRAPA/UEPAE, 1981. 8p.

ARROYO-AGUILU, J.A. ; COWARD-LORD, J. Mineral comparation of 10 tropical forage grasses. The Journal of the University of Puerto Rico, v. 58 , n.4 p.426-36, 1974.

BARRET-LENNARD, E.G. ; GREENWAY, H . Partial separation and characterization of soluble phosphatases from leaves of wheat grown under phosphorus deficiency and water deficity. Journal of Experimental Botany, v.33, n.135, p.694-704, 1982.

BASSO, J. C. ; SILVA, F. C. Avaliação da atividade "in vivo" da fosfatase ácida da folha na diagnose da nutrição fosfórica em cana-de-açúcar (Saccharum spp) In: REUNIÃO BRASILEIRA DE FERTILIDADE DO SOLO E NUTRIÇÃO DE PLANTAS, 20, Piracicaba-SP, 1992. Anais. Piracicaba-SP, Sociedade Brasileira de Ciência do Solo, 1992. p.152-3. 
BIELESKI, R. L. Phosphatase pools, phosphate transport and phosphate availability. Annual Review Plant Physiology, v.24, n.24, p.225-52, 1973.

BURANGULOVA, N. N. ; KHAZIEV, F. V. Nuclease activity of soils. [Rostlina Vyroba], Prague, v.11. n.6, p.579-84, 1965.

CLARK, R. B. ; BROWN, J. C. Differential phosphorus uptake by phosphorus stressed corn inbreds. Crop Science, v.14, p.505-8, 1974.

CORRÊA, L. A. Níveis críticos de fósforo para o estabelecimento Brachiaria decumbens Stapf, Brachiaria brizantha ( Hochst) Stapf cv. Marandu e Panicum maximum Jacq., em latossolo vermelho álico. Piracicaba, 1991. 83 p. Tese (Doutorado) - Escola Superior de Agricultura "Luiz de Queiroz", Universidade de São Paulo.

EPSTEIN, E. Nutrição mineral das plantas: princípio e perspectivas. Trad. de: E. Malavolta. Rio de Janeiro: LTC; São Paulo, EDUSP, 1975. 399 p.

FURLANI, A. M. C. ; USBERTI FILHO, J. A. Capim-colonião: Eficiência na absorção e na utilização de fósforo em solução nutritiva. Bragantia, v. 49, n.2, p. 413-23, 1990.

FURLANI, A. M. C. ; CLARK, R. B. ; MARANVILLE, J. W. ; ROSS, W. M. ROOT. Phosphatase activity of sorghum genotypes grow with organic and inorganic sources of phosphorus. Journal of Plant Nutrition, v.7. n.11, p.1583-95, 1984. 
GONÇALVES, C. A. ; OLIVEIRA, J. R. da C. Formação, recuperação e manejo de pastagens em Rondônia Porto Velho: UEPAE de Porto Velho, 1982. 22p. (Circular Técnico UEPAE).

MAlaVolta, E. Elementos de Nutrição Mineral de Plantas. São Paulo, Agronômica Ceres, p.130-40, 1980.

MARTINEZ, H.G. P. ; HAAG, H.P. Níveis críticos de fósforo em Brachiaria decumbens (STAPF) Prain, Brachiaria humidicola (RENDLE) schweickerdt Digitaria decumbens stent, Hyparrhenia rufa (Ness) Stapf, Melinis minu - tiflora Paul de Beauv, Panicum maximum Jacq. e Pennisetum purpureum Anais da Escola Superior de Agricultura "Luiz de Queiroz", v.37 p.913-77, 1980.

McLACHLAN, K.D. Comparative phosphorus in plants to a range of available phosphorus situations. Australian Journal of Agriculture Research, v.27, p.323-341, 1976.

McLACHLAN, K.D. ; DE MARCO, D. G. Acid phosphatase activity of intact roots and phosphorus nutrition in plants. III. Its relation to phosphorus garnering by wheat and comparation with leaf activity as measure of phosphorus status. Australian Journal of Agriculture Research, East Melbourne v.33, p.1-11, 1982.

MEIRELLES, N. M. F. ; WERNER, J. C. ; ABRAMIDES, P. L. G. ; CARRIEL, J. M. ; PAULINO, V. T. ; COLOZZA, M. T. Nível crítico de fósforo em capim-coloniăo cultivado em dois tipos de solo: Latossolo Vermelho-Escuro e Podzólico Vermelho-Amarelo. Boletim de Indústria Animal, v.45, n.1, p. 215-32, 1988. 
MONTEIRO, F.A. ; WERNER, J.C. Efeito das adubações nitrogenada e fosfatada em capim - colonião, na formação e em pasto estabelecido. Boletim de Indústria Animal, v.34, n.1, p.91-101, 1977.

MONTEIRO, F. A. ; RAMOS, A. K. B. ; CARVALHO, D. D. ; ABREU, J. B. R. , DAIUB, J. A. S. ; SILVA, J. E. P. ; NATALE, W. Cultivo de Brachiaria brizantha $\mathrm{cv}$ Marandu em solução nutritiva com omissão de macronutrientes. Scientia Agrícola, Piracicaba, v.52, p. 135-141, 1995.

MORIKAWAL, C.K. Limitações ntricionais para o Andropogon (Andropogon gayanus) e Braquiarão (Brachiaria brizantha) em latossolo da região dos Campos Vertentes - MG. Lavras, 1993. 136p. Dissertação (Mestrado) - Escola Superior de Agricultura de Lavras.

PALMA, M.S. ; TAUK, S .M. ; RAYMUNDO, JR. O. Atividade da fosfatase ácida em latossolo vermelho - amarelo, textura média, tratado com vinhaça no município de Corumbataí - SP. Revista Brasileira de Ciência do Solo, v.12, p. 7-10, 1988.

PEREIRA, J. P. Adubação de capins do gênero Brachiaria. In: ENCONTRO PARA DISCUSSÃO DOS CAPINS DO GÊNERO Brachiaria, Nova Odessa, 1986. Anais, editado por J.V.S. PEDREIRA; N.M.F. Meirelles. Nova Odessa: Instituto de Zootecnia, 1986.

RAIJ, B. VAN. Fertilidade do solo e adubação. São Paulo: Ceres; Piracicaba: Potafos, 1991. p.181-202.

SALINAS, J.G. ; SANCHEZ, P.A. Soil - plant relationships affecting varietal and species difference in tolerance to low avaible soil phosphorus. Ciência e cultura, São Paulo, v.28, n.2, p. 156-168, 1976. 
SARRUGE, J. R. ; HAAG, H. P. Análises em plantas. Piracicaba, ESALQ, $1974.56 \mathrm{p}$.

SARRUGE, J. R. Soluções nutritivas. Summa Phytopatologica, v.1, n.3, p. 231-33, 1975.

SERRÃO, E.A.S. ; SIMÃO NETO, M. Informações sobre duas espécies de gramíneas forrageiras do gênero Brachiaria na Amazônia: Brachiaria decumbens Stapf. e Brachiaria ruziziensis Germain et Everard. Belém: IPEAN, 1971. 31p. (IPEAN. Série Estudos sobre Forrageiras na Amazônia, 1, v.2).

VETORAZZO, S.C. Efeito de fatores do solo e genótipos no crescimento, nutrição e atividade da fosfatase ácida em clones de Eucaliptus grandis Hill Ex Maiden, Piracicaba, 1989, 115 p. Dissertação (Mestrado) Escola Superior de Agricultura "Luiz de Queiroz". Universidade de São Paulo.

WERNER, J. C. Estudos sobre a nutrição mineral de alguns capins tropicais. Piracicaba, 1971. 95p. Tese ( Doutorado) - Escola Superior de Agricultura "Luiz de Queiroz", Universidade de São Paulo.

WERNER, J. C. Adubação de pastagens. Nova Odessa: Instituto de Zootecnia, 1986. 49p. (Boletim Técnico, 18).

WERNER, J.C. ; MATTOS, H.B. Estudo de nutrição de capim gordura. Boletim de Indústria Animal, v.28, n.1, p. 175-84, 1972.

WERNER, J. C. ; QUAGLIATO, J. L. ; MARTINELLI, D. Ensaio de fertilização do colonião da "Noroeste". Boletim de Indústria Animal, v.24, p. 159-67, 1967. 
ZAINI, Z. \& MERCADO, B.T. Phosphorus nutrition and phosphatase activity of young rice plants grown in culture solution. I. Levels of phosphorus and phosphatase activity of the roots. Phillipine Agricultural Review, v.68, n. 2, p.211-6, 1985. 